Stoichiometry of the net ecosystem metabolism in a coastal inlet affected by upwelling. The Ría de Arousa (NW Spain)

Fíz F. Pérez $^{\mathrm{a}, *}$, X.A. Álvarez-Salgado ${ }^{\mathrm{a}}$ and Gabriel Rosón ${ }^{\mathrm{b}}$

${ }^{\mathrm{a}}$ Instituto de Investigacións Mariñas, C.S.I.C. Eduardo Cabello 6, Vigo 36208, Spain

${ }^{\mathrm{b}}$ Facultad Ciencias del Mar, Universidad de Vigo, Apartado 874, Vigo 36200, Spain

Submitted to: Marine Chemistry

*Corresponding author. Email: fiz@iim.csic.es 
Abstract. The net uptake of inorganic carbon and nitrogen, phosphate and silicate and the net production of dissolved oxygen and organic carbon, nitrogen and phosphorus have been examined in the Ría de Arousa, a large coastal embayment in the NW Iberian upwelling system. Fluxes and net budgets were estimated with a non-stationary 2-D box model (Rosón et al., 1997) and the distributions of the different species acquired twice a week between May and October 1989 (Rosón et al., 1995). High N/P and N/Si net uptake ratios of 21 and 3.2 were observed during the upwelling season. The rapid recycling of phosphorus compared to nitrogen and the recurrent succession from pioneer diatoms $(\mathrm{Si} / \mathrm{N} \sim 1)$ to red-tide forming species $(\mathrm{Si} / \mathrm{N}=0)$ following the periodic upwelling pulses are the reasons behind the observed ratios. The molar ratios of dissolved oxygen production to inorganic carbon $(-1.48)$ and nitrogen uptake (-10.2) during the upwelling season agree with the Redfield stoichiometry. On the contrary, net nutrient regeneration occurred with $\mathrm{N} / \mathrm{P}, \mathrm{N} / \mathrm{Si}$ and $\mathrm{O}_{2} / \mathrm{C}$ ratios of $7.4,1.0$ and -1.02 during an intense autumn downwelling event. These low ratios are due to the release of an excess of phosphate, silicate and $\mathrm{CO}_{2}$ from the sediments. Conversely, the production of inorganic nitrogen is associated to the consumption of dissolved oxygen following a Redfield ratio of -10.0 . Whereas the $\mathrm{C} / \mathrm{N}$ ratio of the suspended organic matter produced during the upwelling season and consumed during the autumn downwelling event is 6.3-6.7, the N/P ratio changes from 11 during the upwelling season to 15 during the autumn downwelling. About 1/5 of the dissolved oxygen produced during the upwelling season and consumed during the autumn downwelling is delivered to and came from the atmosphere, respectively. Despite the $\mathrm{C} / \mathrm{N} / \mathrm{P} / \mathrm{O}_{2}$ ratios differ from the Redfield values, the high correlation between nutrient salts consumption and dissolved oxygen production $\left(r^{2}=0.74-0.86\right)$ allow to estimate an average net ecosystem production (NEP) from the individual elements. The 3-4 d time-scale variability of the average NEP depends on the two week periodicity of upwelling pulses, the heat exchange across the sea surface and the stability of the water column. As much as $70 \%$ of the total variability can be explained with a linear combination of these parameters. 
Keywords: Nutrients, $\mathrm{CO}_{2}$, net ecosystem production, upwelling, downwelling, Rías Baixas

(NW Iberian upwelling system)

\section{Glossary of terms}

$C_{\mathrm{i}}$

$C_{\mathrm{L}}, C_{\mathrm{U}}$

$C_{\mathrm{R}}$

$C_{\mathrm{T}}$

$D$

$F_{\mathrm{CO} 2}, F_{\mathrm{O} 2}, F_{\mathrm{Q}}$

$F_{\mathrm{E}}$

$F_{\mathrm{Qi}}$

$F_{\mathrm{R}}$

$i-o$

$I-O$

$I_{W}$

$K_{\mathrm{CO} 2}, K_{\mathrm{O} 2}$

$\mathrm{M}_{\mathrm{Z}}$

$B V$

NEP

$<N E P>$

$N_{\mathrm{T}}$

$<P O C>$

$Q_{\mathrm{X}}, Q_{\mathrm{X} 0}, Q_{\mathrm{Z}}$

$Q_{\mathrm{E}}$

$Q_{\mathrm{R}}, P, E$

$R_{\mathrm{C}}, R_{\mathrm{N}}, R_{\mathrm{P}}$

$\Delta$ Chl a

$\Delta C_{\mathrm{TCOR}}$

$\triangle \mathrm{CaCO}_{3}$

$\Delta N_{\mathrm{T}}$

$\Delta O_{2 \mathrm{COR}}$

$\Delta P$

$\Delta S i$

$\triangle P O C, \triangle P O N, \triangle P O P$

$\triangle T A$
Concentration of any species in a convective flow $\left(Q_{\mathrm{x}}, Q_{\mathrm{x} 0}, Q_{\mathrm{z}}\right)$

Concentration of any species in the lower and upper layer of the Ría

Concentration of any species in the river flow $\left(Q_{R}\right)$

Total inorganic carbon concentration

Flux of any species carried by the turbulent diffusion flow $\left(M_{\mathrm{Z}}\right)$

$\mathrm{CO}_{2}, \mathrm{O}_{2}$ and heat fluxes across the sea surface

Flux of any species associated to the 'boundary movement' $\left(Q_{E}\right)$

Flux of any species carried by a convective flow $\left(Q_{\mathrm{X}}, Q_{\mathrm{x} 0}, \mathrm{Q}_{\mathrm{z}}\right)$

Flux of any species carried by the river flow $(R)$

Net daily budget of inputs minus outputs in a box for any species

Average $i$ - $o$ between two consecutive surveys

Upwelling index

Piston velocities for $\mathrm{O}_{2}$ and $\mathrm{CO}_{2}$

Turbulent diffusion flow

Average depth-integrated Brunt-Väisälä frequency

Net ecosystem production, primary production minus community respiration

Average NEP from $\Delta \mathrm{C}_{\mathrm{TCOR}}, \Delta N_{\mathrm{T}}, \Delta \mathrm{P}$ and $\Delta \mathrm{O}_{\mathrm{T} 2 \mathrm{COR}}$

Total inorganic nitrogen (nitrate + nitrite + ammonia) concentration

Average particulate organic matter production from $\triangle P O C, \triangle P O N$ and $\triangle P O P$

Horizontal (upper and lower) and vertical convective flows

Net upward movement of the boundary between upper and lower layer

River flow, precipitation and evaporation rates

$\mathrm{O}_{2}$ production to $\mathrm{C}_{\mathrm{T}}, \mathrm{N}_{\mathrm{T}}$ and $\mathrm{P}$ consumption ratios

Net chlorophyll a production

$\mathrm{CaCO}_{3}$ corrected net $\mathrm{C}_{\mathrm{T}}$ production

Net calcium carbonate fixation

Net $N_{\text {T }}$ production

Ammonia and nitrite corrected net oxygen production

Net phosphate production

Net silicate production

Net particulate organic carbon, nitrogen and phosphorus production

Net total alkalinity production 


\section{Introduction}

The synthesis of the organic tissues of marine phytoplankton in the photic layer of the World Ocean is deeply associated with the consumption of nutrient salts and the production of dissolved oxygen (Redfield et al., 1963). The pioneer $-\mathrm{O}_{2} / \mathrm{C} / \mathrm{N} / \mathrm{P}$ Redfield numbers of 138/106/16/1 have been recently revisited (Anderson, 1995; Fraga et al., 1998), after revision of the biogeochemical composition of marine phytoplankton (Fraga and Pérez, 1990; Laws, 1991). $\mathrm{O}_{2} / \mathrm{CO}_{2} /$ nutrients data have been used to infer the composition of the phytogenic material by examining the resultant stoichiometric ratios during its aerobic oxidation at depth (Takahashi et al., 1985; Minster and Boulahdid, 1987; Anderson and Sarmiento, 1994). However, the stoichiometric ratios obtained from the phytoplankton biochemical composition and from the $\mathrm{O}_{2} / \mathrm{CO}_{2} /$ nutrients data in the upper ocean are not equivalent but complementary. The differences will depend on the relative importance of recycling processes (Sambrotto et al., 1993).

The ratios of nutrient consumption and organic matter production in a given zone are determined by: 1) the actual phytoplankton biochemical composition, which results from the production of primary metabolites in some proportions (Fraga and Pérez, 1990; Laws, 1991; Anderson, 1995, Fraga et al. 1998); and 2) the subsequent utilisation by a particular community of organisms. The disparity between consumption and production intensifies in coastal upwelling regions due to enhanced primary and secondary production rates and acute pelagic and benthic mineralization processes (Rowe et al., 1975; Walsh, 1991; Wollast, 1991; 1993; Christensen, 1994).

The western coast of the Iberian Peninsula experiences upwelling favourable winds during the spring and summer (Wooster et al., 1976; Blanton et al., 1987). In addition to the upwelling of Eastern North Atlantic Central Water (ENACW), the nutrient condition of shelf waters is affected by the organic matter outwelled from the 'Rías Baixas', four large V-shaped coastal indentations (Fraga, 1981; Tenore et al., 1982; 1995; Álvarez-Salgado 1993; 1997). Coastal upwelling forces a 2-D circulation pattern along the main axis of the rías (Otto, 1975). 
The circulation is positive during upwelling events and reversed during the subsequent upwelling relaxations, or under downwelling conditions (Rosón et al., 1997). Nutrients transported by upwelled ENACW into the rías are consumed there at high rates, and part of the produced organic matter is exported to the adjacent shelf (Prego 1994; Rosón et al., 1995; Álvarez-Salgado, 1996a; Doval et al. 1997). As a consequence, extensive accumulation of organic matter (López-Jamar et al., 1992) and opal (Prego and Bao, 1997) occurs in pelagic sediments off the rías.

An intensive research programme was conducted in the Ría de Arousa (NW Spain) and the adjacent shelf from May to October 1989 to quantify the short-time-scale variability on the fluxes of some selected biogeochemical species. The qualitative studies of AlvarezSalgado et al. (1993) and Rosón et al. (1995) demonstrated the key contribution of wind-driven upwelling/downwelling events to the observed distributions of physical and biogeochemical variables either in the Ría and the shelf. The short-time-scale hydrographic variability imposed by the periodic ( $\sim 2$ wk) succession of upwelling/downwelling events precludes the application of the stationary box-model approach to calculate water flows. Therefore, Rosón et al. (1997) developed a 2-D non-stationary mass-heat weighted box-model to calculate water flows in the Ría de Arousa. The calculated flows were positively correlated $(r=+0.67)$ with the Ekman transport, showing enhanced positive circulation during upwelling and reversed circulation during upwelling relaxation and downwelling. Knowledge of water flows allowed Álvarez-Salgado et al. (1996a, 1996b) and Rosón et al. (1999) to set the spatial and short-time-scale variability in the fluxes and net budgets of nitrogen and carbon species. They observed that the net ecosystem production (NEP) of carbon and nitrogen were linked to the Ekman transport, with maximum values after strong upwelling events supported by external nitrate and minimum values after periods of prolonged relaxation, when ammonium accumulated in the Ría. The culture of mussels on hanging ropes - the most intensive over world (Tenore et al. 1982) — had a major impact on carbon and nitrogen biogeochemistry, enhancing the formation of dissolved organic matter. During the 
upwelling season, total inorganic carbon trapped in the Ría (average, $0.95 \mathrm{~g} \mathrm{C} \mathrm{m}^{-2} \mathrm{~d}^{-1}$ ) was distributed between organic (88\%, NEP) and inorganic $\left(12 \%, \mathrm{CaCO}_{3}\right)$ forms. The NEP was mainly exported to the shelf as particulate (25\%) and dissolved (58\%) organic carbon. Carbon and nitrogen biogeochemistry was deeply affected by the strong autumn downwelling event of late October 1989. Net regeneration was dominant all over the Ría (average $-0.66 \mathrm{~g} \mathrm{C} \mathrm{m}^{-2} \mathrm{~d}^{-1}$ ), with an intense release of $\mathrm{CO}_{3} \mathrm{H}^{-}$and $\mathrm{NH}_{4}{ }^{+}$from the sediments (average $0.53 \mathrm{~g} \mathrm{C} \mathrm{m}^{-2} \mathrm{~d}^{-1}$ and $0.10 \mathrm{~g} \mathrm{~N} \mathrm{~m}^{-2} \mathrm{~d}^{-1}$, respectively).

Once the carbon and nitrogen biogeochemistry of the Ría de Arousa during the upwelling season 1989 have been studied in detail, we plan to extend our 2-D non-stationary box-model approach to calculate the NEP of phosphorus, silicon and dissolved oxygen in the present complementary work. Our main objectives here are two. 1) to study the $\mathrm{O}_{2} / \mathrm{C} / \mathrm{N} / \mathrm{P} / \mathrm{Si}$ stoichiometry of the NEP in the Ría de Arousa: how the hydrography affects the deviations from the Redfield ratios?. And 2) to predict the $\mathrm{O}_{2} / \mathrm{C} / \mathrm{N} / \mathrm{P}$ average NEP rates in the Ría de Arousa from the external physical forces acting on the system: could the NEP of a coastal inlet affected by wind-driven upwelling be parametrised using only physical and meteorological variables?

\section{Material and methods}

\subsection{Sampling programme}

Data used in this work were collected from 5 to 7 depths at 10 fixed stations distributed all over the Ría de Arousa (Fig. 1). This programme was repeated 46 times from 12 May to 30 October 1989, which means a survey every 3-4 days. The surface area and volume bounded by stns $1,7,8$ and 10 are $182.4 \mathrm{Km}^{2}$ and $4.203 \mathrm{Km}^{3}$. The remaining $48.5 \mathrm{Km}^{2}$ and $0.060 \mathrm{Km}^{3}$ comprise the innermost part of the ría: the estuaries of the rivers Ulla and Umia. Salinity, dissolved oxygen, 5-nutrients, $\mathrm{pH}$, total alkalinity (TA), chlorophyll and particulate organic matter (carbon, nitrogen and phosphorous) were determined by the methods described in Rosón et al. (1995) and Álvarez-Salgado et al. (1996a). Total inorganic carbon $\left(\mathrm{C}_{\mathrm{T}}\right)$ and 
partial pressure of $\mathrm{CO}_{2}$ at the sea surface $\left(\mathrm{pCO}_{2}\right)$ were calculated from $\mathrm{pH}$ and TA with the equations of the thermodynamic equilibrium of the $\mathrm{CO}_{2}$ system. In addition, daily data of wind over the shelf, river flows $\left(Q_{R}\right)$, and precipitation rates $(P)$ were obtained from the Meteorological observatory at Cape Finisterre, the gauge stations at the rivers Ulla and Umia and the meteorological observatory at Vilagarcía de Arousa, respectively.

\subsection{Variables derived from collected data}

The Ekman transport $\left(I_{\mathrm{W}}\right.$, in $\left.\mathrm{m}^{2} \mathrm{~s}^{-1}\right)$ was calculated from Cape Finisterre wind data following the method of Bakun (1973). The evaporation (E) was obtained with the empirical formulae of Otto (1975) for the Ría de Arousa. The heat exchange flux across the sea surface $\left(F_{\mathrm{Q}}\right)$ was evaluated with the Mosby's formulae (Sverdrup et al., 1942), considering the cloudiness, the back radiation and the evaporation rates (Rosón et al., 1997).

Carbon and dissolved oxygen budgets must include $\mathrm{CO}_{2}$ and $\mathrm{O}_{2}$ exchange with the atmosphere. Following Woolf and Thorpe (1991), $\mathrm{CO}_{2}$ fluxes across the sea surface $\left(\mathrm{FCO}_{2}\right.$, in mol s${ }^{-1}$ ) were calculated by Rosón et al. (1999) using the equation:

$$
F_{\mathrm{CO}_{2}}=k_{\mathrm{CO}_{2}} \cdot S_{\mathrm{CO}_{2}} \cdot\left(p C \mathrm{O}_{2}-p \mathrm{CO}_{2 \mathrm{ATM}}\right) \cdot \mathrm{A}
$$

where $k \mathrm{CO}_{2}\left(\mathrm{~m} \mathrm{~s}^{-1}\right)$ is the piston velocity, $\mathrm{SCO}_{2}\left(\mathrm{~mol} \mathrm{l}^{-1} \mathrm{~atm}{ }^{-1}\right)$ is the solubility of $\mathrm{CO}_{2}$ in seawater (Weiss 1974), and $A$ is the surface area of the Ría de Arousa. Accordingly, oxygen fluxes $\left(\mathrm{FO}_{2}\right.$, mol s$\left.{ }^{-1}\right)$ were calculated in the present work with the following equation:

$$
F_{O_{2}}=k_{O_{2}} \cdot\left(O_{2 S A T}-O_{2}\right) \cdot A
$$

where $\mathrm{KO}_{2}\left(\mathrm{~m} \mathrm{~s}^{-1}\right)$ is the piston velocity for oxygen, calculated from local wind speed following Kester (1975) and $\mathrm{O}_{2 \mathrm{SAT}}$ is the oxygen concentration at saturation (UNESCO, 1985).

\subsection{Calculation of water flows and species fluxes with the 2-D box model}

Water flows were taken from Rosón et al. (1997). These authors estimated the upper $\left(Q_{\mathrm{X}}\right)$ and lower $\left(Q_{\mathrm{x} 0}\right)$ horizontal convective flows, the vertical convective $\left(Q_{\mathrm{Z}}\right)$ and diffusive $\left(M_{\mathrm{Z}}\right)$ flows and 'boundary movement' $\left(Q_{\mathrm{E}}=d V / d t\right)$ in the Ría de Arousa from May to October 
1989 with a 2-D non-stationary salt-heat weighted box model (Fig. 2). $Q_{\mathrm{E}}$ is due to time-changes in the layer volumes (V), associated to the net vertical displacement of the boundary between the upper and lower. The inputs to the model are: 1) the profiles of salinity and temperature at the 10 sampling sites; 2) $Q_{\mathrm{R}}+P-E$ and $F_{\mathrm{Q}}$; and 3) the geometry of the Ría (surface and cross areas, volumes), obtained from accurate charts published by the Spanish 'Instituto Geográfico de la Marina’.

Knowledge of water flows and average concentrations of the different species of every study element in the upper and lower volumes and cross areas considered (Table 1), allow us to obtain species fluxes and net budgets. The flux of any chemical species $\left(F_{\mathrm{Qi}}\right)$ transported by a convective water flow $\left(Q_{\mathrm{i}}\right)$ is the product of flow times concentration $\left(C_{\mathrm{i}}\right): F_{\mathrm{Qi}}=Q_{\mathrm{i}} \cdot C_{\mathrm{i}}$. The river flux is $F_{\mathrm{R}}=Q_{\mathrm{R}} \cdot C_{\mathrm{R}}$, with $C_{\mathrm{R}}$ the concentration in the river flow. The vertical diffusive flux is $D=M_{\mathrm{Z}} \cdot\left(C_{\mathrm{L}}-C_{\mathrm{U}}\right)$, being $C_{\mathrm{L}}$ and $C_{\mathrm{U}}$ the concentrations in the upper and lower layer, respectively. The 'boundary movement' flux is $F_{\mathrm{E}}=C \cdot d V / d t$. Finally, $F_{\mathrm{ATM}}$ is the $\mathrm{CO}_{2}$ or $\mathrm{O}_{2}$ air-sea exchange flux, taken from Rosón et al. (1999) and calculated from eq (2) respectively. Concentrations are in $\mathrm{mol} \mathrm{m}^{-3}$, water flows in $\mathrm{m}^{3} \mathrm{~s}^{-1}$ and species fluxes in $\mathrm{mol} \mathrm{s} \mathrm{s}^{-1}$.

The budget of inputs and outputs (i-o, in $\left.\mathrm{mol} \mathrm{s}^{-1}\right)$ of any species in the Ría results from accumulation, $\partial(C \cdot V) / \partial t$, and biogeochemical processes, $\delta C$ (positive, production; negative, consumption). Therefore:

$$
\begin{aligned}
& i-o=Q_{\mathrm{R}} \cdot C_{\mathrm{R}}+Q_{\mathrm{XO} 7} \cdot C_{\mathrm{O} 7}+Q_{\mathrm{X} 1} \cdot C_{1}+Q_{\mathrm{X} 8} \cdot C_{8}-Q_{\mathrm{X} 7} \cdot C_{7}-Q_{\mathrm{XO} 1} \cdot C_{\mathrm{O} 1}-Q_{\mathrm{XO} 8} \cdot C_{\mathrm{O} 8}-F_{\mathrm{ATM}} \\
& \delta C=\frac{\partial(C \cdot V)}{\partial t}-(i-o)
\end{aligned}
$$

The average $\delta C$ between surveys $\mathrm{j}-1$ and $\mathrm{j}\left(\Delta C\right.$, in $\left.\mathrm{mol} \mathrm{s}^{-1}\right)$ can be obtained by integrating Eq. (4): 


$$
\Delta C=\frac{\int_{t_{j-1}}^{t_{j}} \delta C d t}{t_{j}-t_{j-1}}=V \cdot \frac{C_{t}-C_{t-1}}{t_{t}-t_{t-1}}-\frac{\int_{t_{j-1}}^{t_{j}}(i-o) \cdot d t}{t_{t}-t_{t-1}}
$$

Average $i-o$ between surveys $\mathrm{j}-1$ and $\mathrm{j}$ was calculated assuming linear changes from $t_{\mathrm{j}-1}$ to $t_{\mathrm{j}}$ of 1) salinity, temperature, $Q_{\mathrm{R}}+P-E, F_{\mathrm{Q}}$ and $V$, for calculating water flows and 2) $C, C_{\mathrm{i}}$ and $C_{\mathrm{R}}$ for calculating fluxes. Finally, values of $\Delta C$ in mol s${ }^{-1}$ are converted to $\mathrm{mmol} \mathrm{m}^{-2} \mathrm{~d}^{-1}$ multiplying by the factor 0.474 , which considers the surface area of the Ría de Arousa (182.4 $\left.\mathrm{Km}^{2}\right)$. The budget of any species in the upper layer would require to consider the river flux $\left(F_{\mathrm{R}}\right)$ the inward and outward horizontal convective fluxes $\left(F_{\mathrm{Qx} 1}, F_{\mathrm{Qx} 8}, F_{\mathrm{Qx} 7}\right)$, the three vertical fluxes ( $F_{\mathrm{Qz}}, F_{\mathrm{E}}$ and $D$ ) and $F_{\mathrm{ATM}}$. The budget for the lower layer can be obtained by subtracting the budget of the upper layer form the budget of the box.

Fluxes and net budgets of nitrogen and carbon species were taken from Álvarez-Salgado et al. (1996a) and Rosón et al. (1999) respectively, who described the method above in more detail. Oxygen, phosphorus, silicon and chlorophyll fluxes and budgets were calculated for the present work.

\subsection{Error in the calculation of species fluxes and budgets}

Rosón et al. (1997) reported average \pm std errors of $0.002 \pm 0.029$ pss and $0.012 \pm 0.387^{\circ} \mathrm{C}$ produced by the 2-D non-stationary box model on the salinity and temperature budgets respectively. These errors represent a $<1 \%$ error on water fluxes when compared with the average vertical gradients of salinity $(0.234 \mathrm{pss})$ and temperature $\left(1.7^{\circ} \mathrm{C}\right)$. However the standard deviation of errors represents $10-20 \%$ of the average gradient, producing the corresponding errors in the water flows. The time course of the thermohaline and chemical fields are strongly coupled (Table 1) in response to the succession of upwelling/downwelling events (AlvarezSalgado et al. 1993, Rosón et al. 1995). Therefore, it must be expected that the average error in species budgets are similar to the average errors in salinity and temperature. 
It is possible also to derive the error in water and species fluxes and budgets associated to the precision on the determination of the variables contributing to the calculation of fluxes and budgets. Since the density gradients in the Ría de Arousa during the study period are mainly (85\%) controlled by temperature, the error of the 2-D box model during the estimation of $Q_{\mathrm{X}}$ $\left(\varepsilon_{q}\right)$ can be determined as:

$\varepsilon_{q}=\frac{\varepsilon_{R} \cdot\left(\bar{T}_{I}-T_{R}\right)+\varepsilon_{D}+\varepsilon_{H}+2 \cdot \varepsilon_{T} \cdot\left(\left|Q_{X}\right|+Q_{R}\right)}{\bar{T}_{I}-\bar{T}_{O}}$

where $\varepsilon_{R}$ is the error in the river flows $\left( \pm 0.5 \mathrm{~m}^{3} \mathrm{~s}^{-1}\right), T_{R}$ is the average river temperature, $\varepsilon_{D}$ is the error in the estimation of the heat exchange across the sea surface $\left( \pm 3 \cdot 10^{9} \mathrm{cal} \mathrm{s}^{-1}\right), \varepsilon_{D}$ is the error in the estimation of the heat content change of the Ría de Arousa $\left(V \cdot 2 \varepsilon_{T} /\left(t_{j}-t_{j-1}\right)=\left(4.2 \cdot 10^{9} \cdot 0.02 / 3.5 \cdot 86400\right)= \pm 278{ }^{\circ} \mathrm{C} \mathrm{m}^{3} \mathrm{~s}^{-1}\right)$ and $\varepsilon_{T}$ is the error of temperature measurements $\left(0.01^{\circ} \mathrm{C}\right)$. The average $Q_{\mathrm{x}}, Q_{\mathrm{R}}$ and the vertical gradient of temperature are $3300 \mathrm{~m}^{3} \cdot \mathrm{s}^{-1}, 27 \mathrm{~m}^{3} \cdot \mathrm{s}^{-1}$ and $1.7^{\circ} \mathrm{C}$, respectively. So, the average $\varepsilon_{q}$ is $\pm 210 \mathrm{~m}^{3} \cdot \mathrm{s}^{-1}$, equivalent to $6 \%$ of $Q_{\mathrm{X}}$.

Considering the conservation of volume $\left(Q_{\mathrm{X}}=Q_{\mathrm{XO}}+R\right)$ and the very low contribution of continental runoff to the error calculation of species budgets, equation (3) can be simplified as:

$i-o=Q_{\mathrm{XO} 7} \cdot\left(C_{\mathrm{O} 7}-C_{7}\right)-Q_{\mathrm{XO} 1} \cdot\left(C_{\mathrm{O} 1}-C_{1}\right)-Q_{\mathrm{XO} 8} \cdot\left(C_{\mathrm{O} 8}-C_{8}\right)-F_{\mathrm{ATM}}$

After replacement of eq. (3) by eq. (7) in eq. (4) and (5) the resulting error of any species budget $\left(\varepsilon_{\Delta C}\right)$ is:

$$
\varepsilon_{\Delta C}=V \cdot \frac{2 \varepsilon_{C}}{\left(t_{j}-t_{j-1}\right)}+2 \varepsilon_{C} \sum_{i=1,7,8} Q_{i}+\overline{(C o-C)} \cdot \sum_{i=1,7,8} \varepsilon_{q}+\varepsilon_{F a t m}
$$

where $\varepsilon_{C}$ is the analytical error of the species (Table 2), $\varepsilon_{\text {Fatm }}$ is the error of flux exchange for $\mathrm{CO}_{2}\left( \pm 0.2 \mathrm{~mol} \mathrm{~s}^{-1}\right)$ and $\mathrm{O}_{2}\left( \pm 1 \mathrm{~mol} \mathrm{~s}^{-1}\right)$, and $\overline{\mathrm{Co}-\mathrm{C}}$ is the average vertical gradient in the volume bounded by stns $1,8,7$ and 10 (Table 1). The average estimated error for the 
upwelling season and the autumn downwelling are shown in Table 2. These errors for $\mathrm{O}_{2}, \mathrm{~N}_{T}$, phosphate and silicate are $20-30 \%$ of $\Delta \mathrm{C}$ for both the upwelling and downwelling periods. The estimated average error for $\Delta C_{\mathrm{T}}$ is about $60-70 \%$, due to the high $\varepsilon_{\mathrm{C}} /\left(C_{\mathrm{O}}-C\right)$ ratio for $\mathrm{C}_{\mathrm{T}}$ compared with the other species. However, these large error estimations are in contradiction with the high correlations of $\Delta C_{\mathrm{T}}$ with $\Delta \mathrm{O}_{2}$ and $\Delta N_{\mathrm{T}}$ (Table 3) suggesting that the proper error of $\Delta \mathrm{C}$ for any species have to be much lower than the errors estimated in Table 2. A similar reasoning can be applied to the particulate organic matter budgets. Following Matsukawa and Suzuki (1985) 'this is probably because the terms and properties involved in the calculations are so many that the averaging effect acting on the independent errors become large enough to decrease the real errors considerably'. So, the real contribution of the analytical error is probably much lower than expected from eq. (8).

\section{Result}

\subsection{Coupling between $\mathrm{O}_{2}, C, N, P$ and Si species net production rates}

The net consumption of total inorganic carbon $\left(\Delta C_{\mathrm{T}}\right)$, total inorganic nitrogen $\left(\Delta N_{\mathrm{T}}\right)$ and phosphate $(\Delta P)$ is compared with the net production of oxygen $\left(\Delta \mathrm{O}_{2}\right)$, obtained solving eq. (5) for the chemical species considered (Table 3). $\Delta C_{\mathrm{T}}$ (Rosón et al., 1999) and $\Delta \mathrm{O}_{2}$ have to be corrected previously. The contribution of calcium carbonate fixation $\left(\triangle \mathrm{CaCO}_{3}\right)$, not related to $\mathrm{O}_{2}$ production, have to be subtracted from $\Delta C_{\mathrm{T}}$. For deep ocean waters $\Delta \mathrm{CaCO}_{3}=$ $-1 / 2 \cdot\left(\Delta \mathrm{TA}+\Delta \mathrm{NO}_{3}{ }^{-}\right)$(Broecker and Peng, 1982; Takahashi et al., 1985). However, for coastal and estuarine waters the contribution of nitrite and ammonium have to be considered as well (Fraga et al., 1992):

$$
\Delta C_{\mathrm{TCOR}}=\Delta C_{\mathrm{T}}+\Delta \mathrm{CaCO}_{3}=\Delta C_{\mathrm{T}}-1 / 2 \cdot\left(\Delta \mathrm{TA}+\Delta N \mathrm{NO}_{3}{ }^{-}+0.45 \cdot \Delta N \mathrm{NO}_{2}^{-}-\Delta N H_{4}{ }^{+}\right)
$$

The amount of $\mathrm{O}_{2}$ produced during the synthesis of phytogenic organic matter depend on the inorganic nitrogen source (nitrate, nitrite or ammonium). The synthesis from nitrate produce 0.5 and 2 moles of $\mathrm{O}_{2}$ per mol of $\mathrm{N}$ consumed more than from nitrite and ammonium, 
respectively. Therefore, in order to compare $\Delta N_{\mathrm{T}}$ with $\Delta \mathrm{O}_{2}$, it is necessary to refer $\Delta \mathrm{O}_{2}$ to an unique nitrogen source (Smith and Hollibaugh, 1997). We have used nitrate as reference to compare with the stoichiometric ratio $R_{\mathrm{N}}\left(=-\Delta \mathrm{O}_{2} / \Delta N \mathrm{O}_{3}^{-}\right)$for deep ocean waters (Minster and Buholahdid, 1987). Following Fraga et al. (1992):

$\Delta O_{2 \mathrm{COR}}=\Delta \mathrm{O}_{2}-0.5 \cdot \Delta N \mathrm{O}_{2}^{-}-2 \cdot \Delta N H_{4}^{+}$

Since $\Delta P$ and $\Delta C_{\mathrm{TCOR}}$ are associated to the net consumption of the three nitrogen forms, it is necessary to use $\Delta O_{2 \mathrm{COR}}$ to compare with the corresponding stoichiometric ratios $R_{\mathrm{P}}$ $\left(=-\Delta O_{2} / \Delta P\right)$ and $R_{\mathrm{C}}\left(=-\Delta O_{2} / \Delta C_{\mathrm{T}}\right)$. The recently revised $-\mathrm{O}_{2} / \mathrm{C} / \mathrm{N} / \mathrm{P}$ Redfield ratios are 149/106/16/1 (Anderson, 1995; Fraga et al., 1998), yielding a reference values of $R_{\mathrm{C}}, R_{\mathrm{N}}$ and $R_{\mathrm{P}}$ of $1.41,9.31$ and 149 respectively.

The direct correlation of $\Delta C_{\mathrm{TCOR}}, \Delta N_{\mathrm{T}}$, and $\Delta P$ with $\Delta O_{2 \mathrm{COR}}$ is $r^{2}=0.74-0.86$ (model II; Sockal and Rolhf, 1995), indicating a strong coupling between the consumption of nutrient salts and the production of dissolved oxygen at the short time scale (3-4 days). The calculated slopes (Table 3) are on a par with the stoichiometric ratios $R_{\mathrm{C}}, R_{\mathrm{N}}$ and $R_{\mathrm{P}}$. Whereas our $R_{\mathrm{N}}$ value of $9.7 \pm 0.8$ agrees with the values usually obtained during the mineralization of organic matter in oxic conditions, our $R_{\mathrm{P}}$ of $142 \pm 14$ is in the low end of the wide range reported in the literature (Redfield et al., 1963; Takahashi et al., 1985; Minster and Boulahdid, 1987; Pérez et al., 1993; Anderson and Sarmiento, 1994; Anderson, 1995; Castro et al., 1998). On the other hand, our $R_{\mathrm{C}}$ of $1.05 \pm 0.06$ is rather low compared with the revised Redfield value. Although the y-intercept of the regression between $\Delta O_{2 \mathrm{COR}}$ and $\Delta N_{\mathrm{T}}$ is not significantly different from zero, the corresponding regressions with $\Delta C_{\mathrm{TCOR}}$, and $\Delta P$ indicate a significant $\mathrm{CO}_{2}$ and $\mathrm{HPO}_{4}{ }^{2-}$ production (i.e. mineralization) of 26 and $0.27 \mathrm{mmol} \mathrm{m}^{-2} \mathrm{~d}^{-1}$ at $\Delta O_{2 \mathrm{COR}}=0$. These figures represent $\sim 30 \%$ and $20 \%$ of the total variability in $\Delta C_{\mathrm{TCOR}}$ and $\Delta P$, respectively.

The correlations between $\Delta C_{\mathrm{TCOR}}, \Delta N_{\mathrm{T}}$, and $\Delta P$ are very high as well $\left(r^{2}=0.75-0.85\right)$ with a N/P ratio of $15 \pm 1$ and a C/N ratio of $8.4 \pm 0.8$ — well above the Redfield value of 6.6 , in agreement with the low $R_{\mathrm{C}}$ obtained. On the other hand, the correlation between $\Delta S i$ and $\Delta N_{\mathrm{T}}$, is 
much lower $\left(r^{2}=0.61\right)$, as silicate is only consumed by diatoms. The slope of the correlation gives a $\mathrm{N} / \mathrm{Si}$ ratio of $1.4 \pm 0.2$, higher than the world average $\mathrm{N} / \mathrm{Si} 1 / 1$ ratio of marine diatoms (Nelson et al., 1995). In addition, the y-intercept denote net mineralization of $3.6 \mathrm{mmol} \mathrm{m}^{-2} \mathrm{~d}^{-1}$ of silicate at $\Delta N_{\mathrm{T}}=0$, which represents about $30 \%$ of the total variability of $\Delta S i$.

The net production of suspended organic carbon $(\triangle P O C)$, nitrogen $(\triangle P O N)$, phosphorous $(\triangle P O P)$ and chlorophyll ( $\triangle$ Chla) can be obtained by solving eq. (5) for all these organic substances. The time evolution of the different organic components are coupled at the short-time scale $\left(r^{2}=0.74-0.96\right)$. The $y$-intercept of the corresponding regression equations is not significantly different from zero (Table 3). The slope of the $\triangle P O C-\triangle P O N$ regression (6.3 \pm 0.2 ) agrees very well with the Redfield $\mathrm{C} / \mathrm{N}$ ratio for healthy phytoplankton, and it is $\sim 25 \%$ lower than the $\mathrm{C} / \mathrm{N}$ ratio of nutrients consumption. On the contrary, the corresponding $\mathrm{C} / \mathrm{P}$ ratio is $69 \pm 6$, about half of the $\Delta C_{T \mathrm{COR}} / \Delta P$ ratio of $135\left(=\mathrm{R}_{\mathrm{P}} / \mathrm{R}_{\mathrm{C}}\right)$. The slope of the $\Delta P O C-\Delta C h l a$

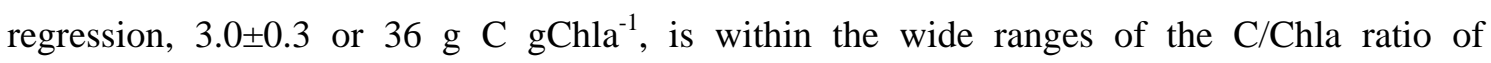
phytogenic organic matter reported in the literature (Antia et al., 1963; Ríos, 1992). A ratio of 40 is commonly used to convert chlorophyll to carbon in cultures of healthy phytoplankton (Eppley et al., 1977). The C/Chla ratio for diatoms species in the adjacent Ría de Vigo ranges from 35 to 50 (Ríos et al., 1998) and a value of 41 for diatoms was recorded by Eppley et al. (1977) in the upwelling of California.

\subsection{Contrasting $-\mathrm{O}_{2} / \mathrm{C} / \mathrm{N} / \mathrm{P} / \mathrm{Si}$ ratios under average upwelling and downwelling conditions.}

The upwelling season. The characteristic succession of wind stress-relaxation events during the upwelling season is observed from June 8 to October 12 (Fig. 5a). The average $I_{\mathrm{W}}$ for this period is $0.5 \mathrm{~m}^{2} \mathrm{~s}^{-1}$. As much as $5069 \mathrm{~m}^{3} \mathrm{~s}^{-1}$ of ENACW-rich shelf bottom water enters the ría during the upwelling season (Fig 6a). Half of them go into the upper layer in the vertical convective flow $\left(2540 \mathrm{~m}^{3} \mathrm{~s}^{-1}\right.$ or $\left.1.2 \mathrm{~m} \mathrm{~d}^{-1}\right)$ and the other half penetrate in the estuarine part of the ría, off the study volume. Considering the volume and the residual flows, the average residence time of water within the Ría is $\sim 6.3$ days. Vertical mixing represented $5205 \mathrm{~m}^{3} \mathrm{~s}^{-1}$ or $2.4 \mathrm{~m} \mathrm{~d}^{-1}$, twice the vertical convective flow. 
The average $\Delta C_{\mathrm{TCOR}}, \Delta N_{\mathrm{T}}, \Delta P$ and $\Delta S i$ for the upwelling season (Table 4) represent 1.4, 54, 39 and $25 \%$ of the total input of $\mathrm{C}_{\mathrm{T}}, \mathrm{N}_{\mathrm{T}}$, phosphate and silicate into the ría (Fig. 6b). Therefore, $\mathrm{N}_{\mathrm{T}}$ is the most efficiently trapped nutrient salt during the upwelling season into the Ría. Although the N/P and N/Si molar ratios in the subsurface ingoing flow are 15.5 and 1.46 respectively, they reduce to 10.7 and 0.84 in the surface outgoing flow. This reduction is due to the very high average $\Delta N_{\mathrm{T}}: \Delta P$ and $\Delta N_{\mathrm{T}}: \Delta S i$ (Table 4) compared with the expected values from the average composition of marine phytoplankton, 16 (Anderson, 1995) and 1 (Nelson et al., 1995) respectively. $\mathrm{O}_{2}$ delivered to the atmosphere was $22 \%$ of $\Delta \mathrm{O}_{2 \mathrm{COR}}$ and the remaining $78 \%$ enriches the surface outgoing flow. On the contrary, the $\mathrm{CO}_{2}$ flux to the atmosphere represents only $0.03 \%$ of the $\mathrm{C}_{\mathrm{T}}$ flux into the Ría and $2 \%$ of $\Delta C_{\mathrm{TCOR}}$. The average $R_{\mathrm{C}}$ and $R_{\mathrm{N}}$ are very close to the expected values for autotrophic synthesis of organic matter.

Net mineralization of $35 \%$ of $C_{\mathrm{T}}, 17 \%$ of $N_{\mathrm{T}}, 35 \%$ of phosphate and $57 \%$ of silicate consumed in the upper level occurs in the lower layer during the upwelling season, using $30 \%$ of oxygen produce in the upper layer. Nutrient consumption in the upper layer and mineralization in the lower layer contribute to increase the vertical gradient of nutrients, enhancing the vertical mixing fluxes and modifying the corresponding nutrient ratios. The N/P and N/Si ratios in the upward convective flow are 12.4 and 0.96 respectively. They are lower than in the bottom ingoing flow because of the mineralization ratios in the lower layer. On the contrary, these ratios in the mixing flow are 22 and 2.6 respectively, very close to the average net consumption ratios observed. Finally, the average N/P and N/Si ratios in the three upward flows $\left(Q_{\mathrm{Z}}, M_{\mathrm{Z}}\right.$ and $\left.Q_{\mathrm{E}}\right)$, i.e. the nutrient ratios feeding the phytoplankton population in the upper layer, are 15.8 and 1.4 respectively. Consequently, the large modification of the N/P and N/Si ratios within the ría occurs mainly in the upper layer.

Average $\triangle P O C, \triangle P O N$ and $\triangle P O P$ during the upwelling season (Table 4) represent an increase of 130, 90 and $100 \%$ compared with the corresponding organic loads in the bottom ingoing flow (Fig. 6c). Only 17\% of POC and PON and 6.5\% of POP produced in the upper layer is mineralised in the lower layer. $\triangle P O C$ and $\triangle P O N$ are $\sim 1 / 3$ of $\Delta C_{\mathrm{TCOR}}$ and $\Delta N_{\mathrm{T}}$ 
respectively, whereas $\triangle P O P$ is as much as $\sim 2 / 3$ of $\triangle P$. The average $\triangle P O C: \triangle P O N$ is $\sim 15 \%$ lower than the $\mathrm{C} / \mathrm{N}$ ratio of POM coming from the shelf, in such a way that the $\mathrm{C} / \mathrm{N}$ ratio in the surface outgoing flow is $\sim 8 \%$ lower than in the bottom ingoing flow. Therefore, during the upwelling season the ría is delivering to shelf surface water a large load of nitrogen-rich POM. On the contrary the organic N/P ratio in the bottom ingoing and the surface outgoing flows are quite similar at $\sim 11$. The average $\Delta$ Chla represents $\sim 280 \%$ of the Chla load in the bottom ingoing flow from the shelf.

The autumn downwelling. Intense southerly winds provoked strong downwelling form 13 to 30 of October (Fig $5 \mathrm{a}$ ). The average $I_{\mathrm{W}}$ for this period was $-0.5 \mathrm{~m}^{2} \mathrm{~s}^{-1}$, provoking a pronounced reversal in the circulation with the entry of shelf surface water into the ría (Fig. 7a). The values of $Q_{\mathrm{X} 7}, Q_{\mathrm{z}}$ and $Q_{\mathrm{xO}}$ are strongly negative, leading to a residence time of only 3.7 days in the volume studied. The circulation is still positive in the estuarine part of the ría. The vertical downward $\left(-6 \mathrm{~m} \mathrm{~d}^{-1}\right)$ and mixing $\left(3.4 \mathrm{~m} \mathrm{~d}^{-1}\right)$ flows are extremely high.

The average $\Delta C_{\mathrm{TCOR}}, \Delta N_{\mathrm{T}}, \Delta P, \Delta S i$ for the autumn downwelling are strongly positive, i.e. the hydrodynamic conditions favoured net nutrient mineralization in the volume considered (Table 4). About $21 \%$ of the $\mathrm{O}_{2}$ consumed during this period came from the atmosphere. Conversely, $\sim 8 \%$ of $\Delta C_{\mathrm{TCOR}}$ is lost to the atmosphere because of the very high surface $\mathrm{pCO}_{2}$ levels and the local strong winds (6 $\mathrm{m} \mathrm{s}^{-1}$; Rosón et al, 1999). Although the average $R_{\mathrm{N}}$ is close the revised Redfield value, $R_{\mathrm{C}}, \Delta N_{\mathrm{T}}: \Delta P$ and $\Delta N_{\mathrm{T}}: \Delta S i$ are low. Most of the mineralization occurs in the upper box: 89, 103, 98 and $71 \%$ of $\mathrm{C}_{\mathrm{T}}, \mathrm{N}_{\mathrm{T}}$, phosphate and silicate. As a consequence of the nutrient mineralization ratios, the high N/P ratio in the surface ingoing flow (13.6) decreased to 12.6 in the to the bottom outgoing flow. Conversely, the very low N/Si ratio of 0.69 in the surface ingoing flow increases to 0.93 in the bottom outgoing flow.

The $\triangle P O C: \triangle P O N$ and $\triangle P O N: \triangle P O P$ during the mineralization of the organic matter in the volume studied (Table 4) are close to the Redfield values. Chla entering the ría in the surface incoming flow is mineralised at an average rate of $8.6 \mathrm{~g} \mathrm{~s}^{-1}$, being the $\triangle P O C: \triangle C h l a$ mass ratio as high as 125 . 


\subsection{Parametrising the NEP of the Ría de Arousa}

Since the time courses of $\Delta C_{\mathrm{TCOR}}, \Delta N_{\mathrm{T}}$ and $\Delta P$ are parallel to $\Delta O_{2 \mathrm{COR}}$, we have converted $-\Delta C_{\mathrm{TCOR}},-\Delta N_{\mathrm{T}}$ and $-\Delta P$ into $\mathrm{mmol} \mathrm{m}^{-2} \mathrm{~d}^{-1}$ of $\mathrm{O}_{2}$ (Fig. 3a), using the linear regressions in Table

3. The average net oxygen production rates obtained from the four series of independent values $\left(C_{\mathrm{TCOR}}, N_{\mathrm{T}}, P\right.$ and $\left.\mathrm{O}_{2 \mathrm{COR}}\right)$ can be considered the net ecosystem production of the Ría $(<N E P>$ ), i.e. the primary production minus the respiration of autothrophus and all heterothropus in the volume studied (Smith and Hollibaugh, 1997). In the same way, $\triangle P O N, \triangle P O P$ and $\triangle C h l a$ have been converted into mmol m${ }^{-2} \mathrm{~d}^{-1}$ of POC (Fig. 3b) using the corresponding regressions in table 3 to obtain an average POC production rate $(<P O C>)$. Although the time evolutions are quite parallel, the direct correlation between $<N E P>$ and $<P O C>$ is not so good, $r^{2}=0.58$ (Fig. 4). If $<N E P>$ is converted into carbon units, the slope of the correlation with $<P O C>(0.33)$ indicates that only $1 / 3$ of the NEP is transformed into exportable POC along the study period.

The seven major $<N E P>$ maxima in Fig. 3b (ranging from 200 to $400 \mathrm{mmol} \mathrm{m}^{-2} \mathrm{~d}^{-1}$ ) occur one sampling (3-4 days) after the periodic entries of nutrient-rich ENACW. The time evolution of the Ekman transport $I_{\mathrm{W}}$ (Fig. 5a) — which forces ENACW into the ría - is a succession of peaks (upwelling) and toughs (relaxation) with a periodicity of $14 \pm 4 \mathrm{~d}$ (Álvarez-Salgado et al., 1993). Upwelling relaxations are accompanied by $<N E P>$ minima (ranging from 0 to $-75 \mathrm{mmol} \mathrm{m} \mathrm{d}^{-1}$ ) in between two maxima. Large negative values of $I_{\mathrm{W}}$ at the end of the study period indicate strong downwelling conditions coinciding with the pronounced minimum of $\langle\mathrm{NEP}\rangle=-116 \mathrm{mmol} \cdot \mathrm{m}^{-2} \cdot \mathrm{d}^{-1}$. The stability of the water column (average depth-integrated Brunt-Väisälä frequency, BV) also contribute to module the NEP of the ría: it reduce the vertical diffusive flux of nutrients to the photic layer during upwelling relaxations and increases the efficiency of nutrient uptake by primary producers during upwelling events. As a general trend, $B V$ increases during relaxations and decreases during upwelling or downwelling conditions (Fig. 5c). The observed decreasing trend along the study period $\left(r^{2}=0.64, \mathrm{n}=45, p<0.0001\right)$ is probably associated to the decreasing heat exchange flux $F_{\mathrm{Q}}$ (Fig. 5b). Such a general decreasing trend of $-0.7 \mathrm{mmol} \mathrm{m}^{-2} \mathrm{~d}^{-1}$ is observed in $\langle N E P>$ as 
well $\left(r^{2}=0.27 n=46, p<0.08\right)$. Therefore, we have tried to quantify the influence of upwelling, stability and heat flux on the NEP looking for the linear combination of $I_{\mathrm{W}}, B V$ and $F_{\mathrm{Q}}$ which explains better the time evolution of $\left\langle N E P>\right.$. The best fit $\left(r^{2}=0.70\right)$ was obtained with the equation:

$$
<N E P>=70( \pm 16) \cdot I \mathrm{w}_{12}-35( \pm 14) \cdot I \mathrm{w}_{0}+0.38( \pm 0.06) \cdot\left(F \mathrm{Q}_{0}+F \mathrm{Q}_{1}\right)-(198 \pm 37) \cdot B V
$$

where $B V, I \mathrm{w}_{0}$ and $F_{\mathrm{Q}_{0}}$ are the average Brünt-Väisälä frequency $\left(\mathrm{min}^{-1}\right)$, Ekman transport $\left(\mathrm{m}^{2}\right.$ $\mathrm{s}^{-1}$ ) and heat exchange flux $\left(\mathrm{cal} \mathrm{cm}^{-2} \mathrm{~d}^{-1}\right)$ from $\mathrm{t}_{\mathrm{j}-1}$ to $\mathrm{t}_{\mathrm{j}} ; F_{\mathrm{Q}_{1}}$ is the average $F_{\mathrm{Q}}$ from $\mathrm{t}_{\mathrm{j}-2}$ to $\mathrm{t}_{\mathrm{j}-1}$; and $I \mathrm{w}_{12}$ is the average $I_{\mathrm{W}}$ from $\mathrm{t}_{\mathrm{j}-3}$ to $\mathrm{t}_{\mathrm{j}-1}$. The river input does not contribute significantly to explain the variance of $\langle N E P>$. Fig. $5 d$ compares the $<N E P>$ rates in Fig. 3a with those calculated with eq. 11. It shows the good agreement between the NEP calculated from the time variability of thermohaline and biogeochemical properties, and the NEP parametrised using the external physical forces of the ecosystem (upwelling and irradiance) and the stability of the water column.

\section{Discussion and conclusions}

\subsection{The dramatic effect of hydrography on the $\mathrm{O}_{2} / C / N / P / S i$ stoichiometry of $N E P$}

Pronounced differences have been observed between the N/P ratios of net nutrient uptake and organic matter production during the upwelling season. The average $\Delta N_{\mathrm{T}} / \Delta P$ is $\sim 30 \%$ higher than and the $\triangle P O N / \triangle P O P$ is $\sim 30 \%$ lower than the expected value of 16 during the synthesis of the organic tissues of marine phytoplankton (Laws, 1991; Anderson, 1995; Fraga et al., 1998). Conversely, $R_{\mathrm{N}}$ keeps the expected ratio during phytoplankton production. The well-known longer recycling times of nitrogen compared with phosphorus (Harrison, 1980; Garber, 1984) could explain the high average N/P ratio during the net uptake of $\mathrm{N}_{\mathrm{T}}$ and phosphate in the $\sim 6$ days average residence time within the study volume. The same behaviour has been recorded by Nogueira et al. (1997) in the adjacent Ría de Vigo. In this sense, Treguer and Le Corre (1979), who obtained a N/P ratio of 18.5 during nutrient uptake, observed that phosphorous regeneration is $\sim 30 \%$ faster than nitrogen regeneration mediated by zooplankton 
or animal excretion in the upwelling off Morocco. Conversely, the low N/P ratio of the suspended organic matter produced, concomitant with a Redfield $\mathrm{C} / \mathrm{N}$ ratio, indicates a substantial contribution of detritus colonised by bacteria, which is probably related with the intensive hanging mussel culture. Low N/P ratios in suspended organic matter were observed during an annual cycle in the Ría de Vigo (average, 12.8). Detritus represented 24\% of the suspended material (Ríos et al., 1998). Accordingly, Copin-Montégut and Copin-Montégut (1983) observed very low C/P ratios in suspended organic matter of the NW Africa upwelling system.

The extremely low average $\Delta N_{\mathrm{T}} / \Delta P=7.4$ during downwelling conditions contrasts with the N/P ratio of the mineralised suspended organic matter. The same behaviour was observed by Howarth (1988) in Narragansett Bay, where suspended organic matter enters the sediments with a N/P ratios of 16 , but nutrient are released back to the water column with a ratio of 6 . In addition, the N/P ratio of mineralised nutrients in the NW and SW Africa upwelling systems ranges from 8 to 12 (Jones, 1971; Rowe et al., 1977; Treguer and Le Corre, 1979). Since the $R_{\mathrm{N}}=10.0$ observed in the Ría de Arousa during the downwelling event is within the expected ranges during the oxidation of phytogenic organic matter in oxic conditions, denitrification processes within the sediments seems not to be the reason behind the low $\Delta N_{\mathrm{T}} / \Delta P$. Therefore, the most likely explanations have to be the faster recycling rates of phosphorus within the sediments, or the alternative hypothesis of phosphate release from interstitial water by processes independent of organic matter oxidation (Suess, 1981). The short residence time of upwelled ENACW in the Ría precludes denitrification, which occurs in estuarine system with long residence time as Tomales Bay in the upwelling region of California (Smith and Hollibaugh, 1997).

The average N/Si net uptake ratio during the upwelling season (3.2) was much higher than the expected value from the average composition of marine diatoms ( 1; Brezinski, 1985; Nelson et al., 1995). Pazos et al. (1995) have demonstrated that the periodic wind stress/relaxation sequence selected the microplankton species inside the Ría de Arousa, which 
results in the annual succession from small pioneer diatoms to red-tide species occurring several times during the upwelling season 1989. Therefore, non-siliceous species have a relevant contribution to the phytoplankton population in the ría, which increases the average N/Si ratio. In the upwelling of Monterrey Bay (California), direct measurements of nitrate and silicate uptake yields $\mathrm{N} / \mathrm{Si}$ ratios ranging from 0.8 under upwelling conditions to 10 under nutrient depletion (White and Dugdale, 1997). In the NW Africa upwelling system, Treguer and Le Corre (1979) obtained a very low ratio of 0.33 using a simple water-masses mixing linear model.

The average N/Si net mineralization ratio during the autumn downwelling decreases to 1.0, pointing to the dissolution of the diatom frustules deposited into the Ría de Arousa. Following Chapman and Shannon (1985), the main reason for the silicate increase that they found in shelf bottom waters off Namibia is the dissolution of silica, which has been deposited either as zooplankton faeces or as undigested diatom frustules. In the case of the Rías Baixas, the contribution of the extensive bottom biodeposits generated by mussel cultured on hanging ropes have to be considered as well (Tenore et al., 1982). In this sense, large opal deposits have been observed in shelf sediments of the NW Iberian Peninsula (Prego and Bao, 1997). Álvarez-Salgado et al. (1997) found N/Si mineralization ratios of 1.2-1.5 in shelf waters off the rías and values ranging from 0.7 to 1.2 have been observed in the NW Africa upwelling system (Treguer and Le Corre, 1979; Friedrerich and Codispoti 1979).

The average $\mathrm{C} / \mathrm{N}$ net uptake ratio by the community of organisms into the Ría de Arousa during the upwelling season (6.9) is slightly higher than the average $\mathrm{C} / \mathrm{N}$ net production ratio of suspended organic matter (6.3). Since suspended organic matter represents only $\sim 1 / 3$ of the total $\Delta C_{\mathrm{TCOR}}$ and $\Delta N_{\mathrm{T}}$, the remaining organic matter produced (dissolved and deposited) must have an average C/N ratio of 7.2. Álvarez-Salgado et al. (1996a) and Rosón et al. (1999) reported that $\sim 17 \%$ of the net uptake of $\mathrm{C}_{\mathrm{T}}$ and $\mathrm{N}_{\mathrm{T}}$ sedimented to the bottom and the remaining $50 \%$ was in the form of dissolved organic matter because of the intensive culture of mussels on hanging ropes. On the contrary, the average $\mathrm{C} / \mathrm{N}$ ratio of the nutrients mineralised during 
the autumn downwelling event is as high as 9.9 , whereas the $\mathrm{C} / \mathrm{N}$ ratio of the suspended organic matter mineralised keeps at 6.7. As for the previous cases, diffusion to the water column of $\mathrm{CO}_{2}$ produced during the mineralization of $\mathrm{C}$-rich organic matter deposited in the pelagic sediments of the ría have to be the reason behind the observed inorganic $\mathrm{C} / \mathrm{N}$ ratio. Álvarez-Salgado et al. (1996a) and Rosón et al. (1999) suggested the pelagic sediments of the Ría as a primary source of $\mathrm{C}_{\mathrm{T}}$ and $\mathrm{N}_{\mathrm{T}}$ to the water column, since $\mathrm{C}_{\mathrm{T}}$ and $\mathrm{N}_{\mathrm{T}}$ production exceeded organic matter consumption. The oxygen consumption and the silicate and phosphate production reported in the present work also support the key role of pelagic sediments during downwelling events. These results are in agreement with the general statement that continental shelf sediments over-world play a key role in nutrient mineralization processes (Rowe et al., 1975; Howarth, 1988; Christensen, 1994).

\subsection{The hydrodynamic control of NEP in an estuarine upwelling ecosystem}

The NEP of the Ría de Arousa depends strongly on the water column response to the variability of shelf wind-stress, as usually observed in coastal upwelling systems. The high productivity and the coupling of the circulation in the embayment with coastal upwelling make the Ría de Arousa an ideal scenario to parameterise the effect of the external forces on the productivity.

Coastal upwelling affects the productivity of the embayment in two contrasting ways. The average $I_{\mathrm{W}}$ during the 6-7 days before any of the short periods (3-4 days) considered ('previous upwelling', $I \mathrm{w}_{12}$ ) enhances the productivity because of the introduction of nutrient-rich ENACW into the embayment. On the contrary, the average $I_{\mathrm{W}}$ during the study periods ('instantaneous upwelling', $I \mathrm{w}_{0}$ ) depresses the productivity of the system because of the concomitant reduction of the residence time within the embayment. This 'washing-out effect does not allow the new phytoplankton population in the upwelled water to adapt to the new light conditions (Zimmerman et al. 1987). Since the coefficient of $I \mathrm{w}_{0}$ is a half of the coefficient of $I \mathrm{w}_{12}$, an 'instantaneous upwelling' of the same order than the 'previous 
upwelling' will be able to reduce the productivity by a half. The combination of $I \mathrm{w}_{0}$ and $I \mathrm{w}_{12}$ constitutes $\sim 43 \%$ of the explained variance.

The heat-exchange flux across the sea surface contribute positively to the productivity of the embayment in two manners. $F_{Q_{1}}$ increases the thermal stability of the water column during the 3-4 days before the short periods considered, which contributes to reduce the 'washing-out' effect associated to $I \mathrm{w}_{12}$. The combination of high $I \mathrm{w}_{12}$ and high $F \mathrm{Q}_{1}$ produces a quite favourable situation in which nutrients are injected by upwelling and the light-adapted phytoplankton population in the photic layer is not 'washed out' and replaced by the new population transported by the upwelled water (Huntsman and Barber, 1977). In addition, FQ is related to the availability of light for phytoplankton growth during the short study periods since the formulae used to calculate $F_{\mathrm{Q}}$ includes the day-length an a correction for cloudiness. $\mathrm{FQ}_{0}$ and $\mathrm{FQ}_{1}$ increases to $\sim 80 \%$ the percentage of the explained variance.

The remaining $20 \%$ of the explained variance is achieved when the stability of the water column during the sampling period is considered. $B V$ contributes to reduce the productivity of the system since a well-developed pycnocline prevents the entry of nutrients into the photic layer by turbulent diffusion under non-wind-forced conditions. The same behaviour has been observed by Haapala (1994) in the Gulf of Finland.

\section{Acknowledgements}

The authors wish to thank all the participants in the Galicia- $X$ cruise from the Instituto de Investigacións Mariñas and the crew of the R/V Investigador S., for their valuable help. We are very grateful to S.V. Smith and two anonymous reviewers for their valuable comments and criticisms on the earlier version of the manuscript. Support for this work came from C.I.C.Y.T. Grant No MAR88-0245 and funds from the Conselleria de Pesca da Xunta de Galicia. 


\section{References}

Álvarez-Salgado, X.A., Rosón, G., Pérez, F.F., Pazos, Y., 1993. Hydrographic variability off the Rías Baixas (NW Spain) during the upwelling season. J. Geophys. Res. 98(C8), $14447-14455$.

Álvarez-Salgado, X.A., Rosón, G., Pérez, F.F., Figueiras, F.G., Pazos, Y., 1996a. Nitrogen cycling in an estuarine upwelling system, the Ría de Arousa (NW Spain). I: short-time-scale evolution of hydrodynamic and biogeochemical circulation of nitrogen species. Mar. Ecol. Progr. Ser. 135, 259-273.

Álvarez-Salgado, X.A., Rosón, G., Pérez, F.F., Figueiras, F.G., Ríos, A.F., 1996b. Nitrogen cycling in an estuarine upwelling system, the Ría de Arousa (NW Spain). II. Spatial differences in the short-time-scale evolution of fluxes and net budgets. Mar. Ecol. Prog. Ser. 135, 275-288.

Álvarez-Salgado, X.A., Castro, C.G., Pérez, F.F., Fraga, F., 1997. Nutrient mineralization patterns in shelf waters of the NW Iberian upwelling system. Cont. Self Res. 17, 1247-1270.

Anderson, L.A., 1995. On the hydrogen and oxygen content of marine phytoplankton. Deep-Sea Res. I 42, 1675-1680.

Anderson, L.A., Sarmiento, J.L., 1994. Redfield ratios of mineralization determined by nutrient data analysis. Global Biogeochemical Cycles 8, 65-80.

Antia, N.J., McAllister, C.D., Parsons, T.R., Stephens, R., Strickland, J.D.H., 1963. Further measurements of primary production in coastal sea water using large volume plastic sphere. Limnol. Oceanogr. 6: 237-258.

Bakun, A., 1973. Coastal upwelling indices, west coast of North America 1946-1971. NOAA technical report, NMFSSSRF-671, 103 pp

Blanton, J.O., Tenore, K.R., Castillejo, F.F., Atkinson, L.P., Schwing, F.B., Lavín, A., 1987. The relationship of upwelling to mussel production in the rías on the western coast of Spain. J. Mar. Res. 45, 497-511.

Broecker, W.S., Peng, T.-H, 1982. Tracers in the Sea, Eldigio Press, New York, 690 pp. 
Brzezinski, M.A., 1985. The Si:C:N ratios of marine diatoms: Interspecific variability and the effect of some environmental variables. J. Phycol. 21, 347-357.

Castro, C. G., Pérez F.F., Holley S., Ríos A.F., 1998. Characterization and modelling of water masses in the Northeast Atlantic. Progr. Oceanog., 41(3), 249-279.

Chapman, P., Shannon, L.V., 1985. The Benguela ecosystem, Part II. Chemistry and related processes. Oceanography and Marine Biology Annual Reviews, 23, 183-251.

Copin-Montégut, C. and Copin-Montégut, G., 1983. Stoichiometry of carbon, nitrogen, and phosphorus in marine particulate matter. Deep Sea Res. I, 30: 31-46.

Christensen, J.P., 1994. Carbon export from continental shelves, denitrification and atmospheric carbon dioxide. Cont. Shelf Res. 14, 547-576.

Doval, M.D., Álvarez-Salgado, X.A., Pérez, F.F., 1997. Dissolved organic carbon in an coastal embayment affected by upwelling. Mar. Ecol. Prog. Ser. 157, 21-37.

Eppley R.W., Harrison, W.H., Chisholm, S.W., Stewart, E., 1977. Particulated organic matter in surface water off southern California and its relationship to phytoplankton. J. Mar. Res. 34, 671-696.

Fraga, F., 1981, Upwelling off the Galician Coast, Northwest Spain. In: Coastal Upwelling Series, vol. 1, F.A. Richards, editor, AGU, Washington D.C., pp. 176-182.

Fraga, F., Pérez, F.F., 1990. Transformaciones entre composición química del fitoplancton, composición elemental y relación de Redfield. Scient. Mar. 54, 69-76.

Fraga, F., Pérez, F.F., Figueiras, F.G., Ríos, A.F., 1992, Stoichiometric variations of N, P, C, and $\mathrm{O}_{2}$ during a Gymnodinium catenatum red tide and their interpretation. Mar. Ecol. Prog. Ser. 87, 123-134.

Fraga, F., Ríos, A.F., Pérez, F.F., Figueiras, F.G., 1998. Theoretical limits of oxygen:carbon and oxygen:nitrogen ratios during photosynthesis and mineralisation of organic matter in the sea. Sci. Mar. 62, 161-168.

Friederich, G.E., Codispoti, L.A., 1979. On some factors influencing dissolved silica distribution over the northwest African shelf. J. Mar. Res. 37, 337-353. 
Garber, J.H., 1984. Laboratory study of nitrogen and phosphorus remineralization during the decomposition of coastal plankton and seston. Estuar. Coastal shelf Sci. 18, 685-702.

Haapala, J., 1994. Upwelling and its Influence on nutrient concentration in the coastal area of the Hanko Peninsula, entrance of the Gulf of Finland. Estuar. Coastal Shelf Sci. 38, 507-521.

Harrison, W.G., 1980. Nutrient regeneration and primary production in the sea. In: Falkowski, P.G. (Ed.), Primary Productivity in the Sea, Plenum Press, New York, pp. 433-460.

Howarth, R.W., 1988. Nutrient Limitation of net Primary Production in marine ecosystems. Ann. Rev. Ecol. 19, 89-100.

Huntsman, S.A., Barber, R.T., 1977. Primary production off northwest Africa: the relationship to wind and nutrient conditions. Deep-Sea Res. 24, 25-33.

Jones, P.G.W., 1971. The Southern Benguela Current region in February, 1966: Part. I. Chemical observations with particular reference to upwelling. Deep-Sea Res. 18, 193-208.

Kester D.R., 1975. Dissolved gases other than $\mathrm{CO}_{2}$. In: Chemical Oceanography (Second Edition). Riley J.P. and Skirrow (editors)., 1, 497-556.

Laws, E., 1991. Photosynthetic quotients, new production and net community production in the open ocean. Deep-Sea Res. 38, 143-167.

López-Jamar, E., Cal, R.M., González, G., Hanson, R.B., Rey, J., Santiago, G., Tenore, K.R., 1992. Upwelling and outwelling effects on the benthic regime of the continental shelf off Galicia, NW Spain. J. Mar. Res. 50, 465-488.

Matsukawa, Y., Suzuki, T., 1985. Box model analysis of hydrographic behaviour of nitrogen and phosphorus in a eutrophic estuary. J. Oceanogr. Soc. Japan 41 407-426.

Minster, J.-F., Boulahdid, M., 1987. Redfield ratios along isopycnal surfaces-a complementary study. Deep-Sea Res. 34, 1981-2003.

Millard, R.C., Owens, W.B., Fofonoff, N.P., 1990. On the calculations of the Brunt-Väisälä frequency. Deep-Sea Res. 37, 167-181.

Nelson, D.M., Tréguer, P., Brzezinski, M.A., Leynaert, A., Quéguiner, 1995. Production and dissolution of biogenic silica in the ocean: revised global estimates, comparison with 
regional data and relationship to biogenic sedimentation. Global Biogeochemical Cycles 9, 359-372.

Nogueira, E., Pérez F.F., Ríos A.F., 1997. Seasonal patterns and long-term trends in an estuarine upwelling ecosystem (Ría de Vigo, NW Spain). Estuar. Coastal Shelf Sci. 44. 285-300.

Otto, L, 1975. Oceanography of the Ría de Arousa (NW Spain). Konink Meteor Int Med Verlan 96

Pazos, Y., Figueiras F.G., Álvarez-Salgado X.A., Rosón, G., 1995. The control of succession in red tide species in the Ría de Arousa (NW Spain) by upwelling and stability. In: Lassus P, Arzul G, Erad E, Gentien P, Marcaillou C (eds), Harmful Algal Blooms. Lavoisier, Intercept Ltd, p 645-650.

Pérez, F.F., Mouriño, C., Fraga, F., Ríos, A.F, 1993. Displacement of water masses and remineralization rates off the Iberian Peninsula by nutrient anomalies. J. Mar. Res. 51, 869-892.

Prego, R., 1994. Nitrogen interchanges generated by biogeochemical processes in a Galician ría. Mar. Chem. 45, 167-176.

Prego, R., Bao, R., 1997. Upwelling influence on the Galician coast: silicate in shelf water and underlying surface sediments. Cont. Shelf Res. 17, 307-218.

Redfield, A.C., Ketchum, B.H., Richards, F.A., 1963. The influence of organisms on the composition of sea-water. In: The Sea, vol. 2, M.N. Hill, editor, Wiley and Sons, pp. 26-77.

Ríos, A.F., 1992. El fitoplancton de la Ría de Vigo y sus condiciones ambientales. Ph. D. Thesis. University of Santiago de Compostela, 416 pp.

Ríos A.F., Fraga, F, Pérez, F.F., Figueiras, F.G., 1998. Chemical composition of phytoplankton and particulated organic matter in Ria de Vigo (NW Spain). Sci. Mar. 62, 257-271.

Rosón, G., Álvarez-Salgado, X.A., Pérez, F.F., 1997. A non-stationary box-model to determine residual flows in a partially mixed estuary, based on both thermohaline properties. Application to the Ría de Arousa (NW Spain). Estuar. Coastal Shelf Sci. 44, 249-262. 
Rosón, G., Álvarez-Salgado, X.A., Pérez, F.F., 1999. Carbon cycling in a large coastal embayment, affected by wind-driven upwelling: short-time-scale variability and spatial differences. Mar. Ecol. Prog. Ser. 176, 215-230.

Rosón, G., Pérez, F.F., Álvarez-Salgado, X.A., Figueiras, F.G., 1995. Variation of both thermohaline and chemical properties in an estuarine upwelling ecosystem: Ría de Arousa. l. Time Evolution. Estuar. Coastal Shelf Sci. 41, 195-213.

Rowe, G.T., Clifford, C.H., Smith Jr., K.L., Hamilton, P.L., 1975. Benthic nutrient regeneration and its coupling to primary productivity in coastal waters. Nature 255, 215-217.

Rowe, G.T., Clifford, C.H., Smith Jr., K.L., Hamilton, P.L. 1977. Regeneration of nutrients in sediments off Cape Blanc, Spanish Sahara. Deep-Sea Res. 24, 57-64.

Sambrotto, R.N., Savidge, G., Robinson, C., Boyd, P., Takahashi, T., Karl, D.M., Langdon, C., Chipman, D., Marra, J., Codispoti, L., 1993. Elevated consumption of carbon relative to nitrogen in the surface ocean. Nature 363, 248-250.

Smith, S.V., Hollibaugh, J.T., 1997. Annual cycle and interannual variability of ecosystem metabolism in a temperate climate embayment. Ecological Monographs 67, 509-533.

Sockal, R.R., Rolhf, F.J., 1995. Biometry. Freeman and Company (eds), New York, 887pp

Sverdrup, H.U., Johnson, M.W., Fleming, R.H. 1942. The Oceans, their Physics, Chemistry and General Biology. Prentice-Hall, New York, 1087 pp.

Suess, E., 1981. Phosphate regeneration from sediments of the Perú continental margin by dissolution of fish debris. Geochim. Cosmochim. Acta 45, 577-588.

Takahashi, T., Broecker, W.S., Langer, S., 1985. Redfield ratio based on chemical data from isopycnal surfaces. J. Geophys. Res. 90, 6907-6924.

Tenore, K.R., plus 14 authors, 1982. Coastal upwelling in the Rías Baixas, NW Spain. Contrasting the benthic regimes of the Ría de Arousa and Muros. J. Mar. Res. 40, 701-772.

Tenore, K.R. plus 18 authors (1995) Fisheries and Oceanography off Galicia, NW Spain: Mesoscale spatial and temporal changes in physical processes and resultant patterns of biological productivity. J. Geophys. Res., 100, 10943-10966. 
Treguer, P., Le Corre, P., 1979. The ratios of nitrate, phosphate and silicate during uptake and regeneration phases of the Moroccan upwelling regime. Deep-Sea Res. 26, 163-184.

UNESCO (1985) The international system of units (SI) in oceanography. UNESCO Technical Papers on Marine Science 45, 1-124.

Walsh, J.J., 1991. Importance of continental margins in the marine biogeochemical cycling of carbon and nitrogen. Nature 359, 53-55.

Weis, R.F., 1974. Carbon dioxide in water and seawater: the solubility of a non-ideal gas. Mar. Chem. 2, 203-215.

White, K.K., Dugdale, R.C., 1997. Silicate and nitrate uptake in the Monterey Bay upwelling system. Cont. Shelf Res. 17, 455-472.

Wollast, R., 1991. The coastal organic carbon cycle: Fluxes, sources and sinks. In: Mantoura R.F.C., Martin, J.-M., Wollast, R. (Eds.), Ocean margin processes in global change. J Wiley \& Sons, p 365-381.

Wollast, R., 1993. Interactions of carbon and nitrogen cycles in the coastal zone. In: Wollast R., Mackenzie F.T., Chou L. (Eds), Interactions of C, N, P and S Biogeochemical Cycles and Global Change, Berlin, p 195-210.

Woolf D.K., Thorpe S.A. 1991. Bubbles and the air-sea exchange of gases in near-saturation conditions. J. Mar. Res. 49:435-466

Wooster, W.S., Bakun, A., McClain, D.R., 1976. The seasonal upwelling cycle along the eastern boundary of the North Atlantic. J. Mar. Res. 34, 131-141.

Zimmerman, R.C., Kremer, J.N., Dugdale, R.C., 1987. Acceleration of nutrient uptake by phytoplankton in a coastal upwelling ecosystem: a modelling analysis. Limnol. Oceanogr. 32, 359-367. 


\section{Figure captions}

Fig. 1. Chart of the survey area, the Ría de Arousa (NW Spain), indicating the position of the ten sites where seawater samples were collected. The 20 and 50m isobaths are shown. Lines crossing stations $1,8,7$ and 10 are the boundaries of the study box.

Fig. 2. The 2-D box model. The study box is divided in an upper and a lower layer, separated by a level-of-no-motion, which coincides with the pycnocline. $Q_{\mathrm{x} 1}$ and $Q_{\mathrm{x} 8}$ are the surface horizontal convective flows into the study box from the Ulla and Umia estuaries; $Q_{\mathrm{X} 7}$ is the surface horizontal convective flow from the mouth of the Ría de Arousa to shelf surface waters; $Q_{\mathrm{xo1}}$ and $Q_{\mathrm{xos}}$ are the compensating bottom convective flows from the study box into the Ulla and Umia estuaries; $Q_{\mathrm{x} 07}$ is the compensating bottom flow from the shelf into the lower layer of the study box; $Q_{\mathrm{Z}}$ and $Q_{\mathrm{E}}$ and $M$ are the vertical convective, entrainment and turbulent mixing flows from the lower to the upper layer of the study box; $Q_{\mathrm{R}}+P-E$ is the balance of runoff, precipitation and evaporation in the study box and; $F_{\mathrm{Q}}$ the heat exchange flux across the sea surface.

Fig. 3. Time-course of (a) $\Delta C_{\mathrm{TCOR}}, \Delta N_{\mathrm{T}}, \Delta P$ and $\Delta O_{2 \mathrm{COR}}$ in mmol m $\mathrm{m}^{-2} \mathrm{~d}^{-1}$ of oxygen and (b) $\triangle P O C, \triangle P O N, \triangle P O P$ and $\triangle C h l a$ in $\mathrm{mmol} \mathrm{m}^{-2} \mathrm{~d}^{-1}$ of carbon. The linear equations in Table 3 were used to convert inorganic carbon, nitrogen and phosphorus data into $\mathrm{O}_{2}$ units and organic nitrogen phosphorus and Chla data into carbon units. The solid lines represent the average oxygen $(<N E P>)$ and organic carbon production $(<P O C>)$ obtained from the independent budgets of $\mathrm{C}_{\mathrm{T}}, \mathrm{N}_{\mathrm{T}}, \mathrm{P}$ and $\mathrm{O}_{2}$ and POC, PON, POP and Chla, respectively.

Fig. 4. Short-time-scale (3-4 days) average net production of particulate organic matter versus average net ecosystem production in the study box . Units, mmol m $\mathrm{m}^{-2} \mathrm{~d}^{-1}$ of carbon.

Fig. 5. Time-course of (a) Ekman transport, $I_{\mathrm{W}}$; (b) heat-exchange flux across the sea surface, $F_{\mathrm{Q}}$; (c) average depth-integrated Brunt-Väisälä frequency, $B V$; and (d) average $(<N E P>)$ and modelled net ecosystem production. $B V=\sqrt{\frac{g}{Z / 2}} \cdot \ln \frac{\rho_{L}}{\rho_{U}}$, where $g$ is the gravity 
acceleration, $Z$ is the average depth of the study volume in the Ría de Arousa (23 m) and $\rho_{\mathrm{L}}$ and $\rho_{\mathrm{U}}$ the density of the lower and upper layers, respectively (Millard et al. 1990).

Fig. 6. Average (a) residual flows; (b) inorganic salts and oxygen fluxes; and (c) particulate organic matter fluxes during the upwelling season (June 8 to October 13, 1989). $Q_{\mathrm{X}}, Q_{\mathrm{xo}}$, $Q_{\mathrm{Z}}, Q_{\mathrm{E}}, M_{\mathrm{Z}}$ and $Q_{\mathrm{R}}+P-E$ in $\mathrm{m}^{3} \mathrm{~s}^{-1}$. Nutrient and organic mater fluxes in mol s $\mathrm{s}^{-1}$.

Fig.7. Average (a) residual flows; (b) inorganic salts and oxygen fluxes; and (c) particulate organic matter fluxes during the autumn downwelling (October 13 to 30, 1989). $Q_{\mathrm{x}}, Q_{\mathrm{xo}}$, $Q_{\mathrm{Z}}, Q_{\mathrm{E}}, M_{\mathrm{Z}}$ and $Q_{\mathrm{R}}+P-E$ in $\mathrm{m}^{3} \mathrm{~s}^{-1}$. Nutrient and organic mater fluxes in $\mathrm{mol} \mathrm{s} \mathrm{s}^{-1}$. 
Table 1. Summary of the average concentration of the measured variables during the hydrographic sampling in the Ría de Arousa from 8 June to 30 October 1989in the upper (up) and lower (low) layers of the study box (Fig. 2).

\begin{tabular}{|c|c|c|c|c|c|c|c|c|c|c|c|c|c|c|c|c|c|c|c|c|c|c|c|c|}
\hline \multirow{2}{*}{$\begin{array}{c}\text { Day } \\
\text { of } \\
1989 \\
\end{array}$} & \multicolumn{2}{|c|}{ salinity } & \multicolumn{2}{|c|}{$\begin{array}{c}\text { temperature } \\
\left({ }^{\circ} \mathrm{C}\right)\end{array}$} & \multicolumn{2}{|c|}{$\begin{array}{c}\text { alkalinity } \\
\left(\mu \mathrm{mol} \cdot \mathrm{kg}^{-1}\right)\end{array}$} & \multicolumn{2}{|c|}{$\begin{array}{c}\mathbf{C}_{\mathbf{T}} \\
\left(\mu \mathrm{mol} \cdot \mathrm{kg}^{-1}\right)\end{array}$} & \multicolumn{2}{|c|}{$\begin{array}{c}\mathbf{O}_{2} \\
\left(\mu \mathrm{mol} \cdot \mathrm{kg}^{-1}\right)\end{array}$} & \multicolumn{2}{|c|}{$\begin{array}{c}\text { Chl-a } \\
\left(\mu \mathrm{g} \cdot \mathrm{l}^{-1}\right)\end{array}$} & \multicolumn{2}{|c|}{$\begin{array}{c}\mathbf{H P O}_{4}{ }^{2-} \\
\left(\mu \mathrm{mol} \cdot \mathrm{kg}^{-1}\right)\end{array}$} & \multicolumn{2}{|c|}{$\begin{array}{c}\mathbf{S i}(\mathbf{O H})_{4} \\
\left(\mu \mathrm{mol} \cdot \mathrm{kg}^{-1}\right)\end{array}$} & \multicolumn{2}{|c|}{$\begin{array}{c}\mathbf{N}_{\mathbf{T}} \\
\left(\mu \mathrm{mol} \cdot \mathrm{kg}^{-1}\right)\end{array}$} & \multicolumn{2}{|c|}{$\begin{array}{c}\text { POC } \\
\left(\mu \mathrm{mol} \cdot \mathrm{l}^{-1}\right)\end{array}$} & \multicolumn{2}{|c|}{$\begin{array}{c}\text { POP } \\
\left(\mu \mathrm{mol} \cdot \mathrm{l}^{-1}\right)\end{array}$} & \multicolumn{2}{|c|}{$\begin{array}{c}\text { PON } \\
\left(\mu \mathrm{mol} \cdot l^{-1}\right)\end{array}$} \\
\hline & up & low & up & low & up & low & up & low & up & low & up & low & up & low & up & low & up & low & up & low & up & low & p & low \\
\hline 160 & 35.30 & 35.67 & 2 & .21 & 313 & 2346 & 064 & 126 & 51 & 222 & T. & 1.72 & 0.00 & 0 & 1 & 4.27 & 37 & 6.18 & 8.0 & 0.9 & .30 & 0.12 & 2.74 & 1.37 \\
\hline 163 & 35.30 & 35.60 & 15.47 & 14.03 & 2306 & 2337 & 2035 & 2094 & 279 & 246 & 4.03 & 3.95 & 0.23 & 0.36 & 1.88 & 3.76 & 1.43 & 3.74 & 18.5 & 13.6 & 0.34 & 0.27 & 2.95 & 2.23 \\
\hline 166 & 35.29 & 35.64 & 15.06 & 13.59 & 2308 & 2341 & 2058 & 2112 & 252 & 228 & 2.01 & 0.76 & 0.29 & 0.45 & 4.10 & 5.75 & 2.08 & 6.46 & 16.1 & 10.5 & 0.25 & 0.15 & 2.34 & 1.33 \\
\hline 170 & 35.24 & 35.64 & 16.60 & 13.83 & 2299 & 2340 & 2035 & 2120 & 267 & 224 & 1.31 & 0.89 & 0.24 & 0.53 & 1.51 & 4.71 & 1.48 & 6.80 & 15.8 & 9.6 & 0.23 & 0.15 & 2.00 & 1.51 \\
\hline 173 & 35.09 & 35.59 & 17.89 & 14.32 & 2287 & 2335 & 2015 & 2104 & 273 & 236 & 1.40 & 1.44 & 0.17 & 0.38 & 1.01 & 5.17 & 0.52 & 4.45 & 15.4 & 10.4 & 0.21 & 0.16 & 2.21 & 1.47 \\
\hline 177 & 34.87 & 35.59 & 18.62 & 14.39 & 2263 & 2333 & 2007 & 2121 & 269 & 229 & 1.34 & 1.46 & 0.31 & 0.56 & 2.26 & 5.93 & 1.85 & 6.05 & 16.6 & 10.9 & 0.23 & 0.16 & 2.21 & 1.55 \\
\hline 180 & 34.73 & 35.64 & 17.24 & 13.93 & 2261 & 2341 & 2015 & 2125 & 262 & 222 & 3.16 & 1.27 & 0.38 & 0.51 & 4.39 & 4.73 & 1.45 & 6.68 & 24.0 & 13.2 & 0.32 & 0.18 & 3.43 & 1.78 \\
\hline 184 & 35.40 & 35.70 & 15.38 & 13.41 & 2318 & 2347 & 2067 & | & 28 & 214 & 5.87 & 1.00 & 0.24 & 0.75 & 0.0 & | & 1.48 & 6.67 & 26.3 & (2. & 0.39 & 0.15 & . & 1.71 \\
\hline 187 & 35.26 & 35.66 & 15.84 & 13.74 & 2299 & 2337 & 2050 & 2125 & 265 & 221 & 2.92 & 2.02 & 0.15 & 0.38 & 1.94 & 4.38 & 1.12 & 5.77 & 19.8 & 16.4 & 0.32 & 0.21 & 3.22 & 2.30 \\
\hline 191 & 35.22 & 35.62 & 15.49 & 13.80 & 2297 & 2332 & 2071 & 2124 & 238 & 213 & 3.59 & 1.60 & 0.32 & 0.48 & 5.29 & 5.88 & 2.79 & 6.77 & 17.0 & 13.9 & 0.26 & 0.17 & 2.89 & 2.03 \\
\hline 194 & 35.53 & 35.69 & 14.89 & 13.16 & 2325 & 2340 & 2098 & 2132 & 237 & 207 & 2.43 & 0.66 & 0.42 & 0.58 & 5.78 & 6.09 & 4.41 & 8.79 & 15.4 & 10.1 & 0.23 & 0.12 & 2.48 & 1.34 \\
\hline 198 & 35.55 & 35.70 & 15.60 & 13.28 & 2324 & 2343 & 2040 & 2131 & 289 & 213 & 6.36 & 2.74 & 0.12 & 0.52 & 1.86 & 5.61 & 1.51 & 7.64 & 30.9 & 14.7 & 0.39 & 0.18 & 4.18 & 2.07 \\
\hline 201 & 35.53 & 35.69 & 16.51 & 13.82 & 2320 & 2341 & 2043 & 2127 & $\angle 00$ & 219 & 3.81 & 2.21 & 0.15 & 0.48 & 2.10 & 5.83 & 1.02 & 6.40 & 24.9 & 15.7 & 0.34 & 0.19 & 3.42 & 2.05 \\
\hline 205 & 35.45 & 35.66 & 17.48 & 14.78 & 2311 & 2338 & 2036 & 2115 & 273 & 226 & 2.94 & 1.37 & 0.14 & 0.41 & 2.64 & 6.29 & 0.95 & 5.83 & 21.5 & 13.9 & 0.31 & 0.19 & 2.85 & 1.80 \\
\hline 208 & 35.55 & 35.71 & 15.45 & 13.78 & 2325 & 2343 & 2119 & 2146 & 222 & 203 & 1.76 & 0.64 & 0.45 & 0.53 & 5.99 & 6.13 & 5.27 & 8.52 & 11.2 & 10.4 & 0.17 & 0.14 & 1. & 1.23 \\
\hline 212 & 35.56 & 35.73 & 15.57 & 13.63 & 2329 & 2347 & 2097 & 2149 & 248 & 203 & 7.30 & 1.61 & 0.31 & 0.54 & 3.28 & 6.46 & 3.27 & 8.90 & 23.9 & 12.4 & 0.37 & 0.15 & 3.22 & 1.36 \\
\hline 215 & 35.65 & 35.73 & 14.98 & 13.67 & 2333 & 2346 & 2088 & 2141 & 260 & 208 & 8.09 & 2.19 & 0.27 & 0.52 & 2.10 & 4.99 & 2.87 & 8.49 & 24.6 & 11.9 & 0.38 & 0.16 & 3.62 & 1.54 \\
\hline 219 & 35.64 & 35.73 & 16.17 & 14.34 & 2326 & 2340 & 2061 & 2125 & 278 & 221 & 3.83 & 2.70 & 0.16 & 0.43 & 1.22 & 4.05 & 1.07 & 5.51 & 21.6 & 14.5 & 0.32 & 0.21 & 3.09 & 1.97 \\
\hline 222 & 35.64 & 35.72 & 17.24 & 15.06 & 2330 & 2344 & 2053 & 2115 & 283 & 201 & 1.75 & 0.86 & 0.11 & 0.34 & 1.48 & 3.94 & 0.60 & 3.41 & 16.4 & 11.6 & 0.25 & 0.16 & 2.15 & 1.47 \\
\hline 226 & 35.58 & 35.71 & 18.18 & 14.84 & 2314 & 2342 & 2038 & 2134 & 268 & 209 & 2.00 & 0.96 & 0.10 & 0.47 & 1.81 & 6.82 & 1.03 & 5.27 & 15.6 & 10.0 & 0.29 & 0.15 & 2.23 & 1.50 \\
\hline 229 & 35.45 & 35.70 & 18.89 & 15.35 & 2294 & 2333 & 2025 & 2117 & 256 & 208 & 2.42 & 1.09 & 0.15 & 0.39 & 3.15 & 7.05 & 0.69 & 4.11 & 17.9 & 12.6 & 0.30 & 0.18 & 2.20 & 1.47 \\
\hline
\end{tabular}




\begin{tabular}{|c|c|c|c|c|c|c|c|c|c|c|c|c|c|c|c|c|c|c|c|c|c|c|c|c|}
\hline 23 & 47 & & & 82 & 97 & 34 & 57 & 35 & 38 & 196 & 77 & & 30 & & 38 & .71 & 28 & 95 & 9.9 & 10.3 & .25 & 12 & 2.89 & 24 \\
\hline 236 & .45 & 35.74 & 52 & .00 & 308 & 340 & 991 & 45 & 222 & 92 & 52 & 34 & 47 & 59| & 53 & 7.07 & 23 & 8.18 & .4 & 7.2 & 22 & 07 & .71 & .86 \\
\hline 240 & 60 & .75 & .38 & .90 & 328 & 343 & 108 & 14 & 230 & 196 & 3.08 & 0.68 & 0.37 & 0.54 & 7.76 & 6.96 & .83 & 8.00 & 20.3 & 11.1 & .26 & 10 & 14 & .36 \\
\hline 243 & 63 & .70 & .24 & 63 & 334 & 342 & 069 & 33 & 264 & 208 & 4.79 & 1.15 & .21 & 44 & .03 & 7.34 & 23 & 5.59 & 32.6 & 14.1 & .43 & .16 & .57 & 1.84 \\
\hline 250 & 5.71 & 35.76 & 14.54 & 3.74 & 2337 & 2344 & 2140 & 2149 & 221 & 203 & 1.07 & 0.43 & 0.59 & 0.60 & 8.02 & 7.25 & 8.28 & 9.42 & 11.3 & 10.1 & 0.12 & 0.09 & 1.52 & 1.16 \\
\hline 254 & 61 & .78 & 57 & .64 & 2327 & 345 & 02 & 5 & 238 & 193 & 6.40 & 0.8 & .43 & & 40 & 7.73 & 88 & 9.85 & 3.3 & 9.6 & 33 & 0.11 & .59 & .26 \\
\hline 257 & 35.66 & 35.77 & 14.57 & 3.60 & 2335 & 2347 & 2122 & 2151 & 225 & 195 & 4.44 & 1.48 & 0.50 & 0.67 & 6.28 & 7.58 & 5.68 & 9.36 & 16.4 & 10.1 & 0.26 & 0.13 & 2.84 & 1.52 \\
\hline 268 & 5.54 & 35.74 & 15.74 & 4.44 & 2314 & 2341 & 2058 & 2121 & 271 & 218 & 2.12 & 2.40 & 0.29 & 0.52 & 1.99 & 4.54 & 1.55 & 6.16 & 16.6 & 11.6 & 18 & 0.16 & 90 & 1.53 \\
\hline 271 & .56 & .73 & 15.21 & .32 & 2323 & 342 & 2100 & 13 & 231 & 206 & 2.06 & 1.0 & 0.4 & 0.53 & 3.78 & 4.98 & .74 & 7.08 & 10.6 & 9.3 & 17 & 0.12 & 1.58 & 1.26 \\
\hline 275 & 35.67 & 35.73 & 14.67 & 13.88 & 2331 & 2342 & 2125 & 2145 & 222 & 200 & 2.13 & 0.90 & 0.48 & 0.56 & 5.50 & 6.19 & 5.77 & 8.05 & 13.5 & 9.9 & 0.19 & 0.12 & 1.95 & 1.23 \\
\hline 278 & 5.62 & 35.72 & 15.10 & 4.12 & 2330 & 343 & 2094 & 2138 & 258 & 21 & 4.10 & 2.3 & 0.36 & 0.55 & 3.37 & 4.99 & 2.60 & 6.62 & 18.4 & 12.7 & 0.29 & 0.1 & 2.88 & 1.98 \\
\hline 282 & 5.65 & 35.73 & 14.62 & 4.07 & 2333 & 341 & 2108 & 131 & 238 & 208 & 3.98 & 1.48 & 0.41 & 0.53 & 4.15 & 5.36 & 4.13 & 6.92 & 18.9 & 11.5 & 0.29 & 0.17 & 2.92 & 1.71 \\
\hline 300 & 5.41 & 35.53 & 16.24 & 6.00 & 2325 & 331 & 2084 & 2095 & 237 & 232 & $1 . c$ & 1.08 & 0.2 & 0.30 & 4.07 & 4.10 & 3.4 & 3.54 & 15.6 & 11.2 & 17 & 0.13 & 77 & 1.40 \\
\hline 303 & 35.39 & 35.43 & 16.39 & 16.17 & 2322 & 2322 & 2084 & 2092 & 234 & 228 & 1.67 & 1.14 & 0.48 & 0.51 & 5.09 & 5.37 & 4.41 & 5.02 & 16.4 & 13.1 & 0.17 & 0.13 & 2.34 & 1.80 \\
\hline & 35.44 & 35.68 & 15.87 & 14.16 & 2315 & 39 & 2071 & $1 \angle 0$ & 25 & 217 & 3. & 1.56 & 0 & 0.48 & 3.79 & 5.39 & 2.83 & 6.35 & 18.3 & 11. & 0.27 & 0.1 & 2.68 & 1.59 \\
\hline std & 0.26 & 0.08 & 1.21 & 0.67 & 21 & 6 & 39 & 17 & 20 & 14 & 1.84 & 0.91 & 0.13 & 0.09 & 2.04 & 1.32 & 1.89 & 1.72 & 4.8 & 2.1 & 0.08 & 0.04 & 0.72 & 0.36 \\
\hline
\end{tabular}


Table 2. Analytical error $\left(\varepsilon_{\mathrm{D}}\right)$, vertical gradient $\left(\mathrm{C}_{\mathrm{O}}-\mathrm{C}\right)$, estimated error $\left(\varepsilon_{\Delta \mathrm{C}}\right)$ and percentage of the estimated error relative to the net ecosystem production in table $3\left(\varepsilon_{\Delta \mathrm{C}} / \Delta \mathrm{C}\right)$ for $\mathrm{O}_{2}, \mathrm{C}_{\mathrm{T}}, \mathrm{N}_{\mathrm{T}}$, phosphate, silicate, POC, PON, POP, chlorophyll a, salinity and temperature. $\varepsilon_{\mathrm{D}}$ and $\mathrm{C}_{\mathrm{O}}-\mathrm{C}$ in $\mu \mathrm{M}$ except for $\mathrm{Chl}$ a (ppb), salinity (pss) and temperature $\left({ }^{\circ} \mathrm{C}\right) ; \varepsilon_{\Delta \mathrm{C}}$ in $\mathrm{mol} \mathrm{s}^{-1}$ except for Chla (g $\left.\mathrm{s}^{-1}\right)$, salinity $\left(\mathrm{kg} \mathrm{s}^{-1}\right)$ and temperature $\left({ }^{\circ} \mathrm{Cm}^{3} \mathrm{~s}^{-1}\right)$.

\begin{tabular}{|c|c|c|c|c|c|c|c|c|}
\hline & $\mathbf{N}_{T}$ & $\mathbf{O}_{2}$ & $\mathrm{C}_{\mathrm{T}}$ & $\mathbf{P}$ & $\mathbf{S i}$ & POC & PON & POP \\
\hline & 0.05 & 0.5 & 2 & 0.01 & 0.05 & 0.5 & 0.1 & 0.01 \\
\hline
\end{tabular}

\section{Upwelling season}

$\begin{array}{lcccccccc}\mathbf{C}_{\mathbf{O}}-\mathbf{C} & 3.9 & -38 & 60 & 0.19 & 1.8 & -7.0 & -0.12 & -1.17 \\ \varepsilon_{\Delta \mathrm{C}} & 4.4 & 43.1 & 87.5 & 0.3 & 2.5 & 14.5 & 1.7 & 1.2 \\ \varepsilon_{\Delta \mathrm{C}} / \Delta \mathbf{C}(\%) & 21 & 20 & 60 & 34 & 37 & 34 & 26 & 200\end{array}$

\section{Autumn downwelling}

\begin{tabular}{lcccccccc}
$\mathbf{C}_{\mathbf{O}}-\mathbf{C}$ & 0.8 & -8.5 & 11 & 0.05 & 0.3 & -2.9 & -0.04 & -0.5 \\
$\varepsilon_{\Delta \mathrm{C}}$ & 2.8 & 28.3 & 78.5 & 0.4 & 2.0 & 19.8 & 3.2 & 1.1 \\
$\boldsymbol{\varepsilon}_{\Delta \mathrm{C}} / \Delta \mathrm{C} \mathrm{( \% )}$ & 24 & 24 & 68 & 24 & 17 & 30 & 32 & 169 \\
\hline
\end{tabular}


Table 3. Summary of the linear correlations and the regression equations $(Y=A+B \cdot X$; model II; Sockal and Rolhf, 1995) between nutrients salts consumption and oxygen, Chla and particulate organic matter production rates between consecutive sampling (3-4 days) in the Ría de Arousa during the study period. Units are $\mathrm{mmol} \mathrm{m}^{-2} \mathrm{~d}^{-1}$ (n.s., no significant)

\begin{tabular}{|c|c|c|c|c|c|c|}
\hline \multirow[t]{2}{*}{$\overline{\text { No }}$} & \multicolumn{5}{|c|}{ equation } & \multirow[t]{2}{*}{$\overline{r^{2}}$} \\
\hline & $\bar{Y}$ & \pm err Y & $\mathrm{A}( \pm \operatorname{err} \mathrm{A})$ & B ( \pm errB) & $\bar{X}$ & \\
\hline 1 & $\Delta O_{2 \mathrm{COR}}$ & \pm 44 & $27( \pm 8)$ & $-1.05( \pm 0.06)$ & $\Delta C_{\mathrm{T}}^{\prime} \mathrm{COR}$ & 0.86 \\
\hline 2 & $\Delta O_{2 \mathrm{COR}}$ & \pm 58 & n.s. & $-9.7( \pm 0.8)$ & $\Delta N_{\mathrm{T}}$ & 0.76 \\
\hline 3 & $\Delta O_{2 \mathrm{COR}}$ & \pm 61 & $38( \pm 10)$ & $-142( \pm 14)$ & $\Delta P$ & 0.74 \\
\hline 4 & $\Delta C_{\mathrm{T}}{ }^{\prime} \mathrm{COR}$ & \pm 56 & n.s. & $8.4( \pm 0.8)$ & $\Delta N_{\mathrm{T}}$ & 0.75 \\
\hline 5 & $\Delta N_{\mathrm{T}}$ & \pm 4.9 & $-3.6( \pm 0.8)$ & $15( \pm 1)$ & $\Delta P$ & 0.85 \\
\hline 6 & $\Delta N_{\mathrm{T}}$ & \pm 8 & $-5( \pm 1)$ & $1.4( \pm 0.2)$ & $\Delta S i$ & 0.61 \\
\hline 7 & $\triangle P O C$ & \pm 9 & n.s. & $6.3( \pm 0.2)$ & $\triangle P O N$ & 0.95 \\
\hline 8 & $\triangle P O C$ & \pm 18 & n.s. & $69( \pm 6)$ & $\triangle P O P$ & 0.79 \\
\hline 9 & $\triangle P O C$ & \pm 20 & n.s. & $3.0( \pm 0.3)$ & $\Delta$ Chla & 0.74 \\
\hline
\end{tabular}


Table 4. Average net ecosystem production of corrected $\mathrm{O}_{2}\left(\mathrm{~mol} \mathrm{~s}{ }^{-1}\right)$ corrected $\mathrm{C}_{\mathrm{T}}\left(\mathrm{mol} \mathrm{s}^{-1}\right)$, total inorganic nitrogen $\left(\mathrm{mol} \mathrm{s}^{-1}\right)$, phosphate $\left(\mathrm{mol} \mathrm{s}^{-1}\right)$, silicate $\left(\mathrm{mol} \mathrm{s}^{-1}\right)$, chlorophyll a $\left(\mathrm{g} \mathrm{s}^{-1}\right)$, POC $\left(\mathrm{mol} \mathrm{s}^{-1}\right)$, PON $\left(\mathrm{mol} \mathrm{s}^{-1}\right)$ and POP $\left(\mathrm{mol} \mathrm{s}^{-1}\right.$ ) for the upwelling season (June 8 to October 13, 1989). and the autumn downwelling (October 13 to 30, 1989). The average ratios between variables are show as well.

\begin{tabular}{crrrrrrrrrr}
\hline & $\Delta \mathbf{O}_{2 \mathrm{COR}}$ & $\Delta C_{\mathrm{TCOR}}$ & $\Delta N_{\mathrm{T}}$ & $\Delta P$ & $\Delta S i$ & $\Delta C h l a$ & $\Delta P O C$ & $\Delta P O N$ & $\Delta P O P$ \\
\hline Upwelling & 218 & -147 & -21.3 & -1.00 & -6.7 & 11.8 & 41.5 & 6.6 & 0.62 \\
& & & & & & & & & \\
Downwelling & -118 & 116 & 11.7 & 1.59 & 11.8 & -8.6 & -66.0 & -9.8 & -0.63 \\
& & & & & & & & & \\
\hline
\end{tabular}

\begin{tabular}{cccccccc}
\hline & $\boldsymbol{R}_{\mathrm{C}}$ & $\boldsymbol{R}_{\mathrm{N}}$ & $\boldsymbol{R}_{\mathrm{P}}$ & $\Delta N_{\mathrm{T}} / \Delta P$ & $\Delta N_{\mathrm{T}} / \Delta S i$ & $\Delta P O C / \Delta P O N$ & $\Delta P O N / \triangle P O P$ \\
\hline Upwelling & 1.48 & 10.2 & 218 & 21 & 3.2 & 6.3 & 10.5 \\
Downwelling & 1.02 & 10.0 & 74 & 7.4 & 1.0 & 6.7 & 15.5 \\
\hline
\end{tabular}





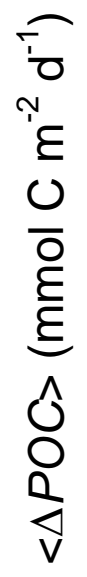

\begin{tabular}{cccc|}
\hline-200 & 0 & 200 & 400 \\
& $<N E P>\left(\mathrm{mmol} \mathrm{C} \mathrm{m}^{-2} \mathrm{~d}^{-1}\right)$
\end{tabular}




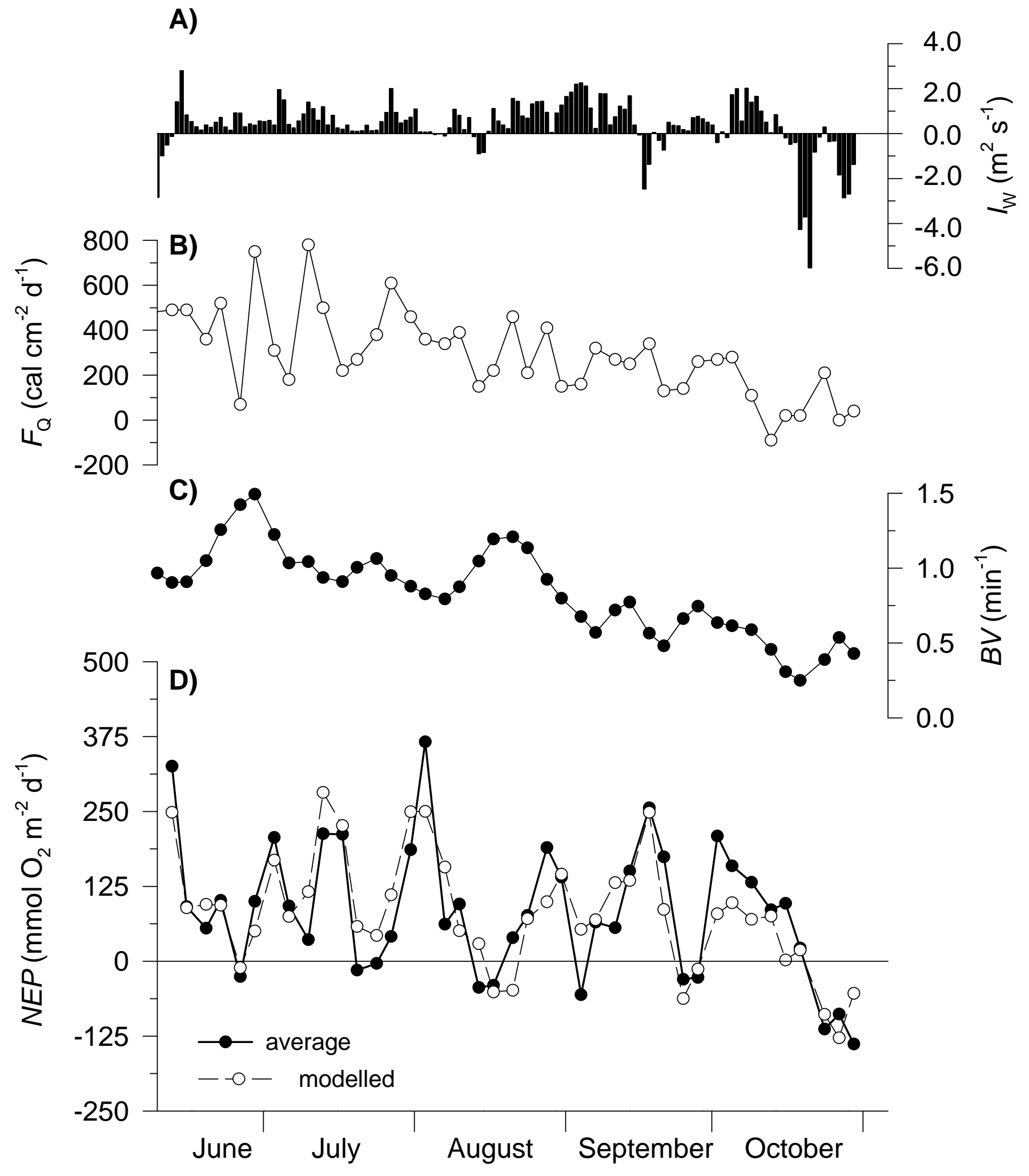


Stoichiometry of the net ecosystem metabolism in a coastal inlet affected by upwelling. The Ría de Arousa (NW Spain)

Fíz F. Pérez $^{\mathrm{a}, *}$, X.A. Álvarez-Salgado ${ }^{\mathrm{a}}$ and Gabriel Rosón ${ }^{\mathrm{b}}$

${ }^{\mathrm{a}}$ Instituto de Investigacións Mariñas, C.S.I.C. Eduardo Cabello 6, Vigo 36208, Spain

${ }^{\mathrm{b}}$ Facultad Ciencias del Mar, Universidad de Vigo, Apartado 874, Vigo 36200, Spain

Submitted to: Marine Chemistry

*Corresponding author. Email: fiz@iim.csic.es 
Abstract. The net uptake of inorganic carbon and nitrogen, phosphate and silicate and the net production of dissolved oxygen and organic carbon, nitrogen and phosphorus have been examined in the Ría de Arousa, a large coastal embayment in the NW Iberian upwelling system. Fluxes and net budgets were estimated with a non-stationary 2-D box model (Rosón et al., 1997) and the distributions of the different species acquired twice a week between May and October 1989 (Rosón et al., 1995). High N/P and N/Si net uptake ratios of 21 and 3.2 were observed during the upwelling season. The rapid recycling of phosphorus compared to nitrogen and the recurrent succession from pioneer diatoms $(\mathrm{Si} / \mathrm{N} \sim 1)$ to red-tide forming species $(\mathrm{Si} / \mathrm{N}=0)$ following the periodic upwelling pulses are the reasons behind the observed ratios. The molar ratios of dissolved oxygen production to inorganic carbon $(-1.48)$ and nitrogen uptake (-10.2) during the upwelling season agree with the Redfield stoichiometry. On the contrary, net nutrient regeneration occurred with $\mathrm{N} / \mathrm{P}, \mathrm{N} / \mathrm{Si}$ and $\mathrm{O}_{2} / \mathrm{C}$ ratios of $7.4,1.0$ and -1.02 during an intense autumn downwelling event. These low ratios are due to the release of an excess of phosphate, silicate and $\mathrm{CO}_{2}$ from the sediments. Conversely, the production of inorganic nitrogen is associated to the consumption of dissolved oxygen following a Redfield ratio of -10.0 . Whereas the $\mathrm{C} / \mathrm{N}$ ratio of the suspended organic matter produced during the upwelling season and consumed during the autumn downwelling event is 6.3-6.7, the N/P ratio changes from 11 during the upwelling season to 15 during the autumn downwelling. About 1/5 of the dissolved oxygen produced during the upwelling season and consumed during the autumn downwelling is delivered to and came from the atmosphere, respectively. Despite the $\mathrm{C} / \mathrm{N} / \mathrm{P} / \mathrm{O}_{2}$ ratios differ from the Redfield values, the high correlation between nutrient salts consumption and dissolved oxygen production $\left(r^{2}=0.74-0.86\right)$ allow to estimate an average net ecosystem production (NEP) from the individual elements. The 3-4 d time-scale variability of the average NEP depends on the two week periodicity of upwelling pulses, the heat exchange across the sea surface and the stability of the water column. As much as $70 \%$ of the total variability can be explained with a linear combination of these parameters. 
Keywords: Nutrients, $\mathrm{CO}_{2}$, net ecosystem production, upwelling, downwelling, Rías Baixas

(NW Iberian upwelling system)

\section{Glossary of terms}

$C_{\mathrm{i}}$

$C_{\mathrm{L}}, C_{\mathrm{U}}$

$C_{\mathrm{R}}$

$C_{\mathrm{T}}$

$D$

$F_{\mathrm{CO} 2}, F_{\mathrm{O} 2}, F_{\mathrm{Q}}$

$F_{\mathrm{E}}$

$F_{\mathrm{Qi}}$

$F_{\mathrm{R}}$

$i-o$

$I-O$

$I_{W}$

$K_{\mathrm{CO} 2}, K_{\mathrm{O} 2}$

$\mathrm{M}_{\mathrm{Z}}$

$B V$

NEP

$<N E P>$

$N_{\mathrm{T}}$

$<P O C>$

$Q_{\mathrm{X}}, Q_{\mathrm{X} 0}, Q_{\mathrm{Z}}$

$Q_{\mathrm{E}}$

$Q_{\mathrm{R}}, P, E$

$R_{\mathrm{C}}, R_{\mathrm{N}}, R_{\mathrm{P}}$

$\Delta$ Chl a

$\Delta C_{\mathrm{TCOR}}$

$\triangle \mathrm{CaCO}_{3}$

$\Delta N_{\mathrm{T}}$

$\Delta O_{2 \mathrm{COR}}$

$\Delta P$

$\Delta S i$

$\triangle P O C, \triangle P O N, \triangle P O P$

$\triangle T A$
Concentration of any species in a convective flow $\left(Q_{\mathrm{x}}, Q_{\mathrm{x} 0}, Q_{\mathrm{z}}\right)$

Concentration of any species in the lower and upper layer of the Ría

Concentration of any species in the river flow $\left(Q_{R}\right)$

Total inorganic carbon concentration

Flux of any species carried by the turbulent diffusion flow $\left(M_{\mathrm{Z}}\right)$

$\mathrm{CO}_{2}, \mathrm{O}_{2}$ and heat fluxes across the sea surface

Flux of any species associated to the 'boundary movement' $\left(Q_{E}\right)$

Flux of any species carried by a convective flow $\left(Q_{\mathrm{X}}, Q_{\mathrm{x} 0}, \mathrm{Q}_{\mathrm{z}}\right)$

Flux of any species carried by the river flow $(R)$

Net daily budget of inputs minus outputs in a box for any species

Average $i$ - $o$ between two consecutive surveys

Upwelling index

Piston velocities for $\mathrm{O}_{2}$ and $\mathrm{CO}_{2}$

Turbulent diffusion flow

Average depth-integrated Brunt-Väisälä frequency

Net ecosystem production, primary production minus community respiration

Average NEP from $\Delta \mathrm{C}_{\mathrm{TCOR}}, \Delta N_{\mathrm{T}}, \Delta \mathrm{P}$ and $\Delta \mathrm{O}_{\mathrm{T} 2 \mathrm{COR}}$

Total inorganic nitrogen (nitrate + nitrite + ammonia) concentration

Average particulate organic matter production from $\triangle P O C, \triangle P O N$ and $\triangle P O P$

Horizontal (upper and lower) and vertical convective flows

Net upward movement of the boundary between upper and lower layer

River flow, precipitation and evaporation rates

$\mathrm{O}_{2}$ production to $\mathrm{C}_{\mathrm{T}}, \mathrm{N}_{\mathrm{T}}$ and $\mathrm{P}$ consumption ratios

Net chlorophyll a production

$\mathrm{CaCO}_{3}$ corrected net $\mathrm{C}_{\mathrm{T}}$ production

Net calcium carbonate fixation

Net $N_{\text {T }}$ production

Ammonia and nitrite corrected net oxygen production

Net phosphate production

Net silicate production

Net particulate organic carbon, nitrogen and phosphorus production

Net total alkalinity production 


\section{Introduction}

The synthesis of the organic tissues of marine phytoplankton in the photic layer of the World Ocean is deeply associated with the consumption of nutrient salts and the production of dissolved oxygen (Redfield et al., 1963). The pioneer $-\mathrm{O}_{2} / \mathrm{C} / \mathrm{N} / \mathrm{P}$ Redfield numbers of 138/106/16/1 have been recently revisited (Anderson, 1995; Fraga et al., 1998), after revision of the biogeochemical composition of marine phytoplankton (Fraga and Pérez, 1990; Laws, 1991). $\mathrm{O}_{2} / \mathrm{CO}_{2} /$ nutrients data have been used to infer the composition of the phytogenic material by examining the resultant stoichiometric ratios during its aerobic oxidation at depth (Takahashi et al., 1985; Minster and Boulahdid, 1987; Anderson and Sarmiento, 1994). However, the stoichiometric ratios obtained from the phytoplankton biochemical composition and from the $\mathrm{O}_{2} / \mathrm{CO}_{2} /$ nutrients data in the upper ocean are not equivalent but complementary. The differences will depend on the relative importance of recycling processes (Sambrotto et al., 1993).

The ratios of nutrient consumption and organic matter production in a given zone are determined by: 1) the actual phytoplankton biochemical composition, which results from the production of primary metabolites in some proportions (Fraga and Pérez, 1990; Laws, 1991; Anderson, 1995, Fraga et al. 1998); and 2) the subsequent utilisation by a particular community of organisms. The disparity between consumption and production intensifies in coastal upwelling regions due to enhanced primary and secondary production rates and acute pelagic and benthic mineralization processes (Rowe et al., 1975; Walsh, 1991; Wollast, 1991; 1993; Christensen, 1994).

The western coast of the Iberian Peninsula experiences upwelling favourable winds during the spring and summer (Wooster et al., 1976; Blanton et al., 1987). In addition to the upwelling of Eastern North Atlantic Central Water (ENACW), the nutrient condition of shelf waters is affected by the organic matter outwelled from the 'Rías Baixas', four large V-shaped coastal indentations (Fraga, 1981; Tenore et al., 1982; 1995; Álvarez-Salgado 1993; 1997). Coastal upwelling forces a 2-D circulation pattern along the main axis of the rías (Otto, 1975). 
The circulation is positive during upwelling events and reversed during the subsequent upwelling relaxations, or under downwelling conditions (Rosón et al., 1997). Nutrients transported by upwelled ENACW into the rías are consumed there at high rates, and part of the produced organic matter is exported to the adjacent shelf (Prego 1994; Rosón et al., 1995; Álvarez-Salgado, 1996a; Doval et al. 1997). As a consequence, extensive accumulation of organic matter (López-Jamar et al., 1992) and opal (Prego and Bao, 1997) occurs in pelagic sediments off the rías.

An intensive research programme was conducted in the Ría de Arousa (NW Spain) and the adjacent shelf from May to October 1989 to quantify the short-time-scale variability on the fluxes of some selected biogeochemical species. The qualitative studies of AlvarezSalgado et al. (1993) and Rosón et al. (1995) demonstrated the key contribution of wind-driven upwelling/downwelling events to the observed distributions of physical and biogeochemical variables either in the Ría and the shelf. The short-time-scale hydrographic variability imposed by the periodic ( $\sim 2$ wk) succession of upwelling/downwelling events precludes the application of the stationary box-model approach to calculate water flows. Therefore, Rosón et al. (1997) developed a 2-D non-stationary mass-heat weighted box-model to calculate water flows in the Ría de Arousa. The calculated flows were positively correlated $(r=+0.67)$ with the Ekman transport, showing enhanced positive circulation during upwelling and reversed circulation during upwelling relaxation and downwelling. Knowledge of water flows allowed Álvarez-Salgado et al. (1996a, 1996b) and Rosón et al. (1999) to set the spatial and short-time-scale variability in the fluxes and net budgets of nitrogen and carbon species. They observed that the net ecosystem production (NEP) of carbon and nitrogen were linked to the Ekman transport, with maximum values after strong upwelling events supported by external nitrate and minimum values after periods of prolonged relaxation, when ammonium accumulated in the Ría. The culture of mussels on hanging ropes - the most intensive over world (Tenore et al. 1982) — had a major impact on carbon and nitrogen biogeochemistry, enhancing the formation of dissolved organic matter. During the 
upwelling season, total inorganic carbon trapped in the Ría (average, $0.95 \mathrm{~g} \mathrm{C} \mathrm{m}^{-2} \mathrm{~d}^{-1}$ ) was distributed between organic (88\%, NEP) and inorganic $\left(12 \%, \mathrm{CaCO}_{3}\right)$ forms. The NEP was mainly exported to the shelf as particulate (25\%) and dissolved (58\%) organic carbon. Carbon and nitrogen biogeochemistry was deeply affected by the strong autumn downwelling event of late October 1989. Net regeneration was dominant all over the Ría (average $-0.66 \mathrm{~g} \mathrm{C} \mathrm{m}^{-2} \mathrm{~d}^{-1}$ ), with an intense release of $\mathrm{CO}_{3} \mathrm{H}^{-}$and $\mathrm{NH}_{4}{ }^{+}$from the sediments (average $0.53 \mathrm{~g} \mathrm{C} \mathrm{m}^{-2} \mathrm{~d}^{-1}$ and $0.10 \mathrm{~g} \mathrm{~N} \mathrm{~m}^{-2} \mathrm{~d}^{-1}$, respectively).

Once the carbon and nitrogen biogeochemistry of the Ría de Arousa during the upwelling season 1989 have been studied in detail, we plan to extend our 2-D non-stationary box-model approach to calculate the NEP of phosphorus, silicon and dissolved oxygen in the present complementary work. Our main objectives here are two. 1) to study the $\mathrm{O}_{2} / \mathrm{C} / \mathrm{N} / \mathrm{P} / \mathrm{Si}$ stoichiometry of the NEP in the Ría de Arousa: how the hydrography affects the deviations from the Redfield ratios?. And 2) to predict the $\mathrm{O}_{2} / \mathrm{C} / \mathrm{N} / \mathrm{P}$ average NEP rates in the Ría de Arousa from the external physical forces acting on the system: could the NEP of a coastal inlet affected by wind-driven upwelling be parametrised using only physical and meteorological variables?

\section{Material and methods}

\subsection{Sampling programme}

Data used in this work were collected from 5 to 7 depths at 10 fixed stations distributed all over the Ría de Arousa (Fig. 1). This programme was repeated 46 times from 12 May to 30 October 1989, which means a survey every 3-4 days. The surface area and volume bounded by stns $1,7,8$ and 10 are $182.4 \mathrm{Km}^{2}$ and $4.203 \mathrm{Km}^{3}$. The remaining $48.5 \mathrm{Km}^{2}$ and $0.060 \mathrm{Km}^{3}$ comprise the innermost part of the ría: the estuaries of the rivers Ulla and Umia. Salinity, dissolved oxygen, 5-nutrients, $\mathrm{pH}$, total alkalinity (TA), chlorophyll and particulate organic matter (carbon, nitrogen and phosphorous) were determined by the methods described in Rosón et al. (1995) and Álvarez-Salgado et al. (1996a). Total inorganic carbon $\left(\mathrm{C}_{\mathrm{T}}\right)$ and 
partial pressure of $\mathrm{CO}_{2}$ at the sea surface $\left(\mathrm{pCO}_{2}\right)$ were calculated from $\mathrm{pH}$ and TA with the equations of the thermodynamic equilibrium of the $\mathrm{CO}_{2}$ system. In addition, daily data of wind over the shelf, river flows $\left(Q_{R}\right)$, and precipitation rates $(P)$ were obtained from the Meteorological observatory at Cape Finisterre, the gauge stations at the rivers Ulla and Umia and the meteorological observatory at Vilagarcía de Arousa, respectively.

\subsection{Variables derived from collected data}

The Ekman transport $\left(I_{\mathrm{W}}\right.$, in $\left.\mathrm{m}^{2} \mathrm{~s}^{-1}\right)$ was calculated from Cape Finisterre wind data following the method of Bakun (1973). The evaporation (E) was obtained with the empirical formulae of Otto (1975) for the Ría de Arousa. The heat exchange flux across the sea surface $\left(F_{\mathrm{Q}}\right)$ was evaluated with the Mosby's formulae (Sverdrup et al., 1942), considering the cloudiness, the back radiation and the evaporation rates (Rosón et al., 1997).

Carbon and dissolved oxygen budgets must include $\mathrm{CO}_{2}$ and $\mathrm{O}_{2}$ exchange with the atmosphere. Following Woolf and Thorpe (1991), $\mathrm{CO}_{2}$ fluxes across the sea surface $\left(\mathrm{FCO}_{2}\right.$, in mol s${ }^{-1}$ ) were calculated by Rosón et al. (1999) using the equation:

$$
F_{\mathrm{CO}_{2}}=k_{\mathrm{CO}_{2}} \cdot S_{\mathrm{CO}_{2}} \cdot\left(p C \mathrm{O}_{2}-p \mathrm{CO}_{2 \mathrm{ATM}}\right) \cdot \mathrm{A}
$$

where $k \mathrm{CO}_{2}\left(\mathrm{~m} \mathrm{~s}^{-1}\right)$ is the piston velocity, $\mathrm{SCO}_{2}\left(\mathrm{~mol} \mathrm{l}^{-1} \mathrm{~atm}{ }^{-1}\right)$ is the solubility of $\mathrm{CO}_{2}$ in seawater (Weiss 1974), and $A$ is the surface area of the Ría de Arousa. Accordingly, oxygen fluxes $\left(\mathrm{FO}_{2}\right.$, mol s$\left.{ }^{-1}\right)$ were calculated in the present work with the following equation:

$$
F_{O_{2}}=k_{O_{2}} \cdot\left(O_{2 S A T}-O_{2}\right) \cdot A
$$

where $\mathrm{KO}_{2}\left(\mathrm{~m} \mathrm{~s}^{-1}\right)$ is the piston velocity for oxygen, calculated from local wind speed following Kester (1975) and $\mathrm{O}_{2 \mathrm{SAT}}$ is the oxygen concentration at saturation (UNESCO, 1985).

\subsection{Calculation of water flows and species fluxes with the 2-D box model}

Water flows were taken from Rosón et al. (1997). These authors estimated the upper $\left(Q_{\mathrm{X}}\right)$ and lower $\left(Q_{\mathrm{x} 0}\right)$ horizontal convective flows, the vertical convective $\left(Q_{\mathrm{Z}}\right)$ and diffusive $\left(M_{\mathrm{Z}}\right)$ flows and 'boundary movement' $\left(Q_{\mathrm{E}}=d V / d t\right)$ in the Ría de Arousa from May to October 
1989 with a 2-D non-stationary salt-heat weighted box model (Fig. 2). $Q_{\mathrm{E}}$ is due to time-changes in the layer volumes (V), associated to the net vertical displacement of the boundary between the upper and lower. The inputs to the model are: 1) the profiles of salinity and temperature at the 10 sampling sites; 2) $Q_{\mathrm{R}}+P-E$ and $F_{\mathrm{Q}}$; and 3) the geometry of the Ría (surface and cross areas, volumes), obtained from accurate charts published by the Spanish 'Instituto Geográfico de la Marina’.

Knowledge of water flows and average concentrations of the different species of every study element in the upper and lower volumes and cross areas considered (Table 1), allow us to obtain species fluxes and net budgets. The flux of any chemical species $\left(F_{\mathrm{Qi}}\right)$ transported by a convective water flow $\left(Q_{\mathrm{i}}\right)$ is the product of flow times concentration $\left(C_{\mathrm{i}}\right): F_{\mathrm{Qi}}=Q_{\mathrm{i}} \cdot C_{\mathrm{i}}$. The river flux is $F_{\mathrm{R}}=Q_{\mathrm{R}} \cdot C_{\mathrm{R}}$, with $C_{\mathrm{R}}$ the concentration in the river flow. The vertical diffusive flux is $D=M_{\mathrm{Z}} \cdot\left(C_{\mathrm{L}}-C_{\mathrm{U}}\right)$, being $C_{\mathrm{L}}$ and $C_{\mathrm{U}}$ the concentrations in the upper and lower layer, respectively. The 'boundary movement' flux is $F_{\mathrm{E}}=C \cdot d V / d t$. Finally, $F_{\mathrm{ATM}}$ is the $\mathrm{CO}_{2}$ or $\mathrm{O}_{2}$ air-sea exchange flux, taken from Rosón et al. (1999) and calculated from eq (2) respectively. Concentrations are in $\mathrm{mol} \mathrm{m}^{-3}$, water flows in $\mathrm{m}^{3} \mathrm{~s}^{-1}$ and species fluxes in $\mathrm{mol} \mathrm{s} \mathrm{s}^{-1}$.

The budget of inputs and outputs (i-o, in $\left.\mathrm{mol} \mathrm{s}^{-1}\right)$ of any species in the Ría results from accumulation, $\partial(C \cdot V) / \partial t$, and biogeochemical processes, $\delta C$ (positive, production; negative, consumption). Therefore:

$$
\begin{aligned}
& i-o=Q_{\mathrm{R}} \cdot C_{\mathrm{R}}+Q_{\mathrm{XO} 7} \cdot C_{\mathrm{O} 7}+Q_{\mathrm{X} 1} \cdot C_{1}+Q_{\mathrm{X} 8} \cdot C_{8}-Q_{\mathrm{X} 7} \cdot C_{7}-Q_{\mathrm{XO} 1} \cdot C_{\mathrm{O} 1}-Q_{\mathrm{XO} 8} \cdot C_{\mathrm{O} 8}-F_{\mathrm{ATM}} \\
& \delta C=\frac{\partial(C \cdot V)}{\partial t}-(i-o)
\end{aligned}
$$

The average $\delta C$ between surveys $\mathrm{j}-1$ and $\mathrm{j}\left(\Delta C\right.$, in $\left.\mathrm{mol} \mathrm{s}^{-1}\right)$ can be obtained by integrating Eq. (4): 


$$
\Delta C=\frac{\int_{t_{j-1}}^{t_{j}} \delta C d t}{t_{j}-t_{j-1}}=V \cdot \frac{C_{t}-C_{t-1}}{t_{t}-t_{t-1}}-\frac{\int_{t_{j-1}}^{t_{j}}(i-o) \cdot d t}{t_{t}-t_{t-1}}
$$

Average $i-o$ between surveys $\mathrm{j}-1$ and $\mathrm{j}$ was calculated assuming linear changes from $t_{\mathrm{j}-1}$ to $t_{\mathrm{j}}$ of 1) salinity, temperature, $Q_{\mathrm{R}}+P-E, F_{\mathrm{Q}}$ and $V$, for calculating water flows and 2) $C, C_{\mathrm{i}}$ and $C_{\mathrm{R}}$ for calculating fluxes. Finally, values of $\Delta C$ in mol s${ }^{-1}$ are converted to $\mathrm{mmol} \mathrm{m}^{-2} \mathrm{~d}^{-1}$ multiplying by the factor 0.474 , which considers the surface area of the Ría de Arousa (182.4 $\left.\mathrm{Km}^{2}\right)$. The budget of any species in the upper layer would require to consider the river flux $\left(F_{\mathrm{R}}\right)$ the inward and outward horizontal convective fluxes $\left(F_{\mathrm{Qx} 1}, F_{\mathrm{Qx} 8}, F_{\mathrm{Qx} 7}\right)$, the three vertical fluxes ( $F_{\mathrm{Qz}}, F_{\mathrm{E}}$ and $D$ ) and $F_{\mathrm{ATM}}$. The budget for the lower layer can be obtained by subtracting the budget of the upper layer form the budget of the box.

Fluxes and net budgets of nitrogen and carbon species were taken from Álvarez-Salgado et al. (1996a) and Rosón et al. (1999) respectively, who described the method above in more detail. Oxygen, phosphorus, silicon and chlorophyll fluxes and budgets were calculated for the present work.

\subsection{Error in the calculation of species fluxes and budgets}

Rosón et al. (1997) reported average \pm std errors of $0.002 \pm 0.029$ pss and $0.012 \pm 0.387^{\circ} \mathrm{C}$ produced by the 2-D non-stationary box model on the salinity and temperature budgets respectively. These errors represent a $<1 \%$ error on water fluxes when compared with the average vertical gradients of salinity $(0.234 \mathrm{pss})$ and temperature $\left(1.7^{\circ} \mathrm{C}\right)$. However the standard deviation of errors represents $10-20 \%$ of the average gradient, producing the corresponding errors in the water flows. The time course of the thermohaline and chemical fields are strongly coupled (Table 1) in response to the succession of upwelling/downwelling events (AlvarezSalgado et al. 1993, Rosón et al. 1995). Therefore, it must be expected that the average error in species budgets are similar to the average errors in salinity and temperature. 
It is possible also to derive the error in water and species fluxes and budgets associated to the precision on the determination of the variables contributing to the calculation of fluxes and budgets. Since the density gradients in the Ría de Arousa during the study period are mainly (85\%) controlled by temperature, the error of the 2-D box model during the estimation of $Q_{\mathrm{X}}$ $\left(\varepsilon_{q}\right)$ can be determined as:

$\varepsilon_{q}=\frac{\varepsilon_{R} \cdot\left(\bar{T}_{I}-T_{R}\right)+\varepsilon_{D}+\varepsilon_{H}+2 \cdot \varepsilon_{T} \cdot\left(\left|Q_{X}\right|+Q_{R}\right)}{\bar{T}_{I}-\bar{T}_{O}}$

where $\varepsilon_{R}$ is the error in the river flows $\left( \pm 0.5 \mathrm{~m}^{3} \mathrm{~s}^{-1}\right), T_{R}$ is the average river temperature, $\varepsilon_{D}$ is the error in the estimation of the heat exchange across the sea surface $\left( \pm 3 \cdot 10^{9} \mathrm{cal} \mathrm{s}^{-1}\right), \varepsilon_{D}$ is the error in the estimation of the heat content change of the Ría de Arousa $\left(V \cdot 2 \varepsilon_{T} /\left(t_{j}-t_{j-1}\right)=\left(4.2 \cdot 10^{9} \cdot 0.02 / 3.5 \cdot 86400\right)= \pm 278{ }^{\circ} \mathrm{C} \mathrm{m}^{3} \mathrm{~s}^{-1}\right)$ and $\varepsilon_{T}$ is the error of temperature measurements $\left(0.01^{\circ} \mathrm{C}\right)$. The average $Q_{\mathrm{x}}, Q_{\mathrm{R}}$ and the vertical gradient of temperature are $3300 \mathrm{~m}^{3} \cdot \mathrm{s}^{-1}, 27 \mathrm{~m}^{3} \cdot \mathrm{s}^{-1}$ and $1.7^{\circ} \mathrm{C}$, respectively. So, the average $\varepsilon_{q}$ is $\pm 210 \mathrm{~m}^{3} \cdot \mathrm{s}^{-1}$, equivalent to $6 \%$ of $Q_{\mathrm{X}}$.

Considering the conservation of volume $\left(Q_{\mathrm{X}}=Q_{\mathrm{XO}}+R\right)$ and the very low contribution of continental runoff to the error calculation of species budgets, equation (3) can be simplified as:

$i-o=Q_{\mathrm{XO} 7} \cdot\left(C_{\mathrm{O} 7}-C_{7}\right)-Q_{\mathrm{XO} 1} \cdot\left(C_{\mathrm{O} 1}-C_{1}\right)-Q_{\mathrm{XO} 8} \cdot\left(C_{\mathrm{O} 8}-C_{8}\right)-F_{\mathrm{ATM}}$

After replacement of eq. (3) by eq. (7) in eq. (4) and (5) the resulting error of any species budget $\left(\varepsilon_{\Delta C}\right)$ is:

$$
\varepsilon_{\Delta C}=V \cdot \frac{2 \varepsilon_{C}}{\left(t_{j}-t_{j-1}\right)}+2 \varepsilon_{C} \sum_{i=1,7,8} Q_{i}+\overline{(C o-C)} \cdot \sum_{i=1,7,8} \varepsilon_{q}+\varepsilon_{F a t m}
$$

where $\varepsilon_{C}$ is the analytical error of the species (Table 2), $\varepsilon_{\text {Fatm }}$ is the error of flux exchange for $\mathrm{CO}_{2}\left( \pm 0.2 \mathrm{~mol} \mathrm{~s}^{-1}\right)$ and $\mathrm{O}_{2}\left( \pm 1 \mathrm{~mol} \mathrm{~s}^{-1}\right)$, and $\overline{\mathrm{Co}-\mathrm{C}}$ is the average vertical gradient in the volume bounded by stns $1,8,7$ and 10 (Table 1). The average estimated error for the 
upwelling season and the autumn downwelling are shown in Table 2. These errors for $\mathrm{O}_{2}, \mathrm{~N}_{T}$, phosphate and silicate are $20-30 \%$ of $\Delta \mathrm{C}$ for both the upwelling and downwelling periods. The estimated average error for $\Delta C_{\mathrm{T}}$ is about $60-70 \%$, due to the high $\varepsilon_{\mathrm{C}} /\left(C_{\mathrm{O}}-C\right)$ ratio for $\mathrm{C}_{\mathrm{T}}$ compared with the other species. However, these large error estimations are in contradiction with the high correlations of $\Delta C_{\mathrm{T}}$ with $\Delta \mathrm{O}_{2}$ and $\Delta N_{\mathrm{T}}$ (Table 3) suggesting that the proper error of $\Delta \mathrm{C}$ for any species have to be much lower than the errors estimated in Table 2. A similar reasoning can be applied to the particulate organic matter budgets. Following Matsukawa and Suzuki (1985) 'this is probably because the terms and properties involved in the calculations are so many that the averaging effect acting on the independent errors become large enough to decrease the real errors considerably'. So, the real contribution of the analytical error is probably much lower than expected from eq. (8).

\section{Result}

\subsection{Coupling between $\mathrm{O}_{2}, C, N, P$ and Si species net production rates}

The net consumption of total inorganic carbon $\left(\Delta C_{\mathrm{T}}\right)$, total inorganic nitrogen $\left(\Delta N_{\mathrm{T}}\right)$ and phosphate $(\Delta P)$ is compared with the net production of oxygen $\left(\Delta \mathrm{O}_{2}\right)$, obtained solving eq. (5) for the chemical species considered (Table 3). $\Delta C_{\mathrm{T}}$ (Rosón et al., 1999) and $\Delta \mathrm{O}_{2}$ have to be corrected previously. The contribution of calcium carbonate fixation $\left(\triangle \mathrm{CaCO}_{3}\right)$, not related to $\mathrm{O}_{2}$ production, have to be subtracted from $\Delta C_{\mathrm{T}}$. For deep ocean waters $\Delta \mathrm{CaCO}_{3}=$ $-1 / 2 \cdot\left(\Delta \mathrm{TA}+\Delta \mathrm{NO}_{3}{ }^{-}\right)$(Broecker and Peng, 1982; Takahashi et al., 1985). However, for coastal and estuarine waters the contribution of nitrite and ammonium have to be considered as well (Fraga et al., 1992):

$$
\Delta C_{\mathrm{TCOR}}=\Delta C_{\mathrm{T}}+\Delta \mathrm{CaCO}_{3}=\Delta C_{\mathrm{T}}-1 / 2 \cdot\left(\Delta \mathrm{TA}+\Delta N \mathrm{NO}_{3}{ }^{-}+0.45 \cdot \Delta N \mathrm{NO}_{2}^{-}-\Delta N H_{4}{ }^{+}\right)
$$

The amount of $\mathrm{O}_{2}$ produced during the synthesis of phytogenic organic matter depend on the inorganic nitrogen source (nitrate, nitrite or ammonium). The synthesis from nitrate produce 0.5 and 2 moles of $\mathrm{O}_{2}$ per mol of $\mathrm{N}$ consumed more than from nitrite and ammonium, 
respectively. Therefore, in order to compare $\Delta N_{\mathrm{T}}$ with $\Delta \mathrm{O}_{2}$, it is necessary to refer $\Delta \mathrm{O}_{2}$ to an unique nitrogen source (Smith and Hollibaugh, 1997). We have used nitrate as reference to compare with the stoichiometric ratio $R_{\mathrm{N}}\left(=-\Delta \mathrm{O}_{2} / \Delta N \mathrm{O}_{3}^{-}\right)$for deep ocean waters (Minster and Buholahdid, 1987). Following Fraga et al. (1992):

$\Delta O_{2 \mathrm{COR}}=\Delta \mathrm{O}_{2}-0.5 \cdot \Delta N \mathrm{O}_{2}^{-}-2 \cdot \Delta N H_{4}^{+}$

Since $\Delta P$ and $\Delta C_{\mathrm{TCOR}}$ are associated to the net consumption of the three nitrogen forms, it is necessary to use $\Delta O_{2 \mathrm{COR}}$ to compare with the corresponding stoichiometric ratios $R_{\mathrm{P}}$ $\left(=-\Delta O_{2} / \Delta P\right)$ and $R_{\mathrm{C}}\left(=-\Delta O_{2} / \Delta C_{\mathrm{T}}\right)$. The recently revised $-\mathrm{O}_{2} / \mathrm{C} / \mathrm{N} / \mathrm{P}$ Redfield ratios are 149/106/16/1 (Anderson, 1995; Fraga et al., 1998), yielding a reference values of $R_{\mathrm{C}}, R_{\mathrm{N}}$ and $R_{\mathrm{P}}$ of $1.41,9.31$ and 149 respectively.

The direct correlation of $\Delta C_{\mathrm{TCOR}}, \Delta N_{\mathrm{T}}$, and $\Delta P$ with $\Delta O_{2 \mathrm{COR}}$ is $r^{2}=0.74-0.86$ (model II; Sockal and Rolhf, 1995), indicating a strong coupling between the consumption of nutrient salts and the production of dissolved oxygen at the short time scale (3-4 days). The calculated slopes (Table 3) are on a par with the stoichiometric ratios $R_{\mathrm{C}}, R_{\mathrm{N}}$ and $R_{\mathrm{P}}$. Whereas our $R_{\mathrm{N}}$ value of $9.7 \pm 0.8$ agrees with the values usually obtained during the mineralization of organic matter in oxic conditions, our $R_{\mathrm{P}}$ of $142 \pm 14$ is in the low end of the wide range reported in the literature (Redfield et al., 1963; Takahashi et al., 1985; Minster and Boulahdid, 1987; Pérez et al., 1993; Anderson and Sarmiento, 1994; Anderson, 1995; Castro et al., 1998). On the other hand, our $R_{\mathrm{C}}$ of $1.05 \pm 0.06$ is rather low compared with the revised Redfield value. Although the y-intercept of the regression between $\Delta O_{2 \mathrm{COR}}$ and $\Delta N_{\mathrm{T}}$ is not significantly different from zero, the corresponding regressions with $\Delta C_{\mathrm{TCOR}}$, and $\Delta P$ indicate a significant $\mathrm{CO}_{2}$ and $\mathrm{HPO}_{4}{ }^{2-}$ production (i.e. mineralization) of 26 and $0.27 \mathrm{mmol} \mathrm{m}^{-2} \mathrm{~d}^{-1}$ at $\Delta O_{2 \mathrm{COR}}=0$. These figures represent $\sim 30 \%$ and $20 \%$ of the total variability in $\Delta C_{\mathrm{TCOR}}$ and $\Delta P$, respectively.

The correlations between $\Delta C_{\mathrm{TCOR}}, \Delta N_{\mathrm{T}}$, and $\Delta P$ are very high as well $\left(r^{2}=0.75-0.85\right)$ with a N/P ratio of $15 \pm 1$ and a C/N ratio of $8.4 \pm 0.8$ — well above the Redfield value of 6.6 , in agreement with the low $R_{\mathrm{C}}$ obtained. On the other hand, the correlation between $\Delta S i$ and $\Delta N_{\mathrm{T}}$, is 
much lower $\left(r^{2}=0.61\right)$, as silicate is only consumed by diatoms. The slope of the correlation gives a $\mathrm{N} / \mathrm{Si}$ ratio of $1.4 \pm 0.2$, higher than the world average $\mathrm{N} / \mathrm{Si} 1 / 1$ ratio of marine diatoms (Nelson et al., 1995). In addition, the y-intercept denote net mineralization of $3.6 \mathrm{mmol} \mathrm{m}^{-2} \mathrm{~d}^{-1}$ of silicate at $\Delta N_{\mathrm{T}}=0$, which represents about $30 \%$ of the total variability of $\Delta S i$.

The net production of suspended organic carbon $(\triangle P O C)$, nitrogen $(\triangle P O N)$, phosphorous $(\triangle P O P)$ and chlorophyll ( $\triangle$ Chla) can be obtained by solving eq. (5) for all these organic substances. The time evolution of the different organic components are coupled at the short-time scale $\left(r^{2}=0.74-0.96\right)$. The $y$-intercept of the corresponding regression equations is not significantly different from zero (Table 3). The slope of the $\triangle P O C-\triangle P O N$ regression (6.3 \pm 0.2 ) agrees very well with the Redfield $\mathrm{C} / \mathrm{N}$ ratio for healthy phytoplankton, and it is $\sim 25 \%$ lower than the $\mathrm{C} / \mathrm{N}$ ratio of nutrients consumption. On the contrary, the corresponding $\mathrm{C} / \mathrm{P}$ ratio is $69 \pm 6$, about half of the $\Delta C_{T \mathrm{COR}} / \Delta P$ ratio of $135\left(=\mathrm{R}_{\mathrm{P}} / \mathrm{R}_{\mathrm{C}}\right)$. The slope of the $\Delta P O C-\Delta C h l a$

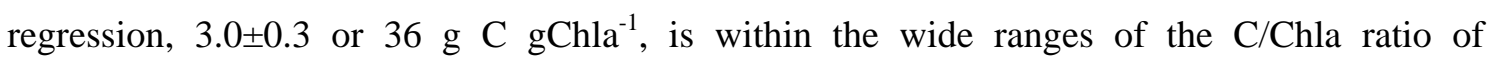
phytogenic organic matter reported in the literature (Antia et al., 1963; Ríos, 1992). A ratio of 40 is commonly used to convert chlorophyll to carbon in cultures of healthy phytoplankton (Eppley et al., 1977). The C/Chla ratio for diatoms species in the adjacent Ría de Vigo ranges from 35 to 50 (Ríos et al., 1998) and a value of 41 for diatoms was recorded by Eppley et al. (1977) in the upwelling of California.

\subsection{Contrasting $-\mathrm{O}_{2} / \mathrm{C} / \mathrm{N} / \mathrm{P} / \mathrm{Si}$ ratios under average upwelling and downwelling conditions.}

The upwelling season. The characteristic succession of wind stress-relaxation events during the upwelling season is observed from June 8 to October 12 (Fig. 5a). The average $I_{\mathrm{W}}$ for this period is $0.5 \mathrm{~m}^{2} \mathrm{~s}^{-1}$. As much as $5069 \mathrm{~m}^{3} \mathrm{~s}^{-1}$ of ENACW-rich shelf bottom water enters the ría during the upwelling season (Fig 6a). Half of them go into the upper layer in the vertical convective flow $\left(2540 \mathrm{~m}^{3} \mathrm{~s}^{-1}\right.$ or $\left.1.2 \mathrm{~m} \mathrm{~d}^{-1}\right)$ and the other half penetrate in the estuarine part of the ría, off the study volume. Considering the volume and the residual flows, the average residence time of water within the Ría is $\sim 6.3$ days. Vertical mixing represented $5205 \mathrm{~m}^{3} \mathrm{~s}^{-1}$ or $2.4 \mathrm{~m} \mathrm{~d}^{-1}$, twice the vertical convective flow. 
The average $\Delta C_{\mathrm{TCOR}}, \Delta N_{\mathrm{T}}, \Delta P$ and $\Delta S i$ for the upwelling season (Table 4) represent 1.4, 54, 39 and $25 \%$ of the total input of $\mathrm{C}_{\mathrm{T}}, \mathrm{N}_{\mathrm{T}}$, phosphate and silicate into the ría (Fig. 6b). Therefore, $\mathrm{N}_{\mathrm{T}}$ is the most efficiently trapped nutrient salt during the upwelling season into the Ría. Although the N/P and N/Si molar ratios in the subsurface ingoing flow are 15.5 and 1.46 respectively, they reduce to 10.7 and 0.84 in the surface outgoing flow. This reduction is due to the very high average $\Delta N_{\mathrm{T}}: \Delta P$ and $\Delta N_{\mathrm{T}}: \Delta S i$ (Table 4) compared with the expected values from the average composition of marine phytoplankton, 16 (Anderson, 1995) and 1 (Nelson et al., 1995) respectively. $\mathrm{O}_{2}$ delivered to the atmosphere was $22 \%$ of $\Delta \mathrm{O}_{2 \mathrm{COR}}$ and the remaining $78 \%$ enriches the surface outgoing flow. On the contrary, the $\mathrm{CO}_{2}$ flux to the atmosphere represents only $0.03 \%$ of the $\mathrm{C}_{\mathrm{T}}$ flux into the Ría and $2 \%$ of $\Delta C_{\mathrm{TCOR}}$. The average $R_{\mathrm{C}}$ and $R_{\mathrm{N}}$ are very close to the expected values for autotrophic synthesis of organic matter.

Net mineralization of $35 \%$ of $C_{\mathrm{T}}, 17 \%$ of $N_{\mathrm{T}}, 35 \%$ of phosphate and $57 \%$ of silicate consumed in the upper level occurs in the lower layer during the upwelling season, using $30 \%$ of oxygen produce in the upper layer. Nutrient consumption in the upper layer and mineralization in the lower layer contribute to increase the vertical gradient of nutrients, enhancing the vertical mixing fluxes and modifying the corresponding nutrient ratios. The N/P and N/Si ratios in the upward convective flow are 12.4 and 0.96 respectively. They are lower than in the bottom ingoing flow because of the mineralization ratios in the lower layer. On the contrary, these ratios in the mixing flow are 22 and 2.6 respectively, very close to the average net consumption ratios observed. Finally, the average N/P and N/Si ratios in the three upward flows $\left(Q_{\mathrm{Z}}, M_{\mathrm{Z}}\right.$ and $\left.Q_{\mathrm{E}}\right)$, i.e. the nutrient ratios feeding the phytoplankton population in the upper layer, are 15.8 and 1.4 respectively. Consequently, the large modification of the N/P and N/Si ratios within the ría occurs mainly in the upper layer.

Average $\triangle P O C, \triangle P O N$ and $\triangle P O P$ during the upwelling season (Table 4) represent an increase of 130, 90 and $100 \%$ compared with the corresponding organic loads in the bottom ingoing flow (Fig. 6c). Only 17\% of POC and PON and 6.5\% of POP produced in the upper layer is mineralised in the lower layer. $\triangle P O C$ and $\triangle P O N$ are $\sim 1 / 3$ of $\Delta C_{\mathrm{TCOR}}$ and $\Delta N_{\mathrm{T}}$ 
respectively, whereas $\triangle P O P$ is as much as $\sim 2 / 3$ of $\triangle P$. The average $\triangle P O C: \triangle P O N$ is $\sim 15 \%$ lower than the $\mathrm{C} / \mathrm{N}$ ratio of POM coming from the shelf, in such a way that the $\mathrm{C} / \mathrm{N}$ ratio in the surface outgoing flow is $\sim 8 \%$ lower than in the bottom ingoing flow. Therefore, during the upwelling season the ría is delivering to shelf surface water a large load of nitrogen-rich POM. On the contrary the organic N/P ratio in the bottom ingoing and the surface outgoing flows are quite similar at $\sim 11$. The average $\Delta$ Chla represents $\sim 280 \%$ of the Chla load in the bottom ingoing flow from the shelf.

The autumn downwelling. Intense southerly winds provoked strong downwelling form 13 to 30 of October (Fig $5 \mathrm{a}$ ). The average $I_{\mathrm{W}}$ for this period was $-0.5 \mathrm{~m}^{2} \mathrm{~s}^{-1}$, provoking a pronounced reversal in the circulation with the entry of shelf surface water into the ría (Fig. 7a). The values of $Q_{\mathrm{X} 7}, Q_{\mathrm{z}}$ and $Q_{\mathrm{xO}}$ are strongly negative, leading to a residence time of only 3.7 days in the volume studied. The circulation is still positive in the estuarine part of the ría. The vertical downward $\left(-6 \mathrm{~m} \mathrm{~d}^{-1}\right)$ and mixing $\left(3.4 \mathrm{~m} \mathrm{~d}^{-1}\right)$ flows are extremely high.

The average $\Delta C_{\mathrm{TCOR}}, \Delta N_{\mathrm{T}}, \Delta P, \Delta S i$ for the autumn downwelling are strongly positive, i.e. the hydrodynamic conditions favoured net nutrient mineralization in the volume considered (Table 4). About $21 \%$ of the $\mathrm{O}_{2}$ consumed during this period came from the atmosphere. Conversely, $\sim 8 \%$ of $\Delta C_{\mathrm{TCOR}}$ is lost to the atmosphere because of the very high surface $\mathrm{pCO}_{2}$ levels and the local strong winds (6 $\mathrm{m} \mathrm{s}^{-1}$; Rosón et al, 1999). Although the average $R_{\mathrm{N}}$ is close the revised Redfield value, $R_{\mathrm{C}}, \Delta N_{\mathrm{T}}: \Delta P$ and $\Delta N_{\mathrm{T}}: \Delta S i$ are low. Most of the mineralization occurs in the upper box: 89, 103, 98 and $71 \%$ of $\mathrm{C}_{\mathrm{T}}, \mathrm{N}_{\mathrm{T}}$, phosphate and silicate. As a consequence of the nutrient mineralization ratios, the high N/P ratio in the surface ingoing flow (13.6) decreased to 12.6 in the to the bottom outgoing flow. Conversely, the very low N/Si ratio of 0.69 in the surface ingoing flow increases to 0.93 in the bottom outgoing flow.

The $\triangle P O C: \triangle P O N$ and $\triangle P O N: \triangle P O P$ during the mineralization of the organic matter in the volume studied (Table 4) are close to the Redfield values. Chla entering the ría in the surface incoming flow is mineralised at an average rate of $8.6 \mathrm{~g} \mathrm{~s}^{-1}$, being the $\triangle P O C: \triangle C h l a$ mass ratio as high as 125 . 


\subsection{Parametrising the NEP of the Ría de Arousa}

Since the time courses of $\Delta C_{\mathrm{TCOR}}, \Delta N_{\mathrm{T}}$ and $\Delta P$ are parallel to $\Delta O_{2 \mathrm{COR}}$, we have converted $-\Delta C_{\mathrm{TCOR}},-\Delta N_{\mathrm{T}}$ and $-\Delta P$ into $\mathrm{mmol} \mathrm{m}^{-2} \mathrm{~d}^{-1}$ of $\mathrm{O}_{2}$ (Fig. 3a), using the linear regressions in Table

3. The average net oxygen production rates obtained from the four series of independent values $\left(C_{\mathrm{TCOR}}, N_{\mathrm{T}}, P\right.$ and $\left.\mathrm{O}_{2 \mathrm{COR}}\right)$ can be considered the net ecosystem production of the Ría $(<N E P>$ ), i.e. the primary production minus the respiration of autothrophus and all heterothropus in the volume studied (Smith and Hollibaugh, 1997). In the same way, $\triangle P O N, \triangle P O P$ and $\triangle C h l a$ have been converted into mmol m${ }^{-2} \mathrm{~d}^{-1}$ of POC (Fig. 3b) using the corresponding regressions in table 3 to obtain an average POC production rate $(<P O C>)$. Although the time evolutions are quite parallel, the direct correlation between $<N E P>$ and $<P O C>$ is not so good, $r^{2}=0.58$ (Fig. 4). If $<N E P>$ is converted into carbon units, the slope of the correlation with $<P O C>(0.33)$ indicates that only $1 / 3$ of the NEP is transformed into exportable POC along the study period.

The seven major $<N E P>$ maxima in Fig. 3b (ranging from 200 to $400 \mathrm{mmol} \mathrm{m}^{-2} \mathrm{~d}^{-1}$ ) occur one sampling (3-4 days) after the periodic entries of nutrient-rich ENACW. The time evolution of the Ekman transport $I_{\mathrm{W}}$ (Fig. 5a) — which forces ENACW into the ría - is a succession of peaks (upwelling) and toughs (relaxation) with a periodicity of $14 \pm 4 \mathrm{~d}$ (Álvarez-Salgado et al., 1993). Upwelling relaxations are accompanied by $<N E P>$ minima (ranging from 0 to $-75 \mathrm{mmol} \mathrm{m} \mathrm{d}^{-1}$ ) in between two maxima. Large negative values of $I_{\mathrm{W}}$ at the end of the study period indicate strong downwelling conditions coinciding with the pronounced minimum of $\langle\mathrm{NEP}\rangle=-116 \mathrm{mmol} \cdot \mathrm{m}^{-2} \cdot \mathrm{d}^{-1}$. The stability of the water column (average depth-integrated Brunt-Väisälä frequency, BV) also contribute to module the NEP of the ría: it reduce the vertical diffusive flux of nutrients to the photic layer during upwelling relaxations and increases the efficiency of nutrient uptake by primary producers during upwelling events. As a general trend, $B V$ increases during relaxations and decreases during upwelling or downwelling conditions (Fig. 5c). The observed decreasing trend along the study period $\left(r^{2}=0.64, \mathrm{n}=45, p<0.0001\right)$ is probably associated to the decreasing heat exchange flux $F_{\mathrm{Q}}$ (Fig. 5b). Such a general decreasing trend of $-0.7 \mathrm{mmol} \mathrm{m}^{-2} \mathrm{~d}^{-1}$ is observed in $\langle N E P>$ as 
well $\left(r^{2}=0.27 n=46, p<0.08\right)$. Therefore, we have tried to quantify the influence of upwelling, stability and heat flux on the NEP looking for the linear combination of $I_{\mathrm{W}}, B V$ and $F_{\mathrm{Q}}$ which explains better the time evolution of $\left\langle N E P>\right.$. The best fit $\left(r^{2}=0.70\right)$ was obtained with the equation:

$$
<N E P>=70( \pm 16) \cdot I \mathrm{w}_{12}-35( \pm 14) \cdot I \mathrm{w}_{0}+0.38( \pm 0.06) \cdot\left(F \mathrm{Q}_{0}+F \mathrm{Q}_{1}\right)-(198 \pm 37) \cdot B V
$$

where $B V, I \mathrm{w}_{0}$ and $F_{\mathrm{Q}_{0}}$ are the average Brünt-Väisälä frequency $\left(\mathrm{min}^{-1}\right)$, Ekman transport $\left(\mathrm{m}^{2}\right.$ $\mathrm{s}^{-1}$ ) and heat exchange flux $\left(\mathrm{cal} \mathrm{cm}^{-2} \mathrm{~d}^{-1}\right)$ from $\mathrm{t}_{\mathrm{j}-1}$ to $\mathrm{t}_{\mathrm{j}} ; F_{\mathrm{Q}_{1}}$ is the average $F_{\mathrm{Q}}$ from $\mathrm{t}_{\mathrm{j}-2}$ to $\mathrm{t}_{\mathrm{j}-1}$; and $I \mathrm{w}_{12}$ is the average $I_{\mathrm{W}}$ from $\mathrm{t}_{\mathrm{j}-3}$ to $\mathrm{t}_{\mathrm{j}-1}$. The river input does not contribute significantly to explain the variance of $\langle N E P>$. Fig. $5 d$ compares the $<N E P>$ rates in Fig. 3a with those calculated with eq. 11. It shows the good agreement between the NEP calculated from the time variability of thermohaline and biogeochemical properties, and the NEP parametrised using the external physical forces of the ecosystem (upwelling and irradiance) and the stability of the water column.

\section{Discussion and conclusions}

\subsection{The dramatic effect of hydrography on the $\mathrm{O}_{2} / C / N / P / S i$ stoichiometry of $N E P$}

Pronounced differences have been observed between the N/P ratios of net nutrient uptake and organic matter production during the upwelling season. The average $\Delta N_{\mathrm{T}} / \Delta P$ is $\sim 30 \%$ higher than and the $\triangle P O N / \triangle P O P$ is $\sim 30 \%$ lower than the expected value of 16 during the synthesis of the organic tissues of marine phytoplankton (Laws, 1991; Anderson, 1995; Fraga et al., 1998). Conversely, $R_{\mathrm{N}}$ keeps the expected ratio during phytoplankton production. The well-known longer recycling times of nitrogen compared with phosphorus (Harrison, 1980; Garber, 1984) could explain the high average N/P ratio during the net uptake of $\mathrm{N}_{\mathrm{T}}$ and phosphate in the $\sim 6$ days average residence time within the study volume. The same behaviour has been recorded by Nogueira et al. (1997) in the adjacent Ría de Vigo. In this sense, Treguer and Le Corre (1979), who obtained a N/P ratio of 18.5 during nutrient uptake, observed that phosphorous regeneration is $\sim 30 \%$ faster than nitrogen regeneration mediated by zooplankton 
or animal excretion in the upwelling off Morocco. Conversely, the low N/P ratio of the suspended organic matter produced, concomitant with a Redfield $\mathrm{C} / \mathrm{N}$ ratio, indicates a substantial contribution of detritus colonised by bacteria, which is probably related with the intensive hanging mussel culture. Low N/P ratios in suspended organic matter were observed during an annual cycle in the Ría de Vigo (average, 12.8). Detritus represented 24\% of the suspended material (Ríos et al., 1998). Accordingly, Copin-Montégut and Copin-Montégut (1983) observed very low C/P ratios in suspended organic matter of the NW Africa upwelling system.

The extremely low average $\Delta N_{\mathrm{T}} / \Delta P=7.4$ during downwelling conditions contrasts with the N/P ratio of the mineralised suspended organic matter. The same behaviour was observed by Howarth (1988) in Narragansett Bay, where suspended organic matter enters the sediments with a N/P ratios of 16 , but nutrient are released back to the water column with a ratio of 6 . In addition, the N/P ratio of mineralised nutrients in the NW and SW Africa upwelling systems ranges from 8 to 12 (Jones, 1971; Rowe et al., 1977; Treguer and Le Corre, 1979). Since the $R_{\mathrm{N}}=10.0$ observed in the Ría de Arousa during the downwelling event is within the expected ranges during the oxidation of phytogenic organic matter in oxic conditions, denitrification processes within the sediments seems not to be the reason behind the low $\Delta N_{\mathrm{T}} / \Delta P$. Therefore, the most likely explanations have to be the faster recycling rates of phosphorus within the sediments, or the alternative hypothesis of phosphate release from interstitial water by processes independent of organic matter oxidation (Suess, 1981). The short residence time of upwelled ENACW in the Ría precludes denitrification, which occurs in estuarine system with long residence time as Tomales Bay in the upwelling region of California (Smith and Hollibaugh, 1997).

The average N/Si net uptake ratio during the upwelling season (3.2) was much higher than the expected value from the average composition of marine diatoms ( 1; Brezinski, 1985; Nelson et al., 1995). Pazos et al. (1995) have demonstrated that the periodic wind stress/relaxation sequence selected the microplankton species inside the Ría de Arousa, which 
results in the annual succession from small pioneer diatoms to red-tide species occurring several times during the upwelling season 1989. Therefore, non-siliceous species have a relevant contribution to the phytoplankton population in the ría, which increases the average N/Si ratio. In the upwelling of Monterrey Bay (California), direct measurements of nitrate and silicate uptake yields $\mathrm{N} / \mathrm{Si}$ ratios ranging from 0.8 under upwelling conditions to 10 under nutrient depletion (White and Dugdale, 1997). In the NW Africa upwelling system, Treguer and Le Corre (1979) obtained a very low ratio of 0.33 using a simple water-masses mixing linear model.

The average N/Si net mineralization ratio during the autumn downwelling decreases to 1.0, pointing to the dissolution of the diatom frustules deposited into the Ría de Arousa. Following Chapman and Shannon (1985), the main reason for the silicate increase that they found in shelf bottom waters off Namibia is the dissolution of silica, which has been deposited either as zooplankton faeces or as undigested diatom frustules. In the case of the Rías Baixas, the contribution of the extensive bottom biodeposits generated by mussel cultured on hanging ropes have to be considered as well (Tenore et al., 1982). In this sense, large opal deposits have been observed in shelf sediments of the NW Iberian Peninsula (Prego and Bao, 1997). Álvarez-Salgado et al. (1997) found N/Si mineralization ratios of 1.2-1.5 in shelf waters off the rías and values ranging from 0.7 to 1.2 have been observed in the NW Africa upwelling system (Treguer and Le Corre, 1979; Friedrerich and Codispoti 1979).

The average $\mathrm{C} / \mathrm{N}$ net uptake ratio by the community of organisms into the Ría de Arousa during the upwelling season (6.9) is slightly higher than the average $\mathrm{C} / \mathrm{N}$ net production ratio of suspended organic matter (6.3). Since suspended organic matter represents only $\sim 1 / 3$ of the total $\Delta C_{\mathrm{TCOR}}$ and $\Delta N_{\mathrm{T}}$, the remaining organic matter produced (dissolved and deposited) must have an average C/N ratio of 7.2. Álvarez-Salgado et al. (1996a) and Rosón et al. (1999) reported that $\sim 17 \%$ of the net uptake of $\mathrm{C}_{\mathrm{T}}$ and $\mathrm{N}_{\mathrm{T}}$ sedimented to the bottom and the remaining $50 \%$ was in the form of dissolved organic matter because of the intensive culture of mussels on hanging ropes. On the contrary, the average $\mathrm{C} / \mathrm{N}$ ratio of the nutrients mineralised during 
the autumn downwelling event is as high as 9.9 , whereas the $\mathrm{C} / \mathrm{N}$ ratio of the suspended organic matter mineralised keeps at 6.7. As for the previous cases, diffusion to the water column of $\mathrm{CO}_{2}$ produced during the mineralization of $\mathrm{C}$-rich organic matter deposited in the pelagic sediments of the ría have to be the reason behind the observed inorganic $\mathrm{C} / \mathrm{N}$ ratio. Álvarez-Salgado et al. (1996a) and Rosón et al. (1999) suggested the pelagic sediments of the Ría as a primary source of $\mathrm{C}_{\mathrm{T}}$ and $\mathrm{N}_{\mathrm{T}}$ to the water column, since $\mathrm{C}_{\mathrm{T}}$ and $\mathrm{N}_{\mathrm{T}}$ production exceeded organic matter consumption. The oxygen consumption and the silicate and phosphate production reported in the present work also support the key role of pelagic sediments during downwelling events. These results are in agreement with the general statement that continental shelf sediments over-world play a key role in nutrient mineralization processes (Rowe et al., 1975; Howarth, 1988; Christensen, 1994).

\subsection{The hydrodynamic control of NEP in an estuarine upwelling ecosystem}

The NEP of the Ría de Arousa depends strongly on the water column response to the variability of shelf wind-stress, as usually observed in coastal upwelling systems. The high productivity and the coupling of the circulation in the embayment with coastal upwelling make the Ría de Arousa an ideal scenario to parameterise the effect of the external forces on the productivity.

Coastal upwelling affects the productivity of the embayment in two contrasting ways. The average $I_{\mathrm{W}}$ during the 6-7 days before any of the short periods (3-4 days) considered ('previous upwelling', $I \mathrm{w}_{12}$ ) enhances the productivity because of the introduction of nutrient-rich ENACW into the embayment. On the contrary, the average $I_{\mathrm{W}}$ during the study periods ('instantaneous upwelling', $I \mathrm{w}_{0}$ ) depresses the productivity of the system because of the concomitant reduction of the residence time within the embayment. This 'washing-out effect does not allow the new phytoplankton population in the upwelled water to adapt to the new light conditions (Zimmerman et al. 1987). Since the coefficient of $I \mathrm{w}_{0}$ is a half of the coefficient of $I \mathrm{w}_{12}$, an 'instantaneous upwelling' of the same order than the 'previous 
upwelling' will be able to reduce the productivity by a half. The combination of $I \mathrm{w}_{0}$ and $I \mathrm{w}_{12}$ constitutes $\sim 43 \%$ of the explained variance.

The heat-exchange flux across the sea surface contribute positively to the productivity of the embayment in two manners. $F_{Q_{1}}$ increases the thermal stability of the water column during the 3-4 days before the short periods considered, which contributes to reduce the 'washing-out' effect associated to $I \mathrm{w}_{12}$. The combination of high $I \mathrm{w}_{12}$ and high $F \mathrm{Q}_{1}$ produces a quite favourable situation in which nutrients are injected by upwelling and the light-adapted phytoplankton population in the photic layer is not 'washed out' and replaced by the new population transported by the upwelled water (Huntsman and Barber, 1977). In addition, FQ is related to the availability of light for phytoplankton growth during the short study periods since the formulae used to calculate $F_{\mathrm{Q}}$ includes the day-length an a correction for cloudiness. $\mathrm{FQ}_{0}$ and $\mathrm{FQ}_{1}$ increases to $\sim 80 \%$ the percentage of the explained variance.

The remaining $20 \%$ of the explained variance is achieved when the stability of the water column during the sampling period is considered. $B V$ contributes to reduce the productivity of the system since a well-developed pycnocline prevents the entry of nutrients into the photic layer by turbulent diffusion under non-wind-forced conditions. The same behaviour has been observed by Haapala (1994) in the Gulf of Finland.

\section{Acknowledgements}

The authors wish to thank all the participants in the Galicia- $X$ cruise from the Instituto de Investigacións Mariñas and the crew of the R/V Investigador S., for their valuable help. We are very grateful to S.V. Smith and two anonymous reviewers for their valuable comments and criticisms on the earlier version of the manuscript. Support for this work came from C.I.C.Y.T. Grant No MAR88-0245 and funds from the Conselleria de Pesca da Xunta de Galicia. 


\section{References}

Álvarez-Salgado, X.A., Rosón, G., Pérez, F.F., Pazos, Y., 1993. Hydrographic variability off the Rías Baixas (NW Spain) during the upwelling season. J. Geophys. Res. 98(C8), $14447-14455$.

Álvarez-Salgado, X.A., Rosón, G., Pérez, F.F., Figueiras, F.G., Pazos, Y., 1996a. Nitrogen cycling in an estuarine upwelling system, the Ría de Arousa (NW Spain). I: short-time-scale evolution of hydrodynamic and biogeochemical circulation of nitrogen species. Mar. Ecol. Progr. Ser. 135, 259-273.

Álvarez-Salgado, X.A., Rosón, G., Pérez, F.F., Figueiras, F.G., Ríos, A.F., 1996b. Nitrogen cycling in an estuarine upwelling system, the Ría de Arousa (NW Spain). II. Spatial differences in the short-time-scale evolution of fluxes and net budgets. Mar. Ecol. Prog. Ser. 135, 275-288.

Álvarez-Salgado, X.A., Castro, C.G., Pérez, F.F., Fraga, F., 1997. Nutrient mineralization patterns in shelf waters of the NW Iberian upwelling system. Cont. Self Res. 17, 1247-1270.

Anderson, L.A., 1995. On the hydrogen and oxygen content of marine phytoplankton. Deep-Sea Res. I 42, 1675-1680.

Anderson, L.A., Sarmiento, J.L., 1994. Redfield ratios of mineralization determined by nutrient data analysis. Global Biogeochemical Cycles 8, 65-80.

Antia, N.J., McAllister, C.D., Parsons, T.R., Stephens, R., Strickland, J.D.H., 1963. Further measurements of primary production in coastal sea water using large volume plastic sphere. Limnol. Oceanogr. 6: 237-258.

Bakun, A., 1973. Coastal upwelling indices, west coast of North America 1946-1971. NOAA technical report, NMFSSSRF-671, 103 pp

Blanton, J.O., Tenore, K.R., Castillejo, F.F., Atkinson, L.P., Schwing, F.B., Lavín, A., 1987. The relationship of upwelling to mussel production in the rías on the western coast of Spain. J. Mar. Res. 45, 497-511.

Broecker, W.S., Peng, T.-H, 1982. Tracers in the Sea, Eldigio Press, New York, 690 pp. 
Brzezinski, M.A., 1985. The Si:C:N ratios of marine diatoms: Interspecific variability and the effect of some environmental variables. J. Phycol. 21, 347-357.

Castro, C. G., Pérez F.F., Holley S., Ríos A.F., 1998. Characterization and modelling of water masses in the Northeast Atlantic. Progr. Oceanog., 41(3), 249-279.

Chapman, P., Shannon, L.V., 1985. The Benguela ecosystem, Part II. Chemistry and related processes. Oceanography and Marine Biology Annual Reviews, 23, 183-251.

Copin-Montégut, C. and Copin-Montégut, G., 1983. Stoichiometry of carbon, nitrogen, and phosphorus in marine particulate matter. Deep Sea Res. I, 30: 31-46.

Christensen, J.P., 1994. Carbon export from continental shelves, denitrification and atmospheric carbon dioxide. Cont. Shelf Res. 14, 547-576.

Doval, M.D., Álvarez-Salgado, X.A., Pérez, F.F., 1997. Dissolved organic carbon in an coastal embayment affected by upwelling. Mar. Ecol. Prog. Ser. 157, 21-37.

Eppley R.W., Harrison, W.H., Chisholm, S.W., Stewart, E., 1977. Particulated organic matter in surface water off southern California and its relationship to phytoplankton. J. Mar. Res. 34, 671-696.

Fraga, F., 1981, Upwelling off the Galician Coast, Northwest Spain. In: Coastal Upwelling Series, vol. 1, F.A. Richards, editor, AGU, Washington D.C., pp. 176-182.

Fraga, F., Pérez, F.F., 1990. Transformaciones entre composición química del fitoplancton, composición elemental y relación de Redfield. Scient. Mar. 54, 69-76.

Fraga, F., Pérez, F.F., Figueiras, F.G., Ríos, A.F., 1992, Stoichiometric variations of N, P, C, and $\mathrm{O}_{2}$ during a Gymnodinium catenatum red tide and their interpretation. Mar. Ecol. Prog. Ser. 87, 123-134.

Fraga, F., Ríos, A.F., Pérez, F.F., Figueiras, F.G., 1998. Theoretical limits of oxygen:carbon and oxygen:nitrogen ratios during photosynthesis and mineralisation of organic matter in the sea. Sci. Mar. 62, 161-168.

Friederich, G.E., Codispoti, L.A., 1979. On some factors influencing dissolved silica distribution over the northwest African shelf. J. Mar. Res. 37, 337-353. 
Garber, J.H., 1984. Laboratory study of nitrogen and phosphorus remineralization during the decomposition of coastal plankton and seston. Estuar. Coastal shelf Sci. 18, 685-702.

Haapala, J., 1994. Upwelling and its Influence on nutrient concentration in the coastal area of the Hanko Peninsula, entrance of the Gulf of Finland. Estuar. Coastal Shelf Sci. 38, 507-521.

Harrison, W.G., 1980. Nutrient regeneration and primary production in the sea. In: Falkowski, P.G. (Ed.), Primary Productivity in the Sea, Plenum Press, New York, pp. 433-460.

Howarth, R.W., 1988. Nutrient Limitation of net Primary Production in marine ecosystems. Ann. Rev. Ecol. 19, 89-100.

Huntsman, S.A., Barber, R.T., 1977. Primary production off northwest Africa: the relationship to wind and nutrient conditions. Deep-Sea Res. 24, 25-33.

Jones, P.G.W., 1971. The Southern Benguela Current region in February, 1966: Part. I. Chemical observations with particular reference to upwelling. Deep-Sea Res. 18, 193-208.

Kester D.R., 1975. Dissolved gases other than $\mathrm{CO}_{2}$. In: Chemical Oceanography (Second Edition). Riley J.P. and Skirrow (editors)., 1, 497-556.

Laws, E., 1991. Photosynthetic quotients, new production and net community production in the open ocean. Deep-Sea Res. 38, 143-167.

López-Jamar, E., Cal, R.M., González, G., Hanson, R.B., Rey, J., Santiago, G., Tenore, K.R., 1992. Upwelling and outwelling effects on the benthic regime of the continental shelf off Galicia, NW Spain. J. Mar. Res. 50, 465-488.

Matsukawa, Y., Suzuki, T., 1985. Box model analysis of hydrographic behaviour of nitrogen and phosphorus in a eutrophic estuary. J. Oceanogr. Soc. Japan 41 407-426.

Minster, J.-F., Boulahdid, M., 1987. Redfield ratios along isopycnal surfaces-a complementary study. Deep-Sea Res. 34, 1981-2003.

Millard, R.C., Owens, W.B., Fofonoff, N.P., 1990. On the calculations of the Brunt-Väisälä frequency. Deep-Sea Res. 37, 167-181.

Nelson, D.M., Tréguer, P., Brzezinski, M.A., Leynaert, A., Quéguiner, 1995. Production and dissolution of biogenic silica in the ocean: revised global estimates, comparison with 
regional data and relationship to biogenic sedimentation. Global Biogeochemical Cycles 9, 359-372.

Nogueira, E., Pérez F.F., Ríos A.F., 1997. Seasonal patterns and long-term trends in an estuarine upwelling ecosystem (Ría de Vigo, NW Spain). Estuar. Coastal Shelf Sci. 44. 285-300.

Otto, L, 1975. Oceanography of the Ría de Arousa (NW Spain). Konink Meteor Int Med Verlan 96

Pazos, Y., Figueiras F.G., Álvarez-Salgado X.A., Rosón, G., 1995. The control of succession in red tide species in the Ría de Arousa (NW Spain) by upwelling and stability. In: Lassus P, Arzul G, Erad E, Gentien P, Marcaillou C (eds), Harmful Algal Blooms. Lavoisier, Intercept Ltd, p 645-650.

Pérez, F.F., Mouriño, C., Fraga, F., Ríos, A.F, 1993. Displacement of water masses and remineralization rates off the Iberian Peninsula by nutrient anomalies. J. Mar. Res. 51, 869-892.

Prego, R., 1994. Nitrogen interchanges generated by biogeochemical processes in a Galician ría. Mar. Chem. 45, 167-176.

Prego, R., Bao, R., 1997. Upwelling influence on the Galician coast: silicate in shelf water and underlying surface sediments. Cont. Shelf Res. 17, 307-218.

Redfield, A.C., Ketchum, B.H., Richards, F.A., 1963. The influence of organisms on the composition of sea-water. In: The Sea, vol. 2, M.N. Hill, editor, Wiley and Sons, pp. 26-77.

Ríos, A.F., 1992. El fitoplancton de la Ría de Vigo y sus condiciones ambientales. Ph. D. Thesis. University of Santiago de Compostela, 416 pp.

Ríos A.F., Fraga, F, Pérez, F.F., Figueiras, F.G., 1998. Chemical composition of phytoplankton and particulated organic matter in Ria de Vigo (NW Spain). Sci. Mar. 62, 257-271.

Rosón, G., Álvarez-Salgado, X.A., Pérez, F.F., 1997. A non-stationary box-model to determine residual flows in a partially mixed estuary, based on both thermohaline properties. Application to the Ría de Arousa (NW Spain). Estuar. Coastal Shelf Sci. 44, 249-262. 
Rosón, G., Álvarez-Salgado, X.A., Pérez, F.F., 1999. Carbon cycling in a large coastal embayment, affected by wind-driven upwelling: short-time-scale variability and spatial differences. Mar. Ecol. Prog. Ser. 176, 215-230.

Rosón, G., Pérez, F.F., Álvarez-Salgado, X.A., Figueiras, F.G., 1995. Variation of both thermohaline and chemical properties in an estuarine upwelling ecosystem: Ría de Arousa. l. Time Evolution. Estuar. Coastal Shelf Sci. 41, 195-213.

Rowe, G.T., Clifford, C.H., Smith Jr., K.L., Hamilton, P.L., 1975. Benthic nutrient regeneration and its coupling to primary productivity in coastal waters. Nature 255, 215-217.

Rowe, G.T., Clifford, C.H., Smith Jr., K.L., Hamilton, P.L. 1977. Regeneration of nutrients in sediments off Cape Blanc, Spanish Sahara. Deep-Sea Res. 24, 57-64.

Sambrotto, R.N., Savidge, G., Robinson, C., Boyd, P., Takahashi, T., Karl, D.M., Langdon, C., Chipman, D., Marra, J., Codispoti, L., 1993. Elevated consumption of carbon relative to nitrogen in the surface ocean. Nature 363, 248-250.

Smith, S.V., Hollibaugh, J.T., 1997. Annual cycle and interannual variability of ecosystem metabolism in a temperate climate embayment. Ecological Monographs 67, 509-533.

Sockal, R.R., Rolhf, F.J., 1995. Biometry. Freeman and Company (eds), New York, 887pp

Sverdrup, H.U., Johnson, M.W., Fleming, R.H. 1942. The Oceans, their Physics, Chemistry and General Biology. Prentice-Hall, New York, 1087 pp.

Suess, E., 1981. Phosphate regeneration from sediments of the Perú continental margin by dissolution of fish debris. Geochim. Cosmochim. Acta 45, 577-588.

Takahashi, T., Broecker, W.S., Langer, S., 1985. Redfield ratio based on chemical data from isopycnal surfaces. J. Geophys. Res. 90, 6907-6924.

Tenore, K.R., plus 14 authors, 1982. Coastal upwelling in the Rías Baixas, NW Spain. Contrasting the benthic regimes of the Ría de Arousa and Muros. J. Mar. Res. 40, 701-772.

Tenore, K.R. plus 18 authors (1995) Fisheries and Oceanography off Galicia, NW Spain: Mesoscale spatial and temporal changes in physical processes and resultant patterns of biological productivity. J. Geophys. Res., 100, 10943-10966. 
Treguer, P., Le Corre, P., 1979. The ratios of nitrate, phosphate and silicate during uptake and regeneration phases of the Moroccan upwelling regime. Deep-Sea Res. 26, 163-184.

UNESCO (1985) The international system of units (SI) in oceanography. UNESCO Technical Papers on Marine Science 45, 1-124.

Walsh, J.J., 1991. Importance of continental margins in the marine biogeochemical cycling of carbon and nitrogen. Nature 359, 53-55.

Weis, R.F., 1974. Carbon dioxide in water and seawater: the solubility of a non-ideal gas. Mar. Chem. 2, 203-215.

White, K.K., Dugdale, R.C., 1997. Silicate and nitrate uptake in the Monterey Bay upwelling system. Cont. Shelf Res. 17, 455-472.

Wollast, R., 1991. The coastal organic carbon cycle: Fluxes, sources and sinks. In: Mantoura R.F.C., Martin, J.-M., Wollast, R. (Eds.), Ocean margin processes in global change. J Wiley \& Sons, p 365-381.

Wollast, R., 1993. Interactions of carbon and nitrogen cycles in the coastal zone. In: Wollast R., Mackenzie F.T., Chou L. (Eds), Interactions of C, N, P and S Biogeochemical Cycles and Global Change, Berlin, p 195-210.

Woolf D.K., Thorpe S.A. 1991. Bubbles and the air-sea exchange of gases in near-saturation conditions. J. Mar. Res. 49:435-466

Wooster, W.S., Bakun, A., McClain, D.R., 1976. The seasonal upwelling cycle along the eastern boundary of the North Atlantic. J. Mar. Res. 34, 131-141.

Zimmerman, R.C., Kremer, J.N., Dugdale, R.C., 1987. Acceleration of nutrient uptake by phytoplankton in a coastal upwelling ecosystem: a modelling analysis. Limnol. Oceanogr. 32, 359-367. 


\section{Figure captions}

Fig. 1. Chart of the survey area, the Ría de Arousa (NW Spain), indicating the position of the ten sites where seawater samples were collected. The 20 and 50m isobaths are shown. Lines crossing stations $1,8,7$ and 10 are the boundaries of the study box.

Fig. 2. The 2-D box model. The study box is divided in an upper and a lower layer, separated by a level-of-no-motion, which coincides with the pycnocline. $Q_{\mathrm{x} 1}$ and $Q_{\mathrm{x} 8}$ are the surface horizontal convective flows into the study box from the Ulla and Umia estuaries; $Q_{\mathrm{X} 7}$ is the surface horizontal convective flow from the mouth of the Ría de Arousa to shelf surface waters; $Q_{\mathrm{xo1}}$ and $Q_{\mathrm{xos}}$ are the compensating bottom convective flows from the study box into the Ulla and Umia estuaries; $Q_{\mathrm{x} 07}$ is the compensating bottom flow from the shelf into the lower layer of the study box; $Q_{\mathrm{Z}}$ and $Q_{\mathrm{E}}$ and $M$ are the vertical convective, entrainment and turbulent mixing flows from the lower to the upper layer of the study box; $Q_{\mathrm{R}}+P-E$ is the balance of runoff, precipitation and evaporation in the study box and; $F_{\mathrm{Q}}$ the heat exchange flux across the sea surface.

Fig. 3. Time-course of (a) $\Delta C_{\mathrm{TCOR}}, \Delta N_{\mathrm{T}}, \Delta P$ and $\Delta O_{2 \mathrm{COR}}$ in mmol m $\mathrm{m}^{-2} \mathrm{~d}^{-1}$ of oxygen and (b) $\triangle P O C, \triangle P O N, \triangle P O P$ and $\triangle C h l a$ in $\mathrm{mmol} \mathrm{m}^{-2} \mathrm{~d}^{-1}$ of carbon. The linear equations in Table 3 were used to convert inorganic carbon, nitrogen and phosphorus data into $\mathrm{O}_{2}$ units and organic nitrogen phosphorus and Chla data into carbon units. The solid lines represent the average oxygen $(<N E P>)$ and organic carbon production $(<P O C>)$ obtained from the independent budgets of $\mathrm{C}_{\mathrm{T}}, \mathrm{N}_{\mathrm{T}}, \mathrm{P}$ and $\mathrm{O}_{2}$ and POC, PON, POP and Chla, respectively.

Fig. 4. Short-time-scale (3-4 days) average net production of particulate organic matter versus average net ecosystem production in the study box . Units, mmol m $\mathrm{m}^{-2} \mathrm{~d}^{-1}$ of carbon.

Fig. 5. Time-course of (a) Ekman transport, $I_{\mathrm{W}}$; (b) heat-exchange flux across the sea surface, $F_{\mathrm{Q}}$; (c) average depth-integrated Brunt-Väisälä frequency, $B V$; and (d) average $(<N E P>)$ and modelled net ecosystem production. $B V=\sqrt{\frac{g}{Z / 2}} \cdot \ln \frac{\rho_{L}}{\rho_{U}}$, where $g$ is the gravity 
acceleration, $Z$ is the average depth of the study volume in the Ría de Arousa (23 m) and $\rho_{\mathrm{L}}$ and $\rho_{\mathrm{U}}$ the density of the lower and upper layers, respectively (Millard et al. 1990).

Fig. 6. Average (a) residual flows; (b) inorganic salts and oxygen fluxes; and (c) particulate organic matter fluxes during the upwelling season (June 8 to October 13, 1989). $Q_{\mathrm{X}}, Q_{\mathrm{xo}}$, $Q_{\mathrm{Z}}, Q_{\mathrm{E}}, M_{\mathrm{Z}}$ and $Q_{\mathrm{R}}+P-E$ in $\mathrm{m}^{3} \mathrm{~s}^{-1}$. Nutrient and organic mater fluxes in mol s $\mathrm{s}^{-1}$.

Fig.7. Average (a) residual flows; (b) inorganic salts and oxygen fluxes; and (c) particulate organic matter fluxes during the autumn downwelling (October 13 to 30, 1989). $Q_{\mathrm{x}}, Q_{\mathrm{xo}}$, $Q_{\mathrm{Z}}, Q_{\mathrm{E}}, M_{\mathrm{Z}}$ and $Q_{\mathrm{R}}+P-E$ in $\mathrm{m}^{3} \mathrm{~s}^{-1}$. Nutrient and organic mater fluxes in $\mathrm{mol} \mathrm{s} \mathrm{s}^{-1}$. 
Stoichiometry of the net ecosystem metabolism in a coastal inlet affected by upwelling. The Ría de Arousa (NW Spain)

Fíz F. Pérez $^{\mathrm{a}, *}$, X.A. Álvarez-Salgado ${ }^{\mathrm{a}}$ and Gabriel Rosón ${ }^{\mathrm{b}}$

${ }^{\mathrm{a}}$ Instituto de Investigacións Mariñas, C.S.I.C. Eduardo Cabello 6, Vigo 36208, Spain

${ }^{\mathrm{b}}$ Facultad Ciencias del Mar, Universidad de Vigo, Apartado 874, Vigo 36200, Spain

Submitted to: Marine Chemistry

*Corresponding author. Email: fiz@iim.csic.es 
Abstract. The net uptake of inorganic carbon and nitrogen, phosphate and silicate and the net production of dissolved oxygen and organic carbon, nitrogen and phosphorus have been examined in the Ría de Arousa, a large coastal embayment in the NW Iberian upwelling system. Fluxes and net budgets were estimated with a non-stationary 2-D box model (Rosón et al., 1997) and the distributions of the different species acquired twice a week between May and October 1989 (Rosón et al., 1995). High N/P and N/Si net uptake ratios of 21 and 3.2 were observed during the upwelling season. The rapid recycling of phosphorus compared to nitrogen and the recurrent succession from pioneer diatoms $(\mathrm{Si} / \mathrm{N} \sim 1)$ to red-tide forming species $(\mathrm{Si} / \mathrm{N}=0)$ following the periodic upwelling pulses are the reasons behind the observed ratios. The molar ratios of dissolved oxygen production to inorganic carbon $(-1.48)$ and nitrogen uptake (-10.2) during the upwelling season agree with the Redfield stoichiometry. On the contrary, net nutrient regeneration occurred with $\mathrm{N} / \mathrm{P}, \mathrm{N} / \mathrm{Si}$ and $\mathrm{O}_{2} / \mathrm{C}$ ratios of $7.4,1.0$ and -1.02 during an intense autumn downwelling event. These low ratios are due to the release of an excess of phosphate, silicate and $\mathrm{CO}_{2}$ from the sediments. Conversely, the production of inorganic nitrogen is associated to the consumption of dissolved oxygen following a Redfield ratio of -10.0 . Whereas the $\mathrm{C} / \mathrm{N}$ ratio of the suspended organic matter produced during the upwelling season and consumed during the autumn downwelling event is 6.3-6.7, the N/P ratio changes from 11 during the upwelling season to 15 during the autumn downwelling. About 1/5 of the dissolved oxygen produced during the upwelling season and consumed during the autumn downwelling is delivered to and came from the atmosphere, respectively. Despite the $\mathrm{C} / \mathrm{N} / \mathrm{P} / \mathrm{O}_{2}$ ratios differ from the Redfield values, the high correlation between nutrient salts consumption and dissolved oxygen production $\left(r^{2}=0.74-0.86\right)$ allow to estimate an average net ecosystem production (NEP) from the individual elements. The 3-4 d time-scale variability of the average NEP depends on the two week periodicity of upwelling pulses, the heat exchange across the sea surface and the stability of the water column. As much as $70 \%$ of the total variability can be explained with a linear combination of these parameters. 
Keywords: Nutrients, $\mathrm{CO}_{2}$, net ecosystem production, upwelling, downwelling, Rías Baixas

(NW Iberian upwelling system)

\section{Glossary of terms}

$C_{\mathrm{i}}$

$C_{\mathrm{L}}, C_{\mathrm{U}}$

$C_{\mathrm{R}}$

$C_{\mathrm{T}}$

$D$

$F_{\mathrm{CO} 2}, F_{\mathrm{O} 2}, F_{\mathrm{Q}}$

$F_{\mathrm{E}}$

$F_{\mathrm{Qi}}$

$F_{\mathrm{R}}$

$i-o$

$I-O$

$I_{W}$

$K_{\mathrm{CO} 2}, K_{\mathrm{O} 2}$

$\mathrm{M}_{\mathrm{Z}}$

$B V$

NEP

$<N E P>$

$N_{\mathrm{T}}$

$<P O C>$

$Q_{\mathrm{X}}, Q_{\mathrm{X} 0}, Q_{\mathrm{Z}}$

$Q_{\mathrm{E}}$

$Q_{\mathrm{R}}, P, E$

$R_{\mathrm{C}}, R_{\mathrm{N}}, R_{\mathrm{P}}$

$\Delta$ Chl a

$\Delta C_{\mathrm{TCOR}}$

$\triangle \mathrm{CaCO}_{3}$

$\Delta N_{\mathrm{T}}$

$\Delta O_{2 \mathrm{COR}}$

$\Delta P$

$\Delta S i$

$\triangle P O C, \triangle P O N, \triangle P O P$

$\triangle T A$
Concentration of any species in a convective flow $\left(Q_{\mathrm{x}}, Q_{\mathrm{x} 0}, Q_{\mathrm{z}}\right)$

Concentration of any species in the lower and upper layer of the Ría

Concentration of any species in the river flow $\left(Q_{R}\right)$

Total inorganic carbon concentration

Flux of any species carried by the turbulent diffusion flow $\left(M_{\mathrm{Z}}\right)$

$\mathrm{CO}_{2}, \mathrm{O}_{2}$ and heat fluxes across the sea surface

Flux of any species associated to the 'boundary movement' $\left(Q_{E}\right)$

Flux of any species carried by a convective flow $\left(Q_{\mathrm{X}}, Q_{\mathrm{x} 0}, \mathrm{Q}_{\mathrm{z}}\right)$

Flux of any species carried by the river flow $(R)$

Net daily budget of inputs minus outputs in a box for any species

Average $i$ - $o$ between two consecutive surveys

Upwelling index

Piston velocities for $\mathrm{O}_{2}$ and $\mathrm{CO}_{2}$

Turbulent diffusion flow

Average depth-integrated Brunt-Väisälä frequency

Net ecosystem production, primary production minus community respiration

Average NEP from $\Delta \mathrm{C}_{\mathrm{TCOR}}, \Delta N_{\mathrm{T}}, \Delta \mathrm{P}$ and $\Delta \mathrm{O}_{\mathrm{T} 2 \mathrm{COR}}$

Total inorganic nitrogen (nitrate + nitrite + ammonia) concentration

Average particulate organic matter production from $\triangle P O C, \triangle P O N$ and $\triangle P O P$

Horizontal (upper and lower) and vertical convective flows

Net upward movement of the boundary between upper and lower layer

River flow, precipitation and evaporation rates

$\mathrm{O}_{2}$ production to $\mathrm{C}_{\mathrm{T}}, \mathrm{N}_{\mathrm{T}}$ and $\mathrm{P}$ consumption ratios

Net chlorophyll a production

$\mathrm{CaCO}_{3}$ corrected net $\mathrm{C}_{\mathrm{T}}$ production

Net calcium carbonate fixation

Net $N_{\text {T }}$ production

Ammonia and nitrite corrected net oxygen production

Net phosphate production

Net silicate production

Net particulate organic carbon, nitrogen and phosphorus production

Net total alkalinity production 


\section{Introduction}

The synthesis of the organic tissues of marine phytoplankton in the photic layer of the World Ocean is deeply associated with the consumption of nutrient salts and the production of dissolved oxygen (Redfield et al., 1963). The pioneer $-\mathrm{O}_{2} / \mathrm{C} / \mathrm{N} / \mathrm{P}$ Redfield numbers of 138/106/16/1 have been recently revisited (Anderson, 1995; Fraga et al., 1998), after revision of the biogeochemical composition of marine phytoplankton (Fraga and Pérez, 1990; Laws, 1991). $\mathrm{O}_{2} / \mathrm{CO}_{2} /$ nutrients data have been used to infer the composition of the phytogenic material by examining the resultant stoichiometric ratios during its aerobic oxidation at depth (Takahashi et al., 1985; Minster and Boulahdid, 1987; Anderson and Sarmiento, 1994). However, the stoichiometric ratios obtained from the phytoplankton biochemical composition and from the $\mathrm{O}_{2} / \mathrm{CO}_{2} /$ nutrients data in the upper ocean are not equivalent but complementary. The differences will depend on the relative importance of recycling processes (Sambrotto et al., 1993).

The ratios of nutrient consumption and organic matter production in a given zone are determined by: 1) the actual phytoplankton biochemical composition, which results from the production of primary metabolites in some proportions (Fraga and Pérez, 1990; Laws, 1991; Anderson, 1995, Fraga et al. 1998); and 2) the subsequent utilisation by a particular community of organisms. The disparity between consumption and production intensifies in coastal upwelling regions due to enhanced primary and secondary production rates and acute pelagic and benthic mineralization processes (Rowe et al., 1975; Walsh, 1991; Wollast, 1991; 1993; Christensen, 1994).

The western coast of the Iberian Peninsula experiences upwelling favourable winds during the spring and summer (Wooster et al., 1976; Blanton et al., 1987). In addition to the upwelling of Eastern North Atlantic Central Water (ENACW), the nutrient condition of shelf waters is affected by the organic matter outwelled from the 'Rías Baixas', four large V-shaped coastal indentations (Fraga, 1981; Tenore et al., 1982; 1995; Álvarez-Salgado 1993; 1997). Coastal upwelling forces a 2-D circulation pattern along the main axis of the rías (Otto, 1975). 
The circulation is positive during upwelling events and reversed during the subsequent upwelling relaxations, or under downwelling conditions (Rosón et al., 1997). Nutrients transported by upwelled ENACW into the rías are consumed there at high rates, and part of the produced organic matter is exported to the adjacent shelf (Prego 1994; Rosón et al., 1995; Álvarez-Salgado, 1996a; Doval et al. 1997). As a consequence, extensive accumulation of organic matter (López-Jamar et al., 1992) and opal (Prego and Bao, 1997) occurs in pelagic sediments off the rías.

An intensive research programme was conducted in the Ría de Arousa (NW Spain) and the adjacent shelf from May to October 1989 to quantify the short-time-scale variability on the fluxes of some selected biogeochemical species. The qualitative studies of AlvarezSalgado et al. (1993) and Rosón et al. (1995) demonstrated the key contribution of wind-driven upwelling/downwelling events to the observed distributions of physical and biogeochemical variables either in the Ría and the shelf. The short-time-scale hydrographic variability imposed by the periodic ( $\sim 2$ wk) succession of upwelling/downwelling events precludes the application of the stationary box-model approach to calculate water flows. Therefore, Rosón et al. (1997) developed a 2-D non-stationary mass-heat weighted box-model to calculate water flows in the Ría de Arousa. The calculated flows were positively correlated $(r=+0.67)$ with the Ekman transport, showing enhanced positive circulation during upwelling and reversed circulation during upwelling relaxation and downwelling. Knowledge of water flows allowed Álvarez-Salgado et al. (1996a, 1996b) and Rosón et al. (1999) to set the spatial and short-time-scale variability in the fluxes and net budgets of nitrogen and carbon species. They observed that the net ecosystem production (NEP) of carbon and nitrogen were linked to the Ekman transport, with maximum values after strong upwelling events supported by external nitrate and minimum values after periods of prolonged relaxation, when ammonium accumulated in the Ría. The culture of mussels on hanging ropes - the most intensive over world (Tenore et al. 1982) — had a major impact on carbon and nitrogen biogeochemistry, enhancing the formation of dissolved organic matter. During the 
upwelling season, total inorganic carbon trapped in the Ría (average, $0.95 \mathrm{~g} \mathrm{C} \mathrm{m}^{-2} \mathrm{~d}^{-1}$ ) was distributed between organic (88\%, NEP) and inorganic $\left(12 \%, \mathrm{CaCO}_{3}\right)$ forms. The NEP was mainly exported to the shelf as particulate (25\%) and dissolved (58\%) organic carbon. Carbon and nitrogen biogeochemistry was deeply affected by the strong autumn downwelling event of late October 1989. Net regeneration was dominant all over the Ría (average $-0.66 \mathrm{~g} \mathrm{C} \mathrm{m}^{-2} \mathrm{~d}^{-1}$ ), with an intense release of $\mathrm{CO}_{3} \mathrm{H}^{-}$and $\mathrm{NH}_{4}{ }^{+}$from the sediments (average $0.53 \mathrm{~g} \mathrm{C} \mathrm{m}^{-2} \mathrm{~d}^{-1}$ and $0.10 \mathrm{~g} \mathrm{~N} \mathrm{~m}^{-2} \mathrm{~d}^{-1}$, respectively).

Once the carbon and nitrogen biogeochemistry of the Ría de Arousa during the upwelling season 1989 have been studied in detail, we plan to extend our 2-D non-stationary box-model approach to calculate the NEP of phosphorus, silicon and dissolved oxygen in the present complementary work. Our main objectives here are two. 1) to study the $\mathrm{O}_{2} / \mathrm{C} / \mathrm{N} / \mathrm{P} / \mathrm{Si}$ stoichiometry of the NEP in the Ría de Arousa: how the hydrography affects the deviations from the Redfield ratios?. And 2) to predict the $\mathrm{O}_{2} / \mathrm{C} / \mathrm{N} / \mathrm{P}$ average NEP rates in the Ría de Arousa from the external physical forces acting on the system: could the NEP of a coastal inlet affected by wind-driven upwelling be parametrised using only physical and meteorological variables?

\section{Material and methods}

\subsection{Sampling programme}

Data used in this work were collected from 5 to 7 depths at 10 fixed stations distributed all over the Ría de Arousa (Fig. 1). This programme was repeated 46 times from 12 May to 30 October 1989, which means a survey every 3-4 days. The surface area and volume bounded by stns $1,7,8$ and 10 are $182.4 \mathrm{Km}^{2}$ and $4.203 \mathrm{Km}^{3}$. The remaining $48.5 \mathrm{Km}^{2}$ and $0.060 \mathrm{Km}^{3}$ comprise the innermost part of the ría: the estuaries of the rivers Ulla and Umia. Salinity, dissolved oxygen, 5-nutrients, $\mathrm{pH}$, total alkalinity (TA), chlorophyll and particulate organic matter (carbon, nitrogen and phosphorous) were determined by the methods described in Rosón et al. (1995) and Álvarez-Salgado et al. (1996a). Total inorganic carbon $\left(\mathrm{C}_{\mathrm{T}}\right)$ and 
partial pressure of $\mathrm{CO}_{2}$ at the sea surface $\left(\mathrm{pCO}_{2}\right)$ were calculated from $\mathrm{pH}$ and TA with the equations of the thermodynamic equilibrium of the $\mathrm{CO}_{2}$ system. In addition, daily data of wind over the shelf, river flows $\left(Q_{R}\right)$, and precipitation rates $(P)$ were obtained from the Meteorological observatory at Cape Finisterre, the gauge stations at the rivers Ulla and Umia and the meteorological observatory at Vilagarcía de Arousa, respectively.

\subsection{Variables derived from collected data}

The Ekman transport $\left(I_{\mathrm{W}}\right.$, in $\left.\mathrm{m}^{2} \mathrm{~s}^{-1}\right)$ was calculated from Cape Finisterre wind data following the method of Bakun (1973). The evaporation (E) was obtained with the empirical formulae of Otto (1975) for the Ría de Arousa. The heat exchange flux across the sea surface $\left(F_{\mathrm{Q}}\right)$ was evaluated with the Mosby's formulae (Sverdrup et al., 1942), considering the cloudiness, the back radiation and the evaporation rates (Rosón et al., 1997).

Carbon and dissolved oxygen budgets must include $\mathrm{CO}_{2}$ and $\mathrm{O}_{2}$ exchange with the atmosphere. Following Woolf and Thorpe (1991), $\mathrm{CO}_{2}$ fluxes across the sea surface $\left(\mathrm{FCO}_{2}\right.$, in mol s${ }^{-1}$ ) were calculated by Rosón et al. (1999) using the equation:

$$
F_{\mathrm{CO}_{2}}=k_{\mathrm{CO}_{2}} \cdot S_{\mathrm{CO}_{2}} \cdot\left(p C \mathrm{O}_{2}-p \mathrm{CO}_{2 \mathrm{ATM}}\right) \cdot \mathrm{A}
$$

where $k \mathrm{CO}_{2}\left(\mathrm{~m} \mathrm{~s}^{-1}\right)$ is the piston velocity, $\mathrm{SCO}_{2}\left(\mathrm{~mol} \mathrm{l}^{-1} \mathrm{~atm}{ }^{-1}\right)$ is the solubility of $\mathrm{CO}_{2}$ in seawater (Weiss 1974), and $A$ is the surface area of the Ría de Arousa. Accordingly, oxygen fluxes $\left(\mathrm{FO}_{2}\right.$, mol s$\left.{ }^{-1}\right)$ were calculated in the present work with the following equation:

$$
F_{O_{2}}=k_{O_{2}} \cdot\left(O_{2 S A T}-O_{2}\right) \cdot A
$$

where $\mathrm{KO}_{2}\left(\mathrm{~m} \mathrm{~s}^{-1}\right)$ is the piston velocity for oxygen, calculated from local wind speed following Kester (1975) and $\mathrm{O}_{2 \mathrm{SAT}}$ is the oxygen concentration at saturation (UNESCO, 1985).

\subsection{Calculation of water flows and species fluxes with the 2-D box model}

Water flows were taken from Rosón et al. (1997). These authors estimated the upper $\left(Q_{\mathrm{X}}\right)$ and lower $\left(Q_{\mathrm{x} 0}\right)$ horizontal convective flows, the vertical convective $\left(Q_{\mathrm{Z}}\right)$ and diffusive $\left(M_{\mathrm{Z}}\right)$ flows and 'boundary movement' $\left(Q_{\mathrm{E}}=d V / d t\right)$ in the Ría de Arousa from May to October 
1989 with a 2-D non-stationary salt-heat weighted box model (Fig. 2). $Q_{\mathrm{E}}$ is due to time-changes in the layer volumes (V), associated to the net vertical displacement of the boundary between the upper and lower. The inputs to the model are: 1) the profiles of salinity and temperature at the 10 sampling sites; 2) $Q_{\mathrm{R}}+P-E$ and $F_{\mathrm{Q}}$; and 3) the geometry of the Ría (surface and cross areas, volumes), obtained from accurate charts published by the Spanish 'Instituto Geográfico de la Marina’.

Knowledge of water flows and average concentrations of the different species of every study element in the upper and lower volumes and cross areas considered (Table 1), allow us to obtain species fluxes and net budgets. The flux of any chemical species $\left(F_{\mathrm{Qi}}\right)$ transported by a convective water flow $\left(Q_{\mathrm{i}}\right)$ is the product of flow times concentration $\left(C_{\mathrm{i}}\right): F_{\mathrm{Qi}}=Q_{\mathrm{i}} \cdot C_{\mathrm{i}}$. The river flux is $F_{\mathrm{R}}=Q_{\mathrm{R}} \cdot C_{\mathrm{R}}$, with $C_{\mathrm{R}}$ the concentration in the river flow. The vertical diffusive flux is $D=M_{\mathrm{Z}} \cdot\left(C_{\mathrm{L}}-C_{\mathrm{U}}\right)$, being $C_{\mathrm{L}}$ and $C_{\mathrm{U}}$ the concentrations in the upper and lower layer, respectively. The 'boundary movement' flux is $F_{\mathrm{E}}=C \cdot d V / d t$. Finally, $F_{\mathrm{ATM}}$ is the $\mathrm{CO}_{2}$ or $\mathrm{O}_{2}$ air-sea exchange flux, taken from Rosón et al. (1999) and calculated from eq (2) respectively. Concentrations are in $\mathrm{mol} \mathrm{m}^{-3}$, water flows in $\mathrm{m}^{3} \mathrm{~s}^{-1}$ and species fluxes in $\mathrm{mol} \mathrm{s} \mathrm{s}^{-1}$.

The budget of inputs and outputs (i-o, in $\left.\mathrm{mol} \mathrm{s}^{-1}\right)$ of any species in the Ría results from accumulation, $\partial(C \cdot V) / \partial t$, and biogeochemical processes, $\delta C$ (positive, production; negative, consumption). Therefore:

$$
\begin{aligned}
& i-o=Q_{\mathrm{R}} \cdot C_{\mathrm{R}}+Q_{\mathrm{XO} 7} \cdot C_{\mathrm{O} 7}+Q_{\mathrm{X} 1} \cdot C_{1}+Q_{\mathrm{X} 8} \cdot C_{8}-Q_{\mathrm{X} 7} \cdot C_{7}-Q_{\mathrm{XO} 1} \cdot C_{\mathrm{O} 1}-Q_{\mathrm{XO} 8} \cdot C_{\mathrm{O} 8}-F_{\mathrm{ATM}} \\
& \delta C=\frac{\partial(C \cdot V)}{\partial t}-(i-o)
\end{aligned}
$$

The average $\delta C$ between surveys $\mathrm{j}-1$ and $\mathrm{j}\left(\Delta C\right.$, in $\left.\mathrm{mol} \mathrm{s}^{-1}\right)$ can be obtained by integrating Eq. (4): 


$$
\Delta C=\frac{\int_{t_{j-1}}^{t_{j}} \delta C d t}{t_{j}-t_{j-1}}=V \cdot \frac{C_{t}-C_{t-1}}{t_{t}-t_{t-1}}-\frac{\int_{t_{j-1}}^{t_{j}}(i-o) \cdot d t}{t_{t}-t_{t-1}}
$$

Average $i-o$ between surveys $\mathrm{j}-1$ and $\mathrm{j}$ was calculated assuming linear changes from $t_{\mathrm{j}-1}$ to $t_{\mathrm{j}}$ of 1) salinity, temperature, $Q_{\mathrm{R}}+P-E, F_{\mathrm{Q}}$ and $V$, for calculating water flows and 2) $C, C_{\mathrm{i}}$ and $C_{\mathrm{R}}$ for calculating fluxes. Finally, values of $\Delta C$ in mol s${ }^{-1}$ are converted to $\mathrm{mmol} \mathrm{m}^{-2} \mathrm{~d}^{-1}$ multiplying by the factor 0.474 , which considers the surface area of the Ría de Arousa (182.4 $\left.\mathrm{Km}^{2}\right)$. The budget of any species in the upper layer would require to consider the river flux $\left(F_{\mathrm{R}}\right)$ the inward and outward horizontal convective fluxes $\left(F_{\mathrm{Qx} 1}, F_{\mathrm{Qx} 8}, F_{\mathrm{Qx} 7}\right)$, the three vertical fluxes ( $F_{\mathrm{Qz}}, F_{\mathrm{E}}$ and $D$ ) and $F_{\mathrm{ATM}}$. The budget for the lower layer can be obtained by subtracting the budget of the upper layer form the budget of the box.

Fluxes and net budgets of nitrogen and carbon species were taken from Álvarez-Salgado et al. (1996a) and Rosón et al. (1999) respectively, who described the method above in more detail. Oxygen, phosphorus, silicon and chlorophyll fluxes and budgets were calculated for the present work.

\subsection{Error in the calculation of species fluxes and budgets}

Rosón et al. (1997) reported average \pm std errors of $0.002 \pm 0.029$ pss and $0.012 \pm 0.387^{\circ} \mathrm{C}$ produced by the 2-D non-stationary box model on the salinity and temperature budgets respectively. These errors represent a $<1 \%$ error on water fluxes when compared with the average vertical gradients of salinity $(0.234 \mathrm{pss})$ and temperature $\left(1.7^{\circ} \mathrm{C}\right)$. However the standard deviation of errors represents $10-20 \%$ of the average gradient, producing the corresponding errors in the water flows. The time course of the thermohaline and chemical fields are strongly coupled (Table 1) in response to the succession of upwelling/downwelling events (AlvarezSalgado et al. 1993, Rosón et al. 1995). Therefore, it must be expected that the average error in species budgets are similar to the average errors in salinity and temperature. 
It is possible also to derive the error in water and species fluxes and budgets associated to the precision on the determination of the variables contributing to the calculation of fluxes and budgets. Since the density gradients in the Ría de Arousa during the study period are mainly (85\%) controlled by temperature, the error of the 2-D box model during the estimation of $Q_{\mathrm{X}}$ $\left(\varepsilon_{q}\right)$ can be determined as:

$\varepsilon_{q}=\frac{\varepsilon_{R} \cdot\left(\bar{T}_{I}-T_{R}\right)+\varepsilon_{D}+\varepsilon_{H}+2 \cdot \varepsilon_{T} \cdot\left(\left|Q_{X}\right|+Q_{R}\right)}{\bar{T}_{I}-\bar{T}_{O}}$

where $\varepsilon_{R}$ is the error in the river flows $\left( \pm 0.5 \mathrm{~m}^{3} \mathrm{~s}^{-1}\right), T_{R}$ is the average river temperature, $\varepsilon_{D}$ is the error in the estimation of the heat exchange across the sea surface $\left( \pm 3 \cdot 10^{9} \mathrm{cal} \mathrm{s}^{-1}\right), \varepsilon_{D}$ is the error in the estimation of the heat content change of the Ría de Arousa $\left(V \cdot 2 \varepsilon_{T} /\left(t_{j}-t_{j-1}\right)=\left(4.2 \cdot 10^{9} \cdot 0.02 / 3.5 \cdot 86400\right)= \pm 278{ }^{\circ} \mathrm{C} \mathrm{m}^{3} \mathrm{~s}^{-1}\right)$ and $\varepsilon_{T}$ is the error of temperature measurements $\left(0.01^{\circ} \mathrm{C}\right)$. The average $Q_{\mathrm{x}}, Q_{\mathrm{R}}$ and the vertical gradient of temperature are $3300 \mathrm{~m}^{3} \cdot \mathrm{s}^{-1}, 27 \mathrm{~m}^{3} \cdot \mathrm{s}^{-1}$ and $1.7^{\circ} \mathrm{C}$, respectively. So, the average $\varepsilon_{q}$ is $\pm 210 \mathrm{~m}^{3} \cdot \mathrm{s}^{-1}$, equivalent to $6 \%$ of $Q_{\mathrm{X}}$.

Considering the conservation of volume $\left(Q_{\mathrm{X}}=Q_{\mathrm{XO}}+R\right)$ and the very low contribution of continental runoff to the error calculation of species budgets, equation (3) can be simplified as:

$i-o=Q_{\mathrm{XO} 7} \cdot\left(C_{\mathrm{O} 7}-C_{7}\right)-Q_{\mathrm{XO} 1} \cdot\left(C_{\mathrm{O} 1}-C_{1}\right)-Q_{\mathrm{XO} 8} \cdot\left(C_{\mathrm{O} 8}-C_{8}\right)-F_{\mathrm{ATM}}$

After replacement of eq. (3) by eq. (7) in eq. (4) and (5) the resulting error of any species budget $\left(\varepsilon_{\Delta C}\right)$ is:

$$
\varepsilon_{\Delta C}=V \cdot \frac{2 \varepsilon_{C}}{\left(t_{j}-t_{j-1}\right)}+2 \varepsilon_{C} \sum_{i=1,7,8} Q_{i}+\overline{(C o-C)} \cdot \sum_{i=1,7,8} \varepsilon_{q}+\varepsilon_{F a t m}
$$

where $\varepsilon_{C}$ is the analytical error of the species (Table 2), $\varepsilon_{\text {Fatm }}$ is the error of flux exchange for $\mathrm{CO}_{2}\left( \pm 0.2 \mathrm{~mol} \mathrm{~s}^{-1}\right)$ and $\mathrm{O}_{2}\left( \pm 1 \mathrm{~mol} \mathrm{~s}^{-1}\right)$, and $\overline{\mathrm{Co}-\mathrm{C}}$ is the average vertical gradient in the volume bounded by stns $1,8,7$ and 10 (Table 1). The average estimated error for the 
upwelling season and the autumn downwelling are shown in Table 2. These errors for $\mathrm{O}_{2}, \mathrm{~N}_{T}$, phosphate and silicate are $20-30 \%$ of $\Delta \mathrm{C}$ for both the upwelling and downwelling periods. The estimated average error for $\Delta C_{\mathrm{T}}$ is about $60-70 \%$, due to the high $\varepsilon_{\mathrm{C}} /\left(C_{\mathrm{O}}-C\right)$ ratio for $\mathrm{C}_{\mathrm{T}}$ compared with the other species. However, these large error estimations are in contradiction with the high correlations of $\Delta C_{\mathrm{T}}$ with $\Delta \mathrm{O}_{2}$ and $\Delta N_{\mathrm{T}}$ (Table 3) suggesting that the proper error of $\Delta \mathrm{C}$ for any species have to be much lower than the errors estimated in Table 2. A similar reasoning can be applied to the particulate organic matter budgets. Following Matsukawa and Suzuki (1985) 'this is probably because the terms and properties involved in the calculations are so many that the averaging effect acting on the independent errors become large enough to decrease the real errors considerably'. So, the real contribution of the analytical error is probably much lower than expected from eq. (8).

\section{Result}

\subsection{Coupling between $\mathrm{O}_{2}, C, N, P$ and Si species net production rates}

The net consumption of total inorganic carbon $\left(\Delta C_{\mathrm{T}}\right)$, total inorganic nitrogen $\left(\Delta N_{\mathrm{T}}\right)$ and phosphate $(\Delta P)$ is compared with the net production of oxygen $\left(\Delta \mathrm{O}_{2}\right)$, obtained solving eq. (5) for the chemical species considered (Table 3). $\Delta C_{\mathrm{T}}$ (Rosón et al., 1999) and $\Delta \mathrm{O}_{2}$ have to be corrected previously. The contribution of calcium carbonate fixation $\left(\triangle \mathrm{CaCO}_{3}\right)$, not related to $\mathrm{O}_{2}$ production, have to be subtracted from $\Delta C_{\mathrm{T}}$. For deep ocean waters $\Delta \mathrm{CaCO}_{3}=$ $-1 / 2 \cdot\left(\Delta \mathrm{TA}+\Delta \mathrm{NO}_{3}{ }^{-}\right)$(Broecker and Peng, 1982; Takahashi et al., 1985). However, for coastal and estuarine waters the contribution of nitrite and ammonium have to be considered as well (Fraga et al., 1992):

$$
\Delta C_{\mathrm{TCOR}}=\Delta C_{\mathrm{T}}+\Delta \mathrm{CaCO}_{3}=\Delta C_{\mathrm{T}}-1 / 2 \cdot\left(\Delta \mathrm{TA}+\Delta N \mathrm{NO}_{3}{ }^{-}+0.45 \cdot \Delta N \mathrm{NO}_{2}^{-}-\Delta N H_{4}{ }^{+}\right)
$$

The amount of $\mathrm{O}_{2}$ produced during the synthesis of phytogenic organic matter depend on the inorganic nitrogen source (nitrate, nitrite or ammonium). The synthesis from nitrate produce 0.5 and 2 moles of $\mathrm{O}_{2}$ per mol of $\mathrm{N}$ consumed more than from nitrite and ammonium, 
respectively. Therefore, in order to compare $\Delta N_{\mathrm{T}}$ with $\Delta \mathrm{O}_{2}$, it is necessary to refer $\Delta \mathrm{O}_{2}$ to an unique nitrogen source (Smith and Hollibaugh, 1997). We have used nitrate as reference to compare with the stoichiometric ratio $R_{\mathrm{N}}\left(=-\Delta \mathrm{O}_{2} / \Delta N \mathrm{O}_{3}^{-}\right)$for deep ocean waters (Minster and Buholahdid, 1987). Following Fraga et al. (1992):

$\Delta O_{2 \mathrm{COR}}=\Delta \mathrm{O}_{2}-0.5 \cdot \Delta N \mathrm{O}_{2}^{-}-2 \cdot \Delta N H_{4}^{+}$

Since $\Delta P$ and $\Delta C_{\mathrm{TCOR}}$ are associated to the net consumption of the three nitrogen forms, it is necessary to use $\Delta O_{2 \mathrm{COR}}$ to compare with the corresponding stoichiometric ratios $R_{\mathrm{P}}$ $\left(=-\Delta O_{2} / \Delta P\right)$ and $R_{\mathrm{C}}\left(=-\Delta O_{2} / \Delta C_{\mathrm{T}}\right)$. The recently revised $-\mathrm{O}_{2} / \mathrm{C} / \mathrm{N} / \mathrm{P}$ Redfield ratios are 149/106/16/1 (Anderson, 1995; Fraga et al., 1998), yielding a reference values of $R_{\mathrm{C}}, R_{\mathrm{N}}$ and $R_{\mathrm{P}}$ of $1.41,9.31$ and 149 respectively.

The direct correlation of $\Delta C_{\mathrm{TCOR}}, \Delta N_{\mathrm{T}}$, and $\Delta P$ with $\Delta O_{2 \mathrm{COR}}$ is $r^{2}=0.74-0.86$ (model II; Sockal and Rolhf, 1995), indicating a strong coupling between the consumption of nutrient salts and the production of dissolved oxygen at the short time scale (3-4 days). The calculated slopes (Table 3) are on a par with the stoichiometric ratios $R_{\mathrm{C}}, R_{\mathrm{N}}$ and $R_{\mathrm{P}}$. Whereas our $R_{\mathrm{N}}$ value of $9.7 \pm 0.8$ agrees with the values usually obtained during the mineralization of organic matter in oxic conditions, our $R_{\mathrm{P}}$ of $142 \pm 14$ is in the low end of the wide range reported in the literature (Redfield et al., 1963; Takahashi et al., 1985; Minster and Boulahdid, 1987; Pérez et al., 1993; Anderson and Sarmiento, 1994; Anderson, 1995; Castro et al., 1998). On the other hand, our $R_{\mathrm{C}}$ of $1.05 \pm 0.06$ is rather low compared with the revised Redfield value. Although the y-intercept of the regression between $\Delta O_{2 \mathrm{COR}}$ and $\Delta N_{\mathrm{T}}$ is not significantly different from zero, the corresponding regressions with $\Delta C_{\mathrm{TCOR}}$, and $\Delta P$ indicate a significant $\mathrm{CO}_{2}$ and $\mathrm{HPO}_{4}{ }^{2-}$ production (i.e. mineralization) of 26 and $0.27 \mathrm{mmol} \mathrm{m}^{-2} \mathrm{~d}^{-1}$ at $\Delta O_{2 \mathrm{COR}}=0$. These figures represent $\sim 30 \%$ and $20 \%$ of the total variability in $\Delta C_{\mathrm{TCOR}}$ and $\Delta P$, respectively.

The correlations between $\Delta C_{\mathrm{TCOR}}, \Delta N_{\mathrm{T}}$, and $\Delta P$ are very high as well $\left(r^{2}=0.75-0.85\right)$ with a N/P ratio of $15 \pm 1$ and a C/N ratio of $8.4 \pm 0.8$ — well above the Redfield value of 6.6 , in agreement with the low $R_{\mathrm{C}}$ obtained. On the other hand, the correlation between $\Delta S i$ and $\Delta N_{\mathrm{T}}$, is 
much lower $\left(r^{2}=0.61\right)$, as silicate is only consumed by diatoms. The slope of the correlation gives a $\mathrm{N} / \mathrm{Si}$ ratio of $1.4 \pm 0.2$, higher than the world average $\mathrm{N} / \mathrm{Si} 1 / 1$ ratio of marine diatoms (Nelson et al., 1995). In addition, the y-intercept denote net mineralization of $3.6 \mathrm{mmol} \mathrm{m}^{-2} \mathrm{~d}^{-1}$ of silicate at $\Delta N_{\mathrm{T}}=0$, which represents about $30 \%$ of the total variability of $\Delta S i$.

The net production of suspended organic carbon $(\triangle P O C)$, nitrogen $(\triangle P O N)$, phosphorous $(\triangle P O P)$ and chlorophyll ( $\triangle$ Chla) can be obtained by solving eq. (5) for all these organic substances. The time evolution of the different organic components are coupled at the short-time scale $\left(r^{2}=0.74-0.96\right)$. The $y$-intercept of the corresponding regression equations is not significantly different from zero (Table 3). The slope of the $\triangle P O C-\triangle P O N$ regression (6.3 \pm 0.2 ) agrees very well with the Redfield $\mathrm{C} / \mathrm{N}$ ratio for healthy phytoplankton, and it is $\sim 25 \%$ lower than the $\mathrm{C} / \mathrm{N}$ ratio of nutrients consumption. On the contrary, the corresponding $\mathrm{C} / \mathrm{P}$ ratio is $69 \pm 6$, about half of the $\Delta C_{T \mathrm{COR}} / \Delta P$ ratio of $135\left(=\mathrm{R}_{\mathrm{P}} / \mathrm{R}_{\mathrm{C}}\right)$. The slope of the $\Delta P O C-\Delta C h l a$

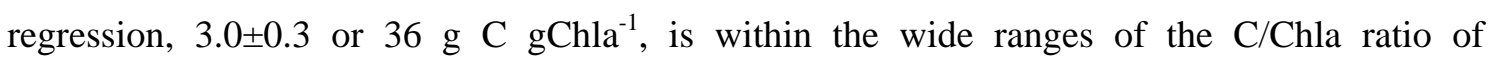
phytogenic organic matter reported in the literature (Antia et al., 1963; Ríos, 1992). A ratio of 40 is commonly used to convert chlorophyll to carbon in cultures of healthy phytoplankton (Eppley et al., 1977). The C/Chla ratio for diatoms species in the adjacent Ría de Vigo ranges from 35 to 50 (Ríos et al., 1998) and a value of 41 for diatoms was recorded by Eppley et al. (1977) in the upwelling of California.

\subsection{Contrasting $-\mathrm{O}_{2} / \mathrm{C} / \mathrm{N} / \mathrm{P} / \mathrm{Si}$ ratios under average upwelling and downwelling conditions.}

The upwelling season. The characteristic succession of wind stress-relaxation events during the upwelling season is observed from June 8 to October 12 (Fig. 5a). The average $I_{\mathrm{W}}$ for this period is $0.5 \mathrm{~m}^{2} \mathrm{~s}^{-1}$. As much as $5069 \mathrm{~m}^{3} \mathrm{~s}^{-1}$ of ENACW-rich shelf bottom water enters the ría during the upwelling season (Fig 6a). Half of them go into the upper layer in the vertical convective flow $\left(2540 \mathrm{~m}^{3} \mathrm{~s}^{-1}\right.$ or $\left.1.2 \mathrm{~m} \mathrm{~d}^{-1}\right)$ and the other half penetrate in the estuarine part of the ría, off the study volume. Considering the volume and the residual flows, the average residence time of water within the Ría is $\sim 6.3$ days. Vertical mixing represented $5205 \mathrm{~m}^{3} \mathrm{~s}^{-1}$ or $2.4 \mathrm{~m} \mathrm{~d}^{-1}$, twice the vertical convective flow. 
The average $\Delta C_{\mathrm{TCOR}}, \Delta N_{\mathrm{T}}, \Delta P$ and $\Delta S i$ for the upwelling season (Table 4) represent 1.4, 54, 39 and $25 \%$ of the total input of $\mathrm{C}_{\mathrm{T}}, \mathrm{N}_{\mathrm{T}}$, phosphate and silicate into the ría (Fig. 6b). Therefore, $\mathrm{N}_{\mathrm{T}}$ is the most efficiently trapped nutrient salt during the upwelling season into the Ría. Although the N/P and N/Si molar ratios in the subsurface ingoing flow are 15.5 and 1.46 respectively, they reduce to 10.7 and 0.84 in the surface outgoing flow. This reduction is due to the very high average $\Delta N_{\mathrm{T}}: \Delta P$ and $\Delta N_{\mathrm{T}}: \Delta S i$ (Table 4) compared with the expected values from the average composition of marine phytoplankton, 16 (Anderson, 1995) and 1 (Nelson et al., 1995) respectively. $\mathrm{O}_{2}$ delivered to the atmosphere was $22 \%$ of $\Delta \mathrm{O}_{2 \mathrm{COR}}$ and the remaining $78 \%$ enriches the surface outgoing flow. On the contrary, the $\mathrm{CO}_{2}$ flux to the atmosphere represents only $0.03 \%$ of the $\mathrm{C}_{\mathrm{T}}$ flux into the Ría and $2 \%$ of $\Delta C_{\mathrm{TCOR}}$. The average $R_{\mathrm{C}}$ and $R_{\mathrm{N}}$ are very close to the expected values for autotrophic synthesis of organic matter.

Net mineralization of $35 \%$ of $C_{\mathrm{T}}, 17 \%$ of $N_{\mathrm{T}}, 35 \%$ of phosphate and $57 \%$ of silicate consumed in the upper level occurs in the lower layer during the upwelling season, using $30 \%$ of oxygen produce in the upper layer. Nutrient consumption in the upper layer and mineralization in the lower layer contribute to increase the vertical gradient of nutrients, enhancing the vertical mixing fluxes and modifying the corresponding nutrient ratios. The N/P and N/Si ratios in the upward convective flow are 12.4 and 0.96 respectively. They are lower than in the bottom ingoing flow because of the mineralization ratios in the lower layer. On the contrary, these ratios in the mixing flow are 22 and 2.6 respectively, very close to the average net consumption ratios observed. Finally, the average N/P and N/Si ratios in the three upward flows $\left(Q_{\mathrm{Z}}, M_{\mathrm{Z}}\right.$ and $\left.Q_{\mathrm{E}}\right)$, i.e. the nutrient ratios feeding the phytoplankton population in the upper layer, are 15.8 and 1.4 respectively. Consequently, the large modification of the N/P and N/Si ratios within the ría occurs mainly in the upper layer.

Average $\triangle P O C, \triangle P O N$ and $\triangle P O P$ during the upwelling season (Table 4) represent an increase of 130, 90 and $100 \%$ compared with the corresponding organic loads in the bottom ingoing flow (Fig. 6c). Only 17\% of POC and PON and 6.5\% of POP produced in the upper layer is mineralised in the lower layer. $\triangle P O C$ and $\triangle P O N$ are $\sim 1 / 3$ of $\Delta C_{\mathrm{TCOR}}$ and $\Delta N_{\mathrm{T}}$ 
respectively, whereas $\triangle P O P$ is as much as $\sim 2 / 3$ of $\triangle P$. The average $\triangle P O C: \triangle P O N$ is $\sim 15 \%$ lower than the $\mathrm{C} / \mathrm{N}$ ratio of POM coming from the shelf, in such a way that the $\mathrm{C} / \mathrm{N}$ ratio in the surface outgoing flow is $\sim 8 \%$ lower than in the bottom ingoing flow. Therefore, during the upwelling season the ría is delivering to shelf surface water a large load of nitrogen-rich POM. On the contrary the organic N/P ratio in the bottom ingoing and the surface outgoing flows are quite similar at $\sim 11$. The average $\Delta$ Chla represents $\sim 280 \%$ of the Chla load in the bottom ingoing flow from the shelf.

The autumn downwelling. Intense southerly winds provoked strong downwelling form 13 to 30 of October (Fig $5 \mathrm{a}$ ). The average $I_{\mathrm{W}}$ for this period was $-0.5 \mathrm{~m}^{2} \mathrm{~s}^{-1}$, provoking a pronounced reversal in the circulation with the entry of shelf surface water into the ría (Fig. 7a). The values of $Q_{\mathrm{X} 7}, Q_{\mathrm{z}}$ and $Q_{\mathrm{xO}}$ are strongly negative, leading to a residence time of only 3.7 days in the volume studied. The circulation is still positive in the estuarine part of the ría. The vertical downward $\left(-6 \mathrm{~m} \mathrm{~d}^{-1}\right)$ and mixing $\left(3.4 \mathrm{~m} \mathrm{~d}^{-1}\right)$ flows are extremely high.

The average $\Delta C_{\mathrm{TCOR}}, \Delta N_{\mathrm{T}}, \Delta P, \Delta S i$ for the autumn downwelling are strongly positive, i.e. the hydrodynamic conditions favoured net nutrient mineralization in the volume considered (Table 4). About $21 \%$ of the $\mathrm{O}_{2}$ consumed during this period came from the atmosphere. Conversely, $\sim 8 \%$ of $\Delta C_{\mathrm{TCOR}}$ is lost to the atmosphere because of the very high surface $\mathrm{pCO}_{2}$ levels and the local strong winds (6 $\mathrm{m} \mathrm{s}^{-1}$; Rosón et al, 1999). Although the average $R_{\mathrm{N}}$ is close the revised Redfield value, $R_{\mathrm{C}}, \Delta N_{\mathrm{T}}: \Delta P$ and $\Delta N_{\mathrm{T}}: \Delta S i$ are low. Most of the mineralization occurs in the upper box: 89, 103, 98 and $71 \%$ of $\mathrm{C}_{\mathrm{T}}, \mathrm{N}_{\mathrm{T}}$, phosphate and silicate. As a consequence of the nutrient mineralization ratios, the high N/P ratio in the surface ingoing flow (13.6) decreased to 12.6 in the to the bottom outgoing flow. Conversely, the very low N/Si ratio of 0.69 in the surface ingoing flow increases to 0.93 in the bottom outgoing flow.

The $\triangle P O C: \triangle P O N$ and $\triangle P O N: \triangle P O P$ during the mineralization of the organic matter in the volume studied (Table 4) are close to the Redfield values. Chla entering the ría in the surface incoming flow is mineralised at an average rate of $8.6 \mathrm{~g} \mathrm{~s}^{-1}$, being the $\triangle P O C: \triangle C h l a$ mass ratio as high as 125 . 


\subsection{Parametrising the NEP of the Ría de Arousa}

Since the time courses of $\Delta C_{\mathrm{TCOR}}, \Delta N_{\mathrm{T}}$ and $\Delta P$ are parallel to $\Delta O_{2 \mathrm{COR}}$, we have converted $-\Delta C_{\mathrm{TCOR}},-\Delta N_{\mathrm{T}}$ and $-\Delta P$ into $\mathrm{mmol} \mathrm{m}^{-2} \mathrm{~d}^{-1}$ of $\mathrm{O}_{2}$ (Fig. 3a), using the linear regressions in Table

3. The average net oxygen production rates obtained from the four series of independent values $\left(C_{\mathrm{TCOR}}, N_{\mathrm{T}}, P\right.$ and $\left.\mathrm{O}_{2 \mathrm{COR}}\right)$ can be considered the net ecosystem production of the Ría $(<N E P>$ ), i.e. the primary production minus the respiration of autothrophus and all heterothropus in the volume studied (Smith and Hollibaugh, 1997). In the same way, $\triangle P O N, \triangle P O P$ and $\triangle C h l a$ have been converted into mmol m${ }^{-2} \mathrm{~d}^{-1}$ of POC (Fig. 3b) using the corresponding regressions in table 3 to obtain an average POC production rate $(<P O C>)$. Although the time evolutions are quite parallel, the direct correlation between $<N E P>$ and $<P O C>$ is not so good, $r^{2}=0.58$ (Fig. 4). If $<N E P>$ is converted into carbon units, the slope of the correlation with $<P O C>(0.33)$ indicates that only $1 / 3$ of the NEP is transformed into exportable POC along the study period.

The seven major $<N E P>$ maxima in Fig. 3b (ranging from 200 to $400 \mathrm{mmol} \mathrm{m}^{-2} \mathrm{~d}^{-1}$ ) occur one sampling (3-4 days) after the periodic entries of nutrient-rich ENACW. The time evolution of the Ekman transport $I_{\mathrm{W}}$ (Fig. 5a) — which forces ENACW into the ría - is a succession of peaks (upwelling) and toughs (relaxation) with a periodicity of $14 \pm 4 \mathrm{~d}$ (Álvarez-Salgado et al., 1993). Upwelling relaxations are accompanied by $<N E P>$ minima (ranging from 0 to $-75 \mathrm{mmol} \mathrm{m} \mathrm{d}^{-1}$ ) in between two maxima. Large negative values of $I_{\mathrm{W}}$ at the end of the study period indicate strong downwelling conditions coinciding with the pronounced minimum of $\langle\mathrm{NEP}\rangle=-116 \mathrm{mmol} \cdot \mathrm{m}^{-2} \cdot \mathrm{d}^{-1}$. The stability of the water column (average depth-integrated Brunt-Väisälä frequency, BV) also contribute to module the NEP of the ría: it reduce the vertical diffusive flux of nutrients to the photic layer during upwelling relaxations and increases the efficiency of nutrient uptake by primary producers during upwelling events. As a general trend, $B V$ increases during relaxations and decreases during upwelling or downwelling conditions (Fig. 5c). The observed decreasing trend along the study period $\left(r^{2}=0.64, \mathrm{n}=45, p<0.0001\right)$ is probably associated to the decreasing heat exchange flux $F_{\mathrm{Q}}$ (Fig. 5b). Such a general decreasing trend of $-0.7 \mathrm{mmol} \mathrm{m}^{-2} \mathrm{~d}^{-1}$ is observed in $\langle N E P>$ as 
well $\left(r^{2}=0.27 n=46, p<0.08\right)$. Therefore, we have tried to quantify the influence of upwelling, stability and heat flux on the NEP looking for the linear combination of $I_{\mathrm{W}}, B V$ and $F_{\mathrm{Q}}$ which explains better the time evolution of $\left\langle N E P>\right.$. The best fit $\left(r^{2}=0.70\right)$ was obtained with the equation:

$$
<N E P>=70( \pm 16) \cdot I \mathrm{w}_{12}-35( \pm 14) \cdot I \mathrm{w}_{0}+0.38( \pm 0.06) \cdot\left(F \mathrm{Q}_{0}+F \mathrm{Q}_{1}\right)-(198 \pm 37) \cdot B V
$$

where $B V, I \mathrm{w}_{0}$ and $F_{\mathrm{Q}_{0}}$ are the average Brünt-Väisälä frequency $\left(\mathrm{min}^{-1}\right)$, Ekman transport $\left(\mathrm{m}^{2}\right.$ $\mathrm{s}^{-1}$ ) and heat exchange flux $\left(\mathrm{cal} \mathrm{cm}^{-2} \mathrm{~d}^{-1}\right)$ from $\mathrm{t}_{\mathrm{j}-1}$ to $\mathrm{t}_{\mathrm{j}} ; F_{\mathrm{Q}_{1}}$ is the average $F_{\mathrm{Q}}$ from $\mathrm{t}_{\mathrm{j}-2}$ to $\mathrm{t}_{\mathrm{j}-1}$; and $I \mathrm{w}_{12}$ is the average $I_{\mathrm{W}}$ from $\mathrm{t}_{\mathrm{j}-3}$ to $\mathrm{t}_{\mathrm{j}-1}$. The river input does not contribute significantly to explain the variance of $\langle N E P>$. Fig. $5 d$ compares the $<N E P>$ rates in Fig. 3a with those calculated with eq. 11. It shows the good agreement between the NEP calculated from the time variability of thermohaline and biogeochemical properties, and the NEP parametrised using the external physical forces of the ecosystem (upwelling and irradiance) and the stability of the water column.

\section{Discussion and conclusions}

\subsection{The dramatic effect of hydrography on the $\mathrm{O}_{2} / C / N / P / S i$ stoichiometry of $N E P$}

Pronounced differences have been observed between the N/P ratios of net nutrient uptake and organic matter production during the upwelling season. The average $\Delta N_{\mathrm{T}} / \Delta P$ is $\sim 30 \%$ higher than and the $\triangle P O N / \triangle P O P$ is $\sim 30 \%$ lower than the expected value of 16 during the synthesis of the organic tissues of marine phytoplankton (Laws, 1991; Anderson, 1995; Fraga et al., 1998). Conversely, $R_{\mathrm{N}}$ keeps the expected ratio during phytoplankton production. The well-known longer recycling times of nitrogen compared with phosphorus (Harrison, 1980; Garber, 1984) could explain the high average N/P ratio during the net uptake of $\mathrm{N}_{\mathrm{T}}$ and phosphate in the $\sim 6$ days average residence time within the study volume. The same behaviour has been recorded by Nogueira et al. (1997) in the adjacent Ría de Vigo. In this sense, Treguer and Le Corre (1979), who obtained a N/P ratio of 18.5 during nutrient uptake, observed that phosphorous regeneration is $\sim 30 \%$ faster than nitrogen regeneration mediated by zooplankton 
or animal excretion in the upwelling off Morocco. Conversely, the low N/P ratio of the suspended organic matter produced, concomitant with a Redfield $\mathrm{C} / \mathrm{N}$ ratio, indicates a substantial contribution of detritus colonised by bacteria, which is probably related with the intensive hanging mussel culture. Low N/P ratios in suspended organic matter were observed during an annual cycle in the Ría de Vigo (average, 12.8). Detritus represented 24\% of the suspended material (Ríos et al., 1998). Accordingly, Copin-Montégut and Copin-Montégut (1983) observed very low C/P ratios in suspended organic matter of the NW Africa upwelling system.

The extremely low average $\Delta N_{\mathrm{T}} / \Delta P=7.4$ during downwelling conditions contrasts with the N/P ratio of the mineralised suspended organic matter. The same behaviour was observed by Howarth (1988) in Narragansett Bay, where suspended organic matter enters the sediments with a N/P ratios of 16 , but nutrient are released back to the water column with a ratio of 6 . In addition, the N/P ratio of mineralised nutrients in the NW and SW Africa upwelling systems ranges from 8 to 12 (Jones, 1971; Rowe et al., 1977; Treguer and Le Corre, 1979). Since the $R_{\mathrm{N}}=10.0$ observed in the Ría de Arousa during the downwelling event is within the expected ranges during the oxidation of phytogenic organic matter in oxic conditions, denitrification processes within the sediments seems not to be the reason behind the low $\Delta N_{\mathrm{T}} / \Delta P$. Therefore, the most likely explanations have to be the faster recycling rates of phosphorus within the sediments, or the alternative hypothesis of phosphate release from interstitial water by processes independent of organic matter oxidation (Suess, 1981). The short residence time of upwelled ENACW in the Ría precludes denitrification, which occurs in estuarine system with long residence time as Tomales Bay in the upwelling region of California (Smith and Hollibaugh, 1997).

The average N/Si net uptake ratio during the upwelling season (3.2) was much higher than the expected value from the average composition of marine diatoms ( 1; Brezinski, 1985; Nelson et al., 1995). Pazos et al. (1995) have demonstrated that the periodic wind stress/relaxation sequence selected the microplankton species inside the Ría de Arousa, which 
results in the annual succession from small pioneer diatoms to red-tide species occurring several times during the upwelling season 1989. Therefore, non-siliceous species have a relevant contribution to the phytoplankton population in the ría, which increases the average N/Si ratio. In the upwelling of Monterrey Bay (California), direct measurements of nitrate and silicate uptake yields $\mathrm{N} / \mathrm{Si}$ ratios ranging from 0.8 under upwelling conditions to 10 under nutrient depletion (White and Dugdale, 1997). In the NW Africa upwelling system, Treguer and Le Corre (1979) obtained a very low ratio of 0.33 using a simple water-masses mixing linear model.

The average N/Si net mineralization ratio during the autumn downwelling decreases to 1.0, pointing to the dissolution of the diatom frustules deposited into the Ría de Arousa. Following Chapman and Shannon (1985), the main reason for the silicate increase that they found in shelf bottom waters off Namibia is the dissolution of silica, which has been deposited either as zooplankton faeces or as undigested diatom frustules. In the case of the Rías Baixas, the contribution of the extensive bottom biodeposits generated by mussel cultured on hanging ropes have to be considered as well (Tenore et al., 1982). In this sense, large opal deposits have been observed in shelf sediments of the NW Iberian Peninsula (Prego and Bao, 1997). Álvarez-Salgado et al. (1997) found N/Si mineralization ratios of 1.2-1.5 in shelf waters off the rías and values ranging from 0.7 to 1.2 have been observed in the NW Africa upwelling system (Treguer and Le Corre, 1979; Friedrerich and Codispoti 1979).

The average $\mathrm{C} / \mathrm{N}$ net uptake ratio by the community of organisms into the Ría de Arousa during the upwelling season (6.9) is slightly higher than the average $\mathrm{C} / \mathrm{N}$ net production ratio of suspended organic matter (6.3). Since suspended organic matter represents only $\sim 1 / 3$ of the total $\Delta C_{\mathrm{TCOR}}$ and $\Delta N_{\mathrm{T}}$, the remaining organic matter produced (dissolved and deposited) must have an average C/N ratio of 7.2. Álvarez-Salgado et al. (1996a) and Rosón et al. (1999) reported that $\sim 17 \%$ of the net uptake of $\mathrm{C}_{\mathrm{T}}$ and $\mathrm{N}_{\mathrm{T}}$ sedimented to the bottom and the remaining $50 \%$ was in the form of dissolved organic matter because of the intensive culture of mussels on hanging ropes. On the contrary, the average $\mathrm{C} / \mathrm{N}$ ratio of the nutrients mineralised during 
the autumn downwelling event is as high as 9.9 , whereas the $\mathrm{C} / \mathrm{N}$ ratio of the suspended organic matter mineralised keeps at 6.7. As for the previous cases, diffusion to the water column of $\mathrm{CO}_{2}$ produced during the mineralization of $\mathrm{C}$-rich organic matter deposited in the pelagic sediments of the ría have to be the reason behind the observed inorganic $\mathrm{C} / \mathrm{N}$ ratio. Álvarez-Salgado et al. (1996a) and Rosón et al. (1999) suggested the pelagic sediments of the Ría as a primary source of $\mathrm{C}_{\mathrm{T}}$ and $\mathrm{N}_{\mathrm{T}}$ to the water column, since $\mathrm{C}_{\mathrm{T}}$ and $\mathrm{N}_{\mathrm{T}}$ production exceeded organic matter consumption. The oxygen consumption and the silicate and phosphate production reported in the present work also support the key role of pelagic sediments during downwelling events. These results are in agreement with the general statement that continental shelf sediments over-world play a key role in nutrient mineralization processes (Rowe et al., 1975; Howarth, 1988; Christensen, 1994).

\subsection{The hydrodynamic control of NEP in an estuarine upwelling ecosystem}

The NEP of the Ría de Arousa depends strongly on the water column response to the variability of shelf wind-stress, as usually observed in coastal upwelling systems. The high productivity and the coupling of the circulation in the embayment with coastal upwelling make the Ría de Arousa an ideal scenario to parameterise the effect of the external forces on the productivity.

Coastal upwelling affects the productivity of the embayment in two contrasting ways. The average $I_{\mathrm{W}}$ during the 6-7 days before any of the short periods (3-4 days) considered ('previous upwelling', $I \mathrm{w}_{12}$ ) enhances the productivity because of the introduction of nutrient-rich ENACW into the embayment. On the contrary, the average $I_{\mathrm{W}}$ during the study periods ('instantaneous upwelling', $I \mathrm{w}_{0}$ ) depresses the productivity of the system because of the concomitant reduction of the residence time within the embayment. This 'washing-out effect does not allow the new phytoplankton population in the upwelled water to adapt to the new light conditions (Zimmerman et al. 1987). Since the coefficient of $I \mathrm{w}_{0}$ is a half of the coefficient of $I \mathrm{w}_{12}$, an 'instantaneous upwelling' of the same order than the 'previous 
upwelling' will be able to reduce the productivity by a half. The combination of $I \mathrm{w}_{0}$ and $I \mathrm{w}_{12}$ constitutes $\sim 43 \%$ of the explained variance.

The heat-exchange flux across the sea surface contribute positively to the productivity of the embayment in two manners. $F_{Q_{1}}$ increases the thermal stability of the water column during the 3-4 days before the short periods considered, which contributes to reduce the 'washing-out' effect associated to $I \mathrm{w}_{12}$. The combination of high $I \mathrm{w}_{12}$ and high $F \mathrm{Q}_{1}$ produces a quite favourable situation in which nutrients are injected by upwelling and the light-adapted phytoplankton population in the photic layer is not 'washed out' and replaced by the new population transported by the upwelled water (Huntsman and Barber, 1977). In addition, FQ is related to the availability of light for phytoplankton growth during the short study periods since the formulae used to calculate $F_{\mathrm{Q}}$ includes the day-length an a correction for cloudiness. $\mathrm{FQ}_{0}$ and $\mathrm{FQ}_{1}$ increases to $\sim 80 \%$ the percentage of the explained variance.

The remaining $20 \%$ of the explained variance is achieved when the stability of the water column during the sampling period is considered. $B V$ contributes to reduce the productivity of the system since a well-developed pycnocline prevents the entry of nutrients into the photic layer by turbulent diffusion under non-wind-forced conditions. The same behaviour has been observed by Haapala (1994) in the Gulf of Finland.

\section{Acknowledgements}

The authors wish to thank all the participants in the Galicia- $X$ cruise from the Instituto de Investigacións Mariñas and the crew of the R/V Investigador S., for their valuable help. We are very grateful to S.V. Smith and two anonymous reviewers for their valuable comments and criticisms on the earlier version of the manuscript. Support for this work came from C.I.C.Y.T. Grant No MAR88-0245 and funds from the Conselleria de Pesca da Xunta de Galicia. 


\section{References}

Álvarez-Salgado, X.A., Rosón, G., Pérez, F.F., Pazos, Y., 1993. Hydrographic variability off the Rías Baixas (NW Spain) during the upwelling season. J. Geophys. Res. 98(C8), $14447-14455$.

Álvarez-Salgado, X.A., Rosón, G., Pérez, F.F., Figueiras, F.G., Pazos, Y., 1996a. Nitrogen cycling in an estuarine upwelling system, the Ría de Arousa (NW Spain). I: short-time-scale evolution of hydrodynamic and biogeochemical circulation of nitrogen species. Mar. Ecol. Progr. Ser. 135, 259-273.

Álvarez-Salgado, X.A., Rosón, G., Pérez, F.F., Figueiras, F.G., Ríos, A.F., 1996b. Nitrogen cycling in an estuarine upwelling system, the Ría de Arousa (NW Spain). II. Spatial differences in the short-time-scale evolution of fluxes and net budgets. Mar. Ecol. Prog. Ser. 135, 275-288.

Álvarez-Salgado, X.A., Castro, C.G., Pérez, F.F., Fraga, F., 1997. Nutrient mineralization patterns in shelf waters of the NW Iberian upwelling system. Cont. Self Res. 17, 1247-1270.

Anderson, L.A., 1995. On the hydrogen and oxygen content of marine phytoplankton. Deep-Sea Res. I 42, 1675-1680.

Anderson, L.A., Sarmiento, J.L., 1994. Redfield ratios of mineralization determined by nutrient data analysis. Global Biogeochemical Cycles 8, 65-80.

Antia, N.J., McAllister, C.D., Parsons, T.R., Stephens, R., Strickland, J.D.H., 1963. Further measurements of primary production in coastal sea water using large volume plastic sphere. Limnol. Oceanogr. 6: 237-258.

Bakun, A., 1973. Coastal upwelling indices, west coast of North America 1946-1971. NOAA technical report, NMFSSSRF-671, 103 pp

Blanton, J.O., Tenore, K.R., Castillejo, F.F., Atkinson, L.P., Schwing, F.B., Lavín, A., 1987. The relationship of upwelling to mussel production in the rías on the western coast of Spain. J. Mar. Res. 45, 497-511.

Broecker, W.S., Peng, T.-H, 1982. Tracers in the Sea, Eldigio Press, New York, 690 pp. 
Brzezinski, M.A., 1985. The Si:C:N ratios of marine diatoms: Interspecific variability and the effect of some environmental variables. J. Phycol. 21, 347-357.

Castro, C. G., Pérez F.F., Holley S., Ríos A.F., 1998. Characterization and modelling of water masses in the Northeast Atlantic. Progr. Oceanog., 41(3), 249-279.

Chapman, P., Shannon, L.V., 1985. The Benguela ecosystem, Part II. Chemistry and related processes. Oceanography and Marine Biology Annual Reviews, 23, 183-251.

Copin-Montégut, C. and Copin-Montégut, G., 1983. Stoichiometry of carbon, nitrogen, and phosphorus in marine particulate matter. Deep Sea Res. I, 30: 31-46.

Christensen, J.P., 1994. Carbon export from continental shelves, denitrification and atmospheric carbon dioxide. Cont. Shelf Res. 14, 547-576.

Doval, M.D., Álvarez-Salgado, X.A., Pérez, F.F., 1997. Dissolved organic carbon in an coastal embayment affected by upwelling. Mar. Ecol. Prog. Ser. 157, 21-37.

Eppley R.W., Harrison, W.H., Chisholm, S.W., Stewart, E., 1977. Particulated organic matter in surface water off southern California and its relationship to phytoplankton. J. Mar. Res. 34, 671-696.

Fraga, F., 1981, Upwelling off the Galician Coast, Northwest Spain. In: Coastal Upwelling Series, vol. 1, F.A. Richards, editor, AGU, Washington D.C., pp. 176-182.

Fraga, F., Pérez, F.F., 1990. Transformaciones entre composición química del fitoplancton, composición elemental y relación de Redfield. Scient. Mar. 54, 69-76.

Fraga, F., Pérez, F.F., Figueiras, F.G., Ríos, A.F., 1992, Stoichiometric variations of N, P, C, and $\mathrm{O}_{2}$ during a Gymnodinium catenatum red tide and their interpretation. Mar. Ecol. Prog. Ser. 87, 123-134.

Fraga, F., Ríos, A.F., Pérez, F.F., Figueiras, F.G., 1998. Theoretical limits of oxygen:carbon and oxygen:nitrogen ratios during photosynthesis and mineralisation of organic matter in the sea. Sci. Mar. 62, 161-168.

Friederich, G.E., Codispoti, L.A., 1979. On some factors influencing dissolved silica distribution over the northwest African shelf. J. Mar. Res. 37, 337-353. 
Garber, J.H., 1984. Laboratory study of nitrogen and phosphorus remineralization during the decomposition of coastal plankton and seston. Estuar. Coastal shelf Sci. 18, 685-702.

Haapala, J., 1994. Upwelling and its Influence on nutrient concentration in the coastal area of the Hanko Peninsula, entrance of the Gulf of Finland. Estuar. Coastal Shelf Sci. 38, 507-521.

Harrison, W.G., 1980. Nutrient regeneration and primary production in the sea. In: Falkowski, P.G. (Ed.), Primary Productivity in the Sea, Plenum Press, New York, pp. 433-460.

Howarth, R.W., 1988. Nutrient Limitation of net Primary Production in marine ecosystems. Ann. Rev. Ecol. 19, 89-100.

Huntsman, S.A., Barber, R.T., 1977. Primary production off northwest Africa: the relationship to wind and nutrient conditions. Deep-Sea Res. 24, 25-33.

Jones, P.G.W., 1971. The Southern Benguela Current region in February, 1966: Part. I. Chemical observations with particular reference to upwelling. Deep-Sea Res. 18, 193-208.

Kester D.R., 1975. Dissolved gases other than $\mathrm{CO}_{2}$. In: Chemical Oceanography (Second Edition). Riley J.P. and Skirrow (editors)., 1, 497-556.

Laws, E., 1991. Photosynthetic quotients, new production and net community production in the open ocean. Deep-Sea Res. 38, 143-167.

López-Jamar, E., Cal, R.M., González, G., Hanson, R.B., Rey, J., Santiago, G., Tenore, K.R., 1992. Upwelling and outwelling effects on the benthic regime of the continental shelf off Galicia, NW Spain. J. Mar. Res. 50, 465-488.

Matsukawa, Y., Suzuki, T., 1985. Box model analysis of hydrographic behaviour of nitrogen and phosphorus in a eutrophic estuary. J. Oceanogr. Soc. Japan 41 407-426.

Minster, J.-F., Boulahdid, M., 1987. Redfield ratios along isopycnal surfaces-a complementary study. Deep-Sea Res. 34, 1981-2003.

Millard, R.C., Owens, W.B., Fofonoff, N.P., 1990. On the calculations of the Brunt-Väisälä frequency. Deep-Sea Res. 37, 167-181.

Nelson, D.M., Tréguer, P., Brzezinski, M.A., Leynaert, A., Quéguiner, 1995. Production and dissolution of biogenic silica in the ocean: revised global estimates, comparison with 
regional data and relationship to biogenic sedimentation. Global Biogeochemical Cycles 9, 359-372.

Nogueira, E., Pérez F.F., Ríos A.F., 1997. Seasonal patterns and long-term trends in an estuarine upwelling ecosystem (Ría de Vigo, NW Spain). Estuar. Coastal Shelf Sci. 44. 285-300.

Otto, L, 1975. Oceanography of the Ría de Arousa (NW Spain). Konink Meteor Int Med Verlan 96

Pazos, Y., Figueiras F.G., Álvarez-Salgado X.A., Rosón, G., 1995. The control of succession in red tide species in the Ría de Arousa (NW Spain) by upwelling and stability. In: Lassus P, Arzul G, Erad E, Gentien P, Marcaillou C (eds), Harmful Algal Blooms. Lavoisier, Intercept Ltd, p 645-650.

Pérez, F.F., Mouriño, C., Fraga, F., Ríos, A.F, 1993. Displacement of water masses and remineralization rates off the Iberian Peninsula by nutrient anomalies. J. Mar. Res. 51, 869-892.

Prego, R., 1994. Nitrogen interchanges generated by biogeochemical processes in a Galician ría. Mar. Chem. 45, 167-176.

Prego, R., Bao, R., 1997. Upwelling influence on the Galician coast: silicate in shelf water and underlying surface sediments. Cont. Shelf Res. 17, 307-218.

Redfield, A.C., Ketchum, B.H., Richards, F.A., 1963. The influence of organisms on the composition of sea-water. In: The Sea, vol. 2, M.N. Hill, editor, Wiley and Sons, pp. 26-77.

Ríos, A.F., 1992. El fitoplancton de la Ría de Vigo y sus condiciones ambientales. Ph. D. Thesis. University of Santiago de Compostela, 416 pp.

Ríos A.F., Fraga, F, Pérez, F.F., Figueiras, F.G., 1998. Chemical composition of phytoplankton and particulated organic matter in Ria de Vigo (NW Spain). Sci. Mar. 62, 257-271.

Rosón, G., Álvarez-Salgado, X.A., Pérez, F.F., 1997. A non-stationary box-model to determine residual flows in a partially mixed estuary, based on both thermohaline properties. Application to the Ría de Arousa (NW Spain). Estuar. Coastal Shelf Sci. 44, 249-262. 
Rosón, G., Álvarez-Salgado, X.A., Pérez, F.F., 1999. Carbon cycling in a large coastal embayment, affected by wind-driven upwelling: short-time-scale variability and spatial differences. Mar. Ecol. Prog. Ser. 176, 215-230.

Rosón, G., Pérez, F.F., Álvarez-Salgado, X.A., Figueiras, F.G., 1995. Variation of both thermohaline and chemical properties in an estuarine upwelling ecosystem: Ría de Arousa. l. Time Evolution. Estuar. Coastal Shelf Sci. 41, 195-213.

Rowe, G.T., Clifford, C.H., Smith Jr., K.L., Hamilton, P.L., 1975. Benthic nutrient regeneration and its coupling to primary productivity in coastal waters. Nature 255, 215-217.

Rowe, G.T., Clifford, C.H., Smith Jr., K.L., Hamilton, P.L. 1977. Regeneration of nutrients in sediments off Cape Blanc, Spanish Sahara. Deep-Sea Res. 24, 57-64.

Sambrotto, R.N., Savidge, G., Robinson, C., Boyd, P., Takahashi, T., Karl, D.M., Langdon, C., Chipman, D., Marra, J., Codispoti, L., 1993. Elevated consumption of carbon relative to nitrogen in the surface ocean. Nature 363, 248-250.

Smith, S.V., Hollibaugh, J.T., 1997. Annual cycle and interannual variability of ecosystem metabolism in a temperate climate embayment. Ecological Monographs 67, 509-533.

Sockal, R.R., Rolhf, F.J., 1995. Biometry. Freeman and Company (eds), New York, 887pp

Sverdrup, H.U., Johnson, M.W., Fleming, R.H. 1942. The Oceans, their Physics, Chemistry and General Biology. Prentice-Hall, New York, 1087 pp.

Suess, E., 1981. Phosphate regeneration from sediments of the Perú continental margin by dissolution of fish debris. Geochim. Cosmochim. Acta 45, 577-588.

Takahashi, T., Broecker, W.S., Langer, S., 1985. Redfield ratio based on chemical data from isopycnal surfaces. J. Geophys. Res. 90, 6907-6924.

Tenore, K.R., plus 14 authors, 1982. Coastal upwelling in the Rías Baixas, NW Spain. Contrasting the benthic regimes of the Ría de Arousa and Muros. J. Mar. Res. 40, 701-772.

Tenore, K.R. plus 18 authors (1995) Fisheries and Oceanography off Galicia, NW Spain: Mesoscale spatial and temporal changes in physical processes and resultant patterns of biological productivity. J. Geophys. Res., 100, 10943-10966. 
Treguer, P., Le Corre, P., 1979. The ratios of nitrate, phosphate and silicate during uptake and regeneration phases of the Moroccan upwelling regime. Deep-Sea Res. 26, 163-184.

UNESCO (1985) The international system of units (SI) in oceanography. UNESCO Technical Papers on Marine Science 45, 1-124.

Walsh, J.J., 1991. Importance of continental margins in the marine biogeochemical cycling of carbon and nitrogen. Nature 359, 53-55.

Weis, R.F., 1974. Carbon dioxide in water and seawater: the solubility of a non-ideal gas. Mar. Chem. 2, 203-215.

White, K.K., Dugdale, R.C., 1997. Silicate and nitrate uptake in the Monterey Bay upwelling system. Cont. Shelf Res. 17, 455-472.

Wollast, R., 1991. The coastal organic carbon cycle: Fluxes, sources and sinks. In: Mantoura R.F.C., Martin, J.-M., Wollast, R. (Eds.), Ocean margin processes in global change. J Wiley \& Sons, p 365-381.

Wollast, R., 1993. Interactions of carbon and nitrogen cycles in the coastal zone. In: Wollast R., Mackenzie F.T., Chou L. (Eds), Interactions of C, N, P and S Biogeochemical Cycles and Global Change, Berlin, p 195-210.

Woolf D.K., Thorpe S.A. 1991. Bubbles and the air-sea exchange of gases in near-saturation conditions. J. Mar. Res. 49:435-466

Wooster, W.S., Bakun, A., McClain, D.R., 1976. The seasonal upwelling cycle along the eastern boundary of the North Atlantic. J. Mar. Res. 34, 131-141.

Zimmerman, R.C., Kremer, J.N., Dugdale, R.C., 1987. Acceleration of nutrient uptake by phytoplankton in a coastal upwelling ecosystem: a modelling analysis. Limnol. Oceanogr. 32, 359-367. 


\section{Figure captions}

Fig. 1. Chart of the survey area, the Ría de Arousa (NW Spain), indicating the position of the ten sites where seawater samples were collected. The 20 and 50m isobaths are shown. Lines crossing stations $1,8,7$ and 10 are the boundaries of the study box.

Fig. 2. The 2-D box model. The study box is divided in an upper and a lower layer, separated by a level-of-no-motion, which coincides with the pycnocline. $Q_{\mathrm{x} 1}$ and $Q_{\mathrm{x} 8}$ are the surface horizontal convective flows into the study box from the Ulla and Umia estuaries; $Q_{\mathrm{X} 7}$ is the surface horizontal convective flow from the mouth of the Ría de Arousa to shelf surface waters; $Q_{\mathrm{xo1}}$ and $Q_{\mathrm{xos}}$ are the compensating bottom convective flows from the study box into the Ulla and Umia estuaries; $Q_{\mathrm{x} 07}$ is the compensating bottom flow from the shelf into the lower layer of the study box; $Q_{\mathrm{Z}}$ and $Q_{\mathrm{E}}$ and $M$ are the vertical convective, entrainment and turbulent mixing flows from the lower to the upper layer of the study box; $Q_{\mathrm{R}}+P-E$ is the balance of runoff, precipitation and evaporation in the study box and; $F_{\mathrm{Q}}$ the heat exchange flux across the sea surface.

Fig. 3. Time-course of (a) $\Delta C_{\mathrm{TCOR}}, \Delta N_{\mathrm{T}}, \Delta P$ and $\Delta O_{2 \mathrm{COR}}$ in mmol m $\mathrm{m}^{-2} \mathrm{~d}^{-1}$ of oxygen and (b) $\triangle P O C, \triangle P O N, \triangle P O P$ and $\triangle C h l a$ in $\mathrm{mmol} \mathrm{m}^{-2} \mathrm{~d}^{-1}$ of carbon. The linear equations in Table 3 were used to convert inorganic carbon, nitrogen and phosphorus data into $\mathrm{O}_{2}$ units and organic nitrogen phosphorus and Chla data into carbon units. The solid lines represent the average oxygen $(<N E P>)$ and organic carbon production $(<P O C>)$ obtained from the independent budgets of $\mathrm{C}_{\mathrm{T}}, \mathrm{N}_{\mathrm{T}}, \mathrm{P}$ and $\mathrm{O}_{2}$ and POC, PON, POP and Chla, respectively.

Fig. 4. Short-time-scale (3-4 days) average net production of particulate organic matter versus average net ecosystem production in the study box . Units, mmol m $\mathrm{m}^{-2} \mathrm{~d}^{-1}$ of carbon.

Fig. 5. Time-course of (a) Ekman transport, $I_{\mathrm{W}}$; (b) heat-exchange flux across the sea surface, $F_{\mathrm{Q}}$; (c) average depth-integrated Brunt-Väisälä frequency, $B V$; and (d) average $(<N E P>)$ and modelled net ecosystem production. $B V=\sqrt{\frac{g}{Z / 2}} \cdot \ln \frac{\rho_{L}}{\rho_{U}}$, where $g$ is the gravity 
acceleration, $Z$ is the average depth of the study volume in the Ría de Arousa (23 m) and $\rho_{\mathrm{L}}$ and $\rho_{\mathrm{U}}$ the density of the lower and upper layers, respectively (Millard et al. 1990).

Fig. 6. Average (a) residual flows; (b) inorganic salts and oxygen fluxes; and (c) particulate organic matter fluxes during the upwelling season (June 8 to October 13, 1989). $Q_{\mathrm{X}}, Q_{\mathrm{xo}}$, $Q_{\mathrm{Z}}, Q_{\mathrm{E}}, M_{\mathrm{Z}}$ and $Q_{\mathrm{R}}+P-E$ in $\mathrm{m}^{3} \mathrm{~s}^{-1}$. Nutrient and organic mater fluxes in mol s $\mathrm{s}^{-1}$.

Fig.7. Average (a) residual flows; (b) inorganic salts and oxygen fluxes; and (c) particulate organic matter fluxes during the autumn downwelling (October 13 to 30, 1989). $Q_{\mathrm{x}}, Q_{\mathrm{xo}}$, $Q_{\mathrm{Z}}, Q_{\mathrm{E}}, M_{\mathrm{Z}}$ and $Q_{\mathrm{R}}+P-E$ in $\mathrm{m}^{3} \mathrm{~s}^{-1}$. Nutrient and organic mater fluxes in $\mathrm{mol} \mathrm{s} \mathrm{s}^{-1}$. 
Table 1. Summary of the average concentration of the measured variables during the hydrographic sampling in the Ría de Arousa from 8 June to 30 October 1989in the upper (up) and lower (low) layers of the study box (Fig. 2).

\begin{tabular}{|c|c|c|c|c|c|c|c|c|c|c|c|c|c|c|c|c|c|c|c|c|c|c|c|c|}
\hline \multirow{2}{*}{$\begin{array}{c}\text { Day } \\
\text { of } \\
1989 \\
\end{array}$} & \multicolumn{2}{|c|}{ salinity } & \multicolumn{2}{|c|}{$\begin{array}{c}\text { temperature } \\
\left({ }^{\circ} \mathrm{C}\right)\end{array}$} & \multicolumn{2}{|c|}{$\begin{array}{c}\text { alkalinity } \\
\left(\mu \mathrm{mol} \cdot \mathrm{kg}^{-1}\right)\end{array}$} & \multicolumn{2}{|c|}{$\begin{array}{c}\mathbf{C}_{\mathbf{T}} \\
\left(\mu \mathrm{mol} \cdot \mathrm{kg}^{-1}\right)\end{array}$} & \multicolumn{2}{|c|}{$\begin{array}{c}\mathbf{O}_{2} \\
\left(\mu \mathrm{mol} \cdot \mathrm{kg}^{-1}\right)\end{array}$} & \multicolumn{2}{|c|}{$\begin{array}{c}\text { Chl-a } \\
\left(\mu \mathrm{g} \cdot \mathrm{l}^{-1}\right)\end{array}$} & \multicolumn{2}{|c|}{$\begin{array}{c}\mathbf{H P O}_{4}{ }^{2-} \\
\left(\mu \mathrm{mol} \cdot \mathrm{kg}^{-1}\right)\end{array}$} & \multicolumn{2}{|c|}{$\begin{array}{c}\mathbf{S i}(\mathbf{O H})_{4} \\
\left(\mu \mathrm{mol} \cdot \mathrm{kg}^{-1}\right)\end{array}$} & \multicolumn{2}{|c|}{$\begin{array}{c}\mathbf{N}_{\mathbf{T}} \\
\left(\mu \mathrm{mol} \cdot \mathrm{kg}^{-1}\right)\end{array}$} & \multicolumn{2}{|c|}{$\begin{array}{c}\text { POC } \\
\left(\mu \mathrm{mol} \cdot \mathrm{l}^{-1}\right)\end{array}$} & \multicolumn{2}{|c|}{$\begin{array}{c}\text { POP } \\
\left(\mu \mathrm{mol} \cdot \mathrm{l}^{-1}\right)\end{array}$} & \multicolumn{2}{|c|}{$\begin{array}{c}\text { PON } \\
\left(\mu \mathrm{mol} \cdot l^{-1}\right)\end{array}$} \\
\hline & up & low & up & low & up & low & up & low & up & low & up & low & up & low & up & low & up & low & up & low & up & low & p & low \\
\hline 160 & 35.30 & 35.67 & 2 & .21 & 313 & 2346 & 064 & 126 & 51 & 222 & T. & 1.72 & 0.00 & 0 & 1 & 4.27 & 37 & 6.18 & 8.0 & 0.9 & .30 & 0.12 & 2.74 & 1.37 \\
\hline 163 & 35.30 & 35.60 & 15.47 & 14.03 & 2306 & 2337 & 2035 & 2094 & 279 & 246 & 4.03 & 3.95 & 0.23 & 0.36 & 1.88 & 3.76 & 1.43 & 3.74 & 18.5 & 13.6 & 0.34 & 0.27 & 2.95 & 2.23 \\
\hline 166 & 35.29 & 35.64 & 15.06 & 13.59 & 2308 & 2341 & 2058 & 2112 & 252 & 228 & 2.01 & 0.76 & 0.29 & 0.45 & 4.10 & 5.75 & 2.08 & 6.46 & 16.1 & 10.5 & 0.25 & 0.15 & 2.34 & 1.33 \\
\hline 170 & 35.24 & 35.64 & 16.60 & 13.83 & 2299 & 2340 & 2035 & 2120 & 267 & 224 & 1.31 & 0.89 & 0.24 & 0.53 & 1.51 & 4.71 & 1.48 & 6.80 & 15.8 & 9.6 & 0.23 & 0.15 & 2.00 & 1.51 \\
\hline 173 & 35.09 & 35.59 & 17.89 & 14.32 & 2287 & 2335 & 2015 & 2104 & 273 & 236 & 1.40 & 1.44 & 0.17 & 0.38 & 1.01 & 5.17 & 0.52 & 4.45 & 15.4 & 10.4 & 0.21 & 0.16 & 2.21 & 1.47 \\
\hline 177 & 34.87 & 35.59 & 18.62 & 14.39 & 2263 & 2333 & 2007 & 2121 & 269 & 229 & 1.34 & 1.46 & 0.31 & 0.56 & 2.26 & 5.93 & 1.85 & 6.05 & 16.6 & 10.9 & 0.23 & 0.16 & 2.21 & 1.55 \\
\hline 180 & 34.73 & 35.64 & 17.24 & 13.93 & 2261 & 2341 & 2015 & 2125 & 262 & 222 & 3.16 & 1.27 & 0.38 & 0.51 & 4.39 & 4.73 & 1.45 & 6.68 & 24.0 & 13.2 & 0.32 & 0.18 & 3.43 & 1.78 \\
\hline 184 & 35.40 & 35.70 & 15.38 & 13.41 & 2318 & 2347 & 2067 & | & 28 & 214 & 5.87 & 1.00 & 0.24 & 0.75 & 0.0 & | & 1.48 & 6.67 & 26.3 & (2. & 0.39 & 0.15 & . & 1.71 \\
\hline 187 & 35.26 & 35.66 & 15.84 & 13.74 & 2299 & 2337 & 2050 & 2125 & 265 & 221 & 2.92 & 2.02 & 0.15 & 0.38 & 1.94 & 4.38 & 1.12 & 5.77 & 19.8 & 16.4 & 0.32 & 0.21 & 3.22 & 2.30 \\
\hline 191 & 35.22 & 35.62 & 15.49 & 13.80 & 2297 & 2332 & 2071 & 2124 & 238 & 213 & 3.59 & 1.60 & 0.32 & 0.48 & 5.29 & 5.88 & 2.79 & 6.77 & 17.0 & 13.9 & 0.26 & 0.17 & 2.89 & 2.03 \\
\hline 194 & 35.53 & 35.69 & 14.89 & 13.16 & 2325 & 2340 & 2098 & 2132 & 237 & 207 & 2.43 & 0.66 & 0.42 & 0.58 & 5.78 & 6.09 & 4.41 & 8.79 & 15.4 & 10.1 & 0.23 & 0.12 & 2.48 & 1.34 \\
\hline 198 & 35.55 & 35.70 & 15.60 & 13.28 & 2324 & 2343 & 2040 & 2131 & 289 & 213 & 6.36 & 2.74 & 0.12 & 0.52 & 1.86 & 5.61 & 1.51 & 7.64 & 30.9 & 14.7 & 0.39 & 0.18 & 4.18 & 2.07 \\
\hline 201 & 35.53 & 35.69 & 16.51 & 13.82 & 2320 & 2341 & 2043 & 2127 & $\angle 00$ & 219 & 3.81 & 2.21 & 0.15 & 0.48 & 2.10 & 5.83 & 1.02 & 6.40 & 24.9 & 15.7 & 0.34 & 0.19 & 3.42 & 2.05 \\
\hline 205 & 35.45 & 35.66 & 17.48 & 14.78 & 2311 & 2338 & 2036 & 2115 & 273 & 226 & 2.94 & 1.37 & 0.14 & 0.41 & 2.64 & 6.29 & 0.95 & 5.83 & 21.5 & 13.9 & 0.31 & 0.19 & 2.85 & 1.80 \\
\hline 208 & 35.55 & 35.71 & 15.45 & 13.78 & 2325 & 2343 & 2119 & 2146 & 222 & 203 & 1.76 & 0.64 & 0.45 & 0.53 & 5.99 & 6.13 & 5.27 & 8.52 & 11.2 & 10.4 & 0.17 & 0.14 & 1. & 1.23 \\
\hline 212 & 35.56 & 35.73 & 15.57 & 13.63 & 2329 & 2347 & 2097 & 2149 & 248 & 203 & 7.30 & 1.61 & 0.31 & 0.54 & 3.28 & 6.46 & 3.27 & 8.90 & 23.9 & 12.4 & 0.37 & 0.15 & 3.22 & 1.36 \\
\hline 215 & 35.65 & 35.73 & 14.98 & 13.67 & 2333 & 2346 & 2088 & 2141 & 260 & 208 & 8.09 & 2.19 & 0.27 & 0.52 & 2.10 & 4.99 & 2.87 & 8.49 & 24.6 & 11.9 & 0.38 & 0.16 & 3.62 & 1.54 \\
\hline 219 & 35.64 & 35.73 & 16.17 & 14.34 & 2326 & 2340 & 2061 & 2125 & 278 & 221 & 3.83 & 2.70 & 0.16 & 0.43 & 1.22 & 4.05 & 1.07 & 5.51 & 21.6 & 14.5 & 0.32 & 0.21 & 3.09 & 1.97 \\
\hline 222 & 35.64 & 35.72 & 17.24 & 15.06 & 2330 & 2344 & 2053 & 2115 & 283 & 201 & 1.75 & 0.86 & 0.11 & 0.34 & 1.48 & 3.94 & 0.60 & 3.41 & 16.4 & 11.6 & 0.25 & 0.16 & 2.15 & 1.47 \\
\hline 226 & 35.58 & 35.71 & 18.18 & 14.84 & 2314 & 2342 & 2038 & 2134 & 268 & 209 & 2.00 & 0.96 & 0.10 & 0.47 & 1.81 & 6.82 & 1.03 & 5.27 & 15.6 & 10.0 & 0.29 & 0.15 & 2.23 & 1.50 \\
\hline 229 & 35.45 & 35.70 & 18.89 & 15.35 & 2294 & 2333 & 2025 & 2117 & 256 & 208 & 2.42 & 1.09 & 0.15 & 0.39 & 3.15 & 7.05 & 0.69 & 4.11 & 17.9 & 12.6 & 0.30 & 0.18 & 2.20 & 1.47 \\
\hline
\end{tabular}




\begin{tabular}{|c|c|c|c|c|c|c|c|c|c|c|c|c|c|c|c|c|c|c|c|c|c|c|c|c|}
\hline 23 & 47 & & & 82 & 97 & 34 & 57 & 35 & 38 & 196 & 77 & & 30 & & 38 & .71 & 28 & 95 & 9.9 & 10.3 & .25 & 12 & 2.89 & 24 \\
\hline 236 & .45 & 35.74 & 52 & .00 & 308 & 340 & 991 & 45 & 222 & 92 & 52 & 34 & 47 & 59| & 53 & 7.07 & 23 & 8.18 & .4 & 7.2 & 22 & 07 & .71 & .86 \\
\hline 240 & 60 & .75 & .38 & .90 & 328 & 343 & 108 & 14 & 230 & 196 & 3.08 & 0.68 & 0.37 & 0.54 & 7.76 & 6.96 & .83 & 8.00 & 20.3 & 11.1 & .26 & 10 & 14 & .36 \\
\hline 243 & 63 & .70 & .24 & 63 & 334 & 342 & 069 & 33 & 264 & 208 & 4.79 & 1.15 & .21 & 44 & .03 & 7.34 & 23 & 5.59 & 32.6 & 14.1 & .43 & .16 & .57 & 1.84 \\
\hline 250 & 5.71 & 35.76 & 14.54 & 3.74 & 2337 & 2344 & 2140 & 2149 & 221 & 203 & 1.07 & 0.43 & 0.59 & 0.60 & 8.02 & 7.25 & 8.28 & 9.42 & 11.3 & 10.1 & 0.12 & 0.09 & 1.52 & 1.16 \\
\hline 254 & 61 & .78 & 57 & .64 & 2327 & 345 & 02 & 5 & 238 & 193 & 6.40 & 0.8 & .43 & & 40 & 7.73 & 88 & 9.85 & 3.3 & 9.6 & 33 & 0.11 & .59 & .26 \\
\hline 257 & 35.66 & 35.77 & 14.57 & 3.60 & 2335 & 2347 & 2122 & 2151 & 225 & 195 & 4.44 & 1.48 & 0.50 & 0.67 & 6.28 & 7.58 & 5.68 & 9.36 & 16.4 & 10.1 & 0.26 & 0.13 & 2.84 & 1.52 \\
\hline 268 & 5.54 & 35.74 & 15.74 & 4.44 & 2314 & 2341 & 2058 & 2121 & 271 & 218 & 2.12 & 2.40 & 0.29 & 0.52 & 1.99 & 4.54 & 1.55 & 6.16 & 16.6 & 11.6 & 18 & 0.16 & 90 & 1.53 \\
\hline 271 & .56 & .73 & 15.21 & .32 & 2323 & 342 & 2100 & 13 & 231 & 206 & 2.06 & 1.0 & 0.4 & 0.53 & 3.78 & 4.98 & .74 & 7.08 & 10.6 & 9.3 & 17 & 0.12 & 1.58 & 1.26 \\
\hline 275 & 35.67 & 35.73 & 14.67 & 13.88 & 2331 & 2342 & 2125 & 2145 & 222 & 200 & 2.13 & 0.90 & 0.48 & 0.56 & 5.50 & 6.19 & 5.77 & 8.05 & 13.5 & 9.9 & 0.19 & 0.12 & 1.95 & 1.23 \\
\hline 278 & 5.62 & 35.72 & 15.10 & 4.12 & 2330 & 343 & 2094 & 2138 & 258 & 21 & 4.10 & 2.3 & 0.36 & 0.55 & 3.37 & 4.99 & 2.60 & 6.62 & 18.4 & 12.7 & 0.29 & 0.1 & 2.88 & 1.98 \\
\hline 282 & 5.65 & 35.73 & 14.62 & 4.07 & 2333 & 341 & 2108 & 131 & 238 & 208 & 3.98 & 1.48 & 0.41 & 0.53 & 4.15 & 5.36 & 4.13 & 6.92 & 18.9 & 11.5 & 0.29 & 0.17 & 2.92 & 1.71 \\
\hline 300 & 5.41 & 35.53 & 16.24 & 6.00 & 2325 & 331 & 2084 & 2095 & 237 & 232 & $1 . c$ & 1.08 & 0.2 & 0.30 & 4.07 & 4.10 & 3.4 & 3.54 & 15.6 & 11.2 & 17 & 0.13 & 77 & 1.40 \\
\hline 303 & 35.39 & 35.43 & 16.39 & 16.17 & 2322 & 2322 & 2084 & 2092 & 234 & 228 & 1.67 & 1.14 & 0.48 & 0.51 & 5.09 & 5.37 & 4.41 & 5.02 & 16.4 & 13.1 & 0.17 & 0.13 & 2.34 & 1.80 \\
\hline & 35.44 & 35.68 & 15.87 & 14.16 & 2315 & 39 & 2071 & $1 \angle 0$ & 25 & 217 & 3. & 1.56 & 0 & 0.48 & 3.79 & 5.39 & 2.83 & 6.35 & 18.3 & 11. & 0.27 & 0.1 & 2.68 & 1.59 \\
\hline std & 0.26 & 0.08 & 1.21 & 0.67 & 21 & 6 & 39 & 17 & 20 & 14 & 1.84 & 0.91 & 0.13 & 0.09 & 2.04 & 1.32 & 1.89 & 1.72 & 4.8 & 2.1 & 0.08 & 0.04 & 0.72 & 0.36 \\
\hline
\end{tabular}


Table 2. Analytical error $\left(\varepsilon_{\mathrm{D}}\right)$, vertical gradient $\left(\mathrm{C}_{\mathrm{O}}-\mathrm{C}\right)$, estimated error $\left(\varepsilon_{\Delta \mathrm{C}}\right)$ and percentage of the estimated error relative to the net ecosystem production in table $3\left(\varepsilon_{\Delta \mathrm{C}} / \Delta \mathrm{C}\right)$ for $\mathrm{O}_{2}, \mathrm{C}_{\mathrm{T}}, \mathrm{N}_{\mathrm{T}}$, phosphate, silicate, POC, PON, POP, chlorophyll a, salinity and temperature. $\varepsilon_{\mathrm{D}}$ and $\mathrm{C}_{\mathrm{O}}-\mathrm{C}$ in $\mu \mathrm{M}$ except for $\mathrm{Chl}$ a (ppb), salinity (pss) and temperature $\left({ }^{\circ} \mathrm{C}\right) ; \varepsilon_{\Delta \mathrm{C}}$ in $\mathrm{mol} \mathrm{s}^{-1}$ except for Chla (g $\left.\mathrm{s}^{-1}\right)$, salinity $\left(\mathrm{kg} \mathrm{s}^{-1}\right)$ and temperature $\left({ }^{\circ} \mathrm{Cm}^{3} \mathrm{~s}^{-1}\right)$.

\begin{tabular}{|c|c|c|c|c|c|c|c|c|}
\hline & $\mathbf{N}_{T}$ & $\mathbf{O}_{2}$ & $\mathrm{C}_{\mathrm{T}}$ & $\mathbf{P}$ & $\mathbf{S i}$ & POC & PON & POP \\
\hline & 0.05 & 0.5 & 2 & 0.01 & 0.05 & 0.5 & 0.1 & 0.01 \\
\hline
\end{tabular}

\section{Upwelling season}

$\begin{array}{lcccccccc}\mathbf{C}_{\mathbf{O}}-\mathbf{C} & 3.9 & -38 & 60 & 0.19 & 1.8 & -7.0 & -0.12 & -1.17 \\ \varepsilon_{\Delta \mathrm{C}} & 4.4 & 43.1 & 87.5 & 0.3 & 2.5 & 14.5 & 1.7 & 1.2 \\ \varepsilon_{\Delta \mathrm{C}} / \Delta \mathbf{C}(\%) & 21 & 20 & 60 & 34 & 37 & 34 & 26 & 200\end{array}$

\section{Autumn downwelling}

\begin{tabular}{lcccccccc}
$\mathbf{C}_{\mathbf{O}}-\mathbf{C}$ & 0.8 & -8.5 & 11 & 0.05 & 0.3 & -2.9 & -0.04 & -0.5 \\
$\varepsilon_{\Delta \mathrm{C}}$ & 2.8 & 28.3 & 78.5 & 0.4 & 2.0 & 19.8 & 3.2 & 1.1 \\
$\boldsymbol{\varepsilon}_{\Delta \mathrm{C}} / \Delta \mathrm{C} \mathrm{( \% )}$ & 24 & 24 & 68 & 24 & 17 & 30 & 32 & 169 \\
\hline
\end{tabular}


Table 3. Summary of the linear correlations and the regression equations $(Y=A+B \cdot X$; model II; Sockal and Rolhf, 1995) between nutrients salts consumption and oxygen, Chla and particulate organic matter production rates between consecutive sampling (3-4 days) in the Ría de Arousa during the study period. Units are $\mathrm{mmol} \mathrm{m}^{-2} \mathrm{~d}^{-1}$ (n.s., no significant)

\begin{tabular}{|c|c|c|c|c|c|c|}
\hline \multirow[t]{2}{*}{$\overline{\text { No }}$} & \multicolumn{5}{|c|}{ equation } & \multirow[t]{2}{*}{$\overline{r^{2}}$} \\
\hline & $\bar{Y}$ & \pm err Y & $\mathrm{A}( \pm \operatorname{err} \mathrm{A})$ & B ( \pm errB) & $\bar{X}$ & \\
\hline 1 & $\Delta O_{2 \mathrm{COR}}$ & \pm 44 & $27( \pm 8)$ & $-1.05( \pm 0.06)$ & $\Delta C_{\mathrm{T}}^{\prime} \mathrm{COR}$ & 0.86 \\
\hline 2 & $\Delta O_{2 \mathrm{COR}}$ & \pm 58 & n.s. & $-9.7( \pm 0.8)$ & $\Delta N_{\mathrm{T}}$ & 0.76 \\
\hline 3 & $\Delta O_{2 \mathrm{COR}}$ & \pm 61 & $38( \pm 10)$ & $-142( \pm 14)$ & $\Delta P$ & 0.74 \\
\hline 4 & $\Delta C_{\mathrm{T}}{ }^{\prime} \mathrm{COR}$ & \pm 56 & n.s. & $8.4( \pm 0.8)$ & $\Delta N_{\mathrm{T}}$ & 0.75 \\
\hline 5 & $\Delta N_{\mathrm{T}}$ & \pm 4.9 & $-3.6( \pm 0.8)$ & $15( \pm 1)$ & $\Delta P$ & 0.85 \\
\hline 6 & $\Delta N_{\mathrm{T}}$ & \pm 8 & $-5( \pm 1)$ & $1.4( \pm 0.2)$ & $\Delta S i$ & 0.61 \\
\hline 7 & $\triangle P O C$ & \pm 9 & n.s. & $6.3( \pm 0.2)$ & $\triangle P O N$ & 0.95 \\
\hline 8 & $\triangle P O C$ & \pm 18 & n.s. & $69( \pm 6)$ & $\triangle P O P$ & 0.79 \\
\hline 9 & $\triangle P O C$ & \pm 20 & n.s. & $3.0( \pm 0.3)$ & $\Delta$ Chla & 0.74 \\
\hline
\end{tabular}


Table 4. Average net ecosystem production of corrected $\mathrm{O}_{2}\left(\mathrm{~mol} \mathrm{~s}{ }^{-1}\right)$ corrected $\mathrm{C}_{\mathrm{T}}\left(\mathrm{mol} \mathrm{s}^{-1}\right)$, total inorganic nitrogen $\left(\mathrm{mol} \mathrm{s}^{-1}\right)$, phosphate $\left(\mathrm{mol} \mathrm{s}^{-1}\right)$, silicate $\left(\mathrm{mol} \mathrm{s}^{-1}\right)$, chlorophyll a $\left(\mathrm{g} \mathrm{s}^{-1}\right)$, POC $\left(\mathrm{mol} \mathrm{s}^{-1}\right)$, PON $\left(\mathrm{mol} \mathrm{s}^{-1}\right)$ and POP $\left(\mathrm{mol} \mathrm{s}^{-1}\right.$ ) for the upwelling season (June 8 to October 13, 1989). and the autumn downwelling (October 13 to 30, 1989). The average ratios between variables are show as well.

\begin{tabular}{crrrrrrrrrr}
\hline & $\Delta \mathbf{O}_{2 \mathrm{COR}}$ & $\Delta C_{\mathrm{TCOR}}$ & $\Delta N_{\mathrm{T}}$ & $\Delta P$ & $\Delta S i$ & $\Delta C h l a$ & $\Delta P O C$ & $\Delta P O N$ & $\Delta P O P$ \\
\hline Upwelling & 218 & -147 & -21.3 & -1.00 & -6.7 & 11.8 & 41.5 & 6.6 & 0.62 \\
& & & & & & & & & \\
Downwelling & -118 & 116 & 11.7 & 1.59 & 11.8 & -8.6 & -66.0 & -9.8 & -0.63 \\
& & & & & & & & & \\
\hline
\end{tabular}

\begin{tabular}{cccccccc}
\hline & $\boldsymbol{R}_{\mathrm{C}}$ & $\boldsymbol{R}_{\mathrm{N}}$ & $\boldsymbol{R}_{\mathrm{P}}$ & $\Delta N_{\mathrm{T}} / \Delta P$ & $\Delta N_{\mathrm{T}} / \Delta S i$ & $\Delta P O C / \Delta P O N$ & $\Delta P O N / \triangle P O P$ \\
\hline Upwelling & 1.48 & 10.2 & 218 & 21 & 3.2 & 6.3 & 10.5 \\
Downwelling & 1.02 & 10.0 & 74 & 7.4 & 1.0 & 6.7 & 15.5 \\
\hline
\end{tabular}





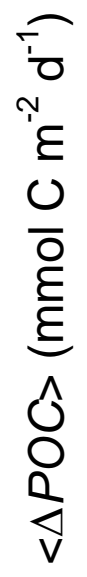

\begin{tabular}{cccc|}
\hline-200 & 0 & 200 & 400 \\
& $<N E P>\left(\mathrm{mmol} \mathrm{C} \mathrm{m}^{-2} \mathrm{~d}^{-1}\right)$
\end{tabular}




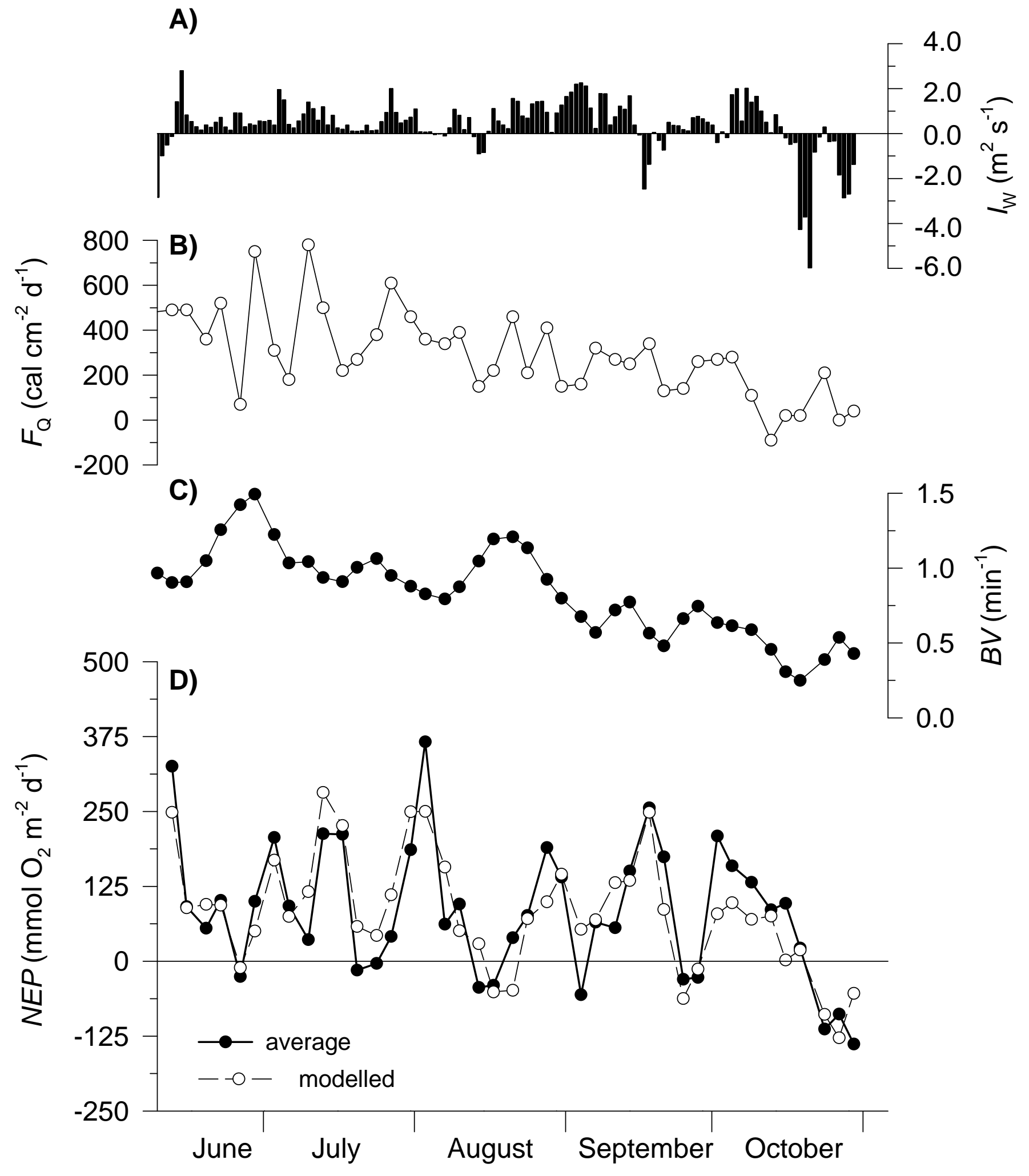




\section{Figure captions}

Fig. 1. Chart of the survey area, the Ría de Arousa (NW Spain), indicating the position of the ten sites where seawater samples were collected. The 20 and 50m isobaths are shown. Lines crossing stations $1,8,7$ and 10 are the boundaries of the study box.

Fig. 2. The 2-D box model. The study box is divided in an upper and a lower layer, separated by a level-of-no-motion, which coincides with the pycnocline. $Q_{\mathrm{x} 1}$ and $Q_{\mathrm{x} 8}$ are the surface horizontal convective flows into the study box from the Ulla and Umia estuaries; $Q_{\mathrm{X} 7}$ is the surface horizontal convective flow from the mouth of the Ría de Arousa to shelf surface waters; $Q_{\mathrm{xo1}}$ and $Q_{\mathrm{xos}}$ are the compensating bottom convective flows from the study box into the Ulla and Umia estuaries; $Q_{\mathrm{x} 07}$ is the compensating bottom flow from the shelf into the lower layer of the study box; $Q_{Z}$ and $Q_{E}$ and $M$ are the vertical convective, entrainment and turbulent mixing flows from the lower to the upper layer of the study box; $Q_{\mathrm{R}}+P-E$ is the balance of runoff, precipitation and evaporation in the study box and; $F_{\mathrm{Q}}$ the heat exchange flux across the sea surface.

Fig. 3. Time-course of (a) $\Delta C_{\mathrm{TCOR}}, \Delta N_{\mathrm{T}}, \Delta P$ and $\Delta O_{2 \mathrm{COR}}$ in mmol m $\mathrm{m}^{-2} \mathrm{~d}^{-1}$ of oxygen and (b) $\triangle P O C, \triangle P O N, \triangle P O P$ and $\triangle C h l a$ in $\mathrm{mmol} \mathrm{m}^{-2} \mathrm{~d}^{-1}$ of carbon. The linear equations in Table 3 were used to convert inorganic carbon, nitrogen and phosphorus data into $\mathrm{O}_{2}$ units and organic nitrogen phosphorus and Chla data into carbon units. The solid lines represent the average oxygen $(<N E P>)$ and organic carbon production $(<P O C>)$ obtained from the independent budgets of $\mathrm{C}_{\mathrm{T}}, \mathrm{N}_{\mathrm{T}}, \mathrm{P}$ and $\mathrm{O}_{2}$ and POC, PON, POP and Chla, respectively.

Fig. 4. Short-time-scale (3-4 days) average net production of particulate organic matter versus average net ecosystem production in the study box . Units, mmol m $\mathrm{m}^{-2} \mathrm{~d}^{-1}$ of carbon.

Fig. 5. Time-course of (a) Ekman transport, $I_{\mathrm{W}}$; (b) heat-exchange flux across the sea surface, $F_{\mathrm{Q}}$; (c) average depth-integrated Brunt-Väisälä frequency, $B V$; and $(\mathbf{d})$ average $(<N E P>)$ and modelled net ecosystem production. $B V=\sqrt{\frac{g}{Z / 2}} \cdot \ln \frac{\rho_{L}}{\rho_{U}}$, where $g$ is the gravity 
acceleration, $Z$ is the average depth of the study volume in the Ría de Arousa (23 m) and $\rho_{\mathrm{L}}$ and $\rho_{\mathrm{U}}$ the density of the lower and upper layers, respectively (Millard et al. 1990).

Fig. 6. Average (a) residual flows; (b) inorganic salts and oxygen fluxes; and (c) particulate organic matter fluxes during the upwelling season (June 8 to October 13, 1989). $Q_{\mathrm{x}}, Q_{\mathrm{xo}}$, $Q_{\mathrm{Z}}, Q_{\mathrm{E}}, M_{\mathrm{Z}}$ and $Q_{\mathrm{R}}+P-E$ in $\mathrm{m}^{3} \mathrm{~s}^{-1}$. Nutrient and organic mater fluxes in mol s $\mathrm{s}^{-1}$.

Fig.7. Average (a) residual flows; (b) inorganic salts and oxygen fluxes; and (c) particulate organic matter fluxes during the autumn downwelling (October 13 to 30, 1989). $Q_{\mathrm{x}}, Q_{\mathrm{xo}}$, $Q_{\mathrm{Z}}, Q_{\mathrm{E}}, M_{\mathrm{Z}}$ and $Q_{\mathrm{R}}+P-E$ in $\mathrm{m}^{3} \mathrm{~s}^{-1}$. Nutrient and organic mater fluxes in $\mathrm{mol} \mathrm{s}^{-1}$. 


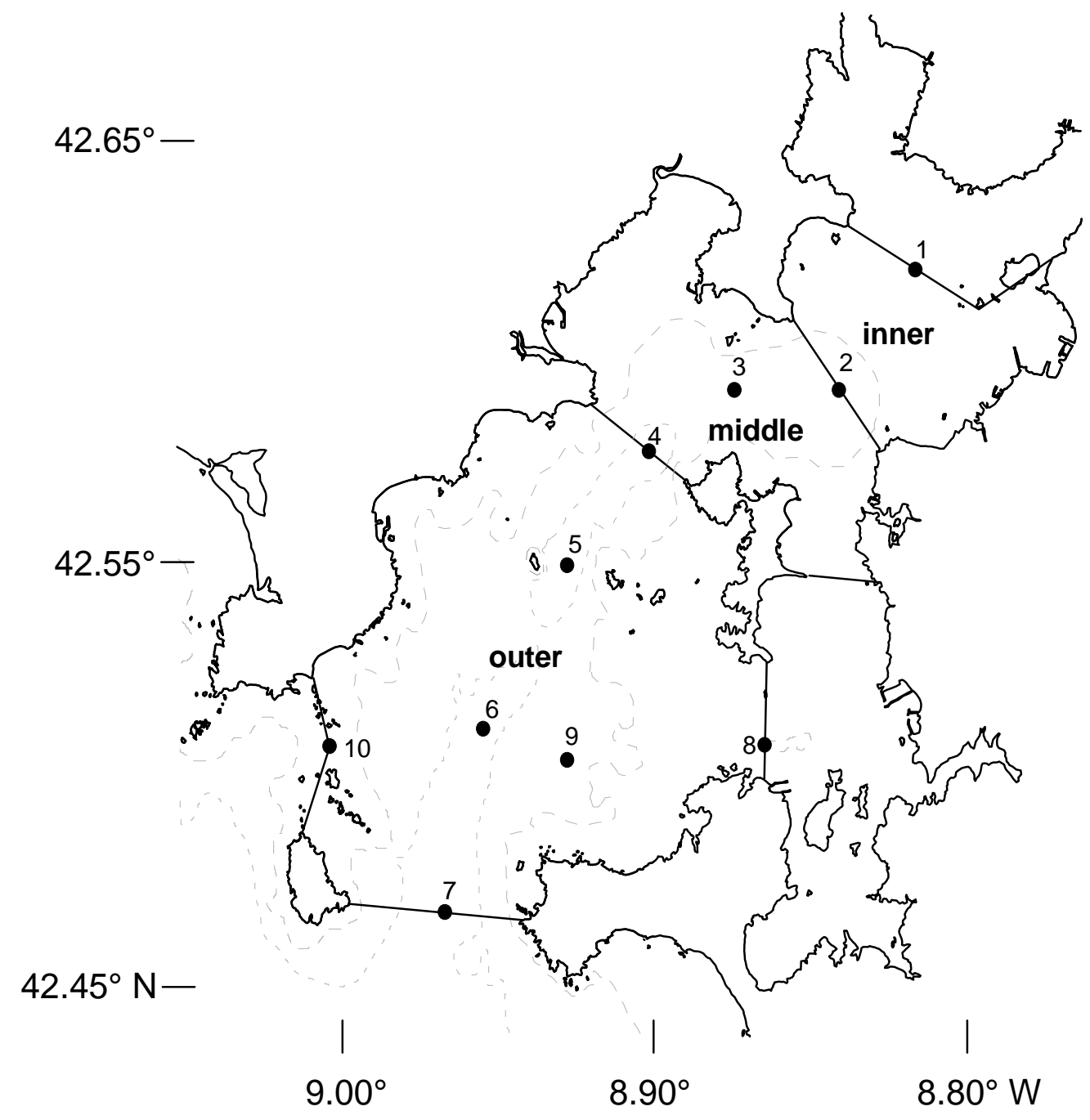




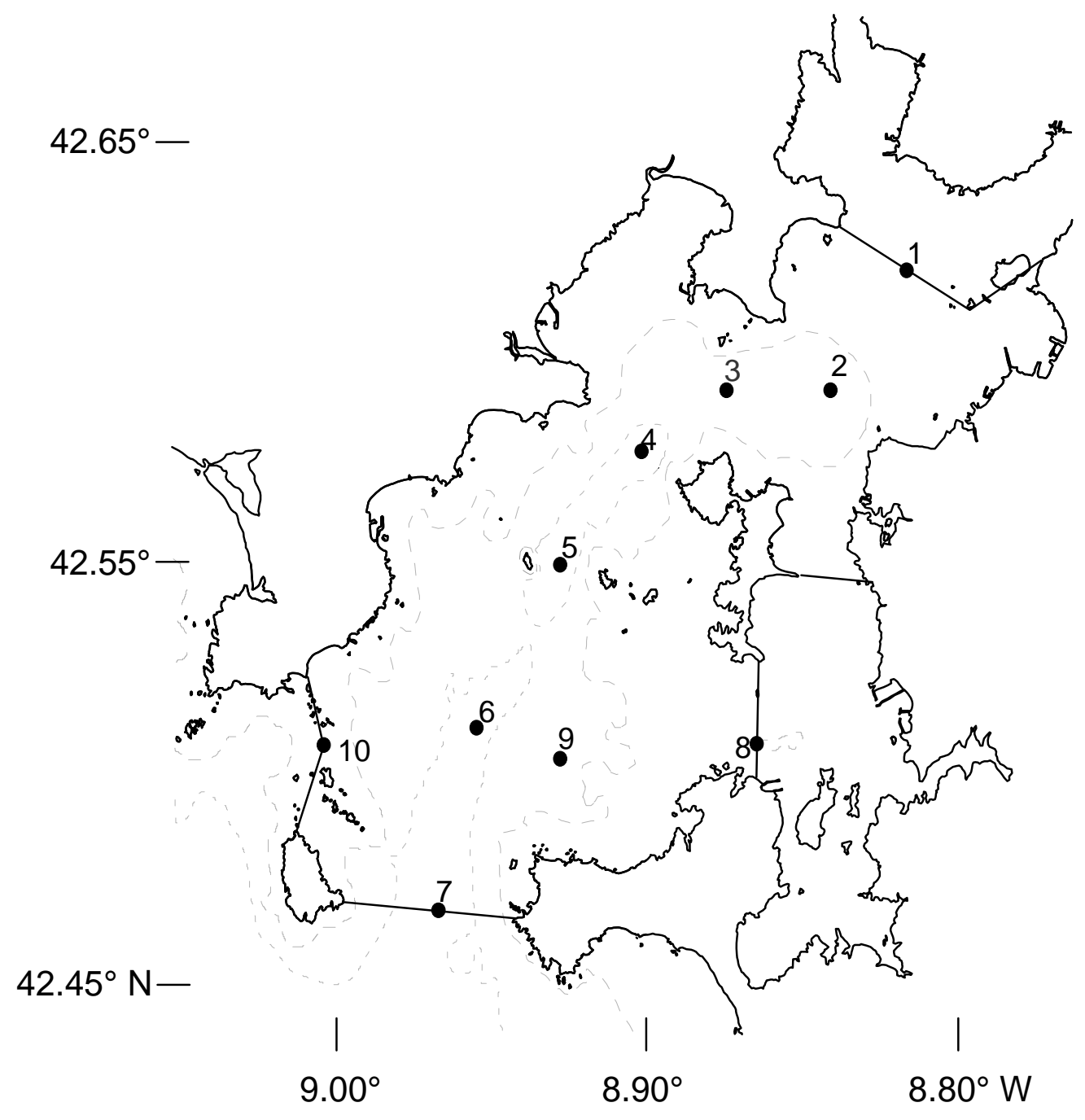



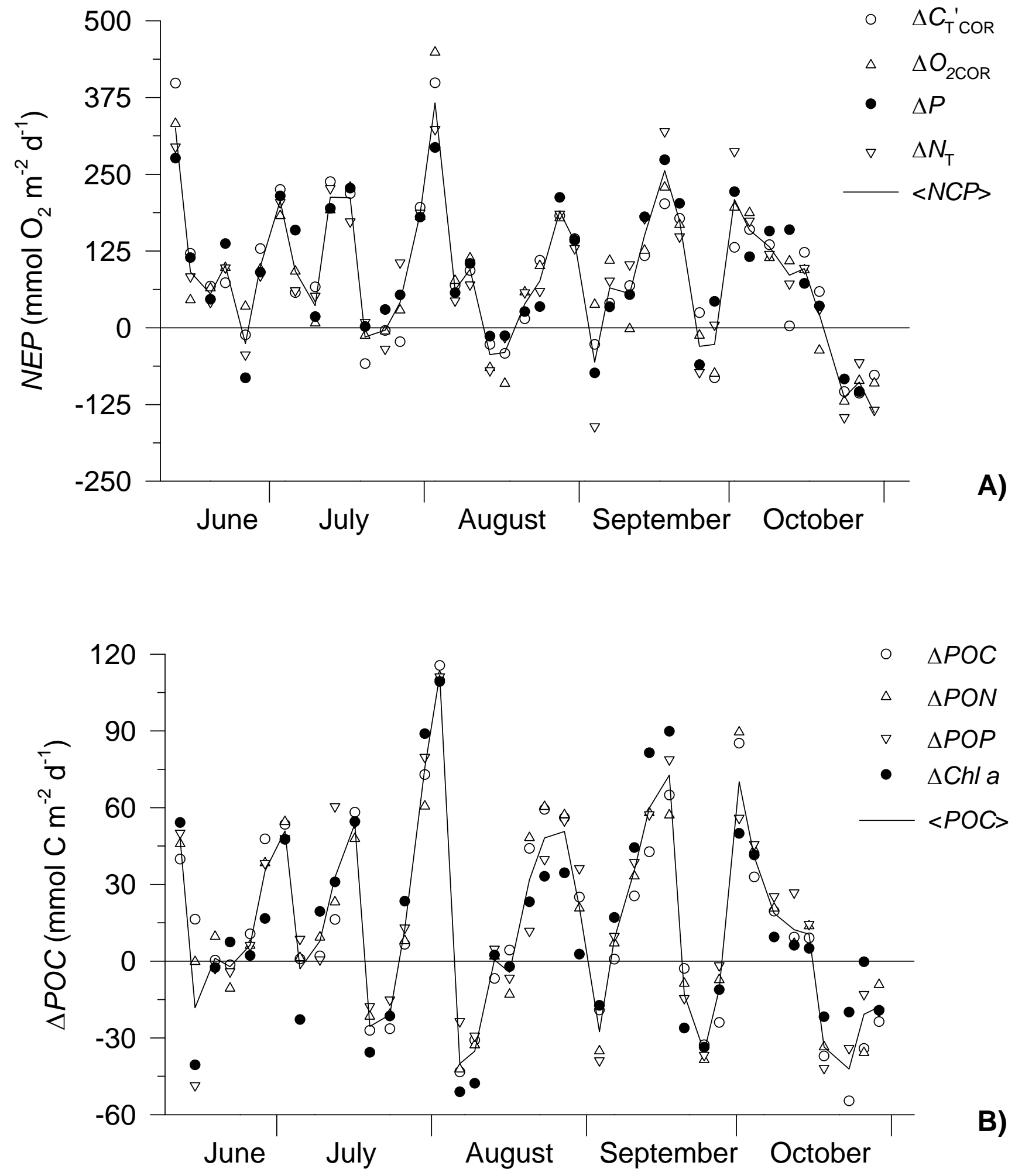


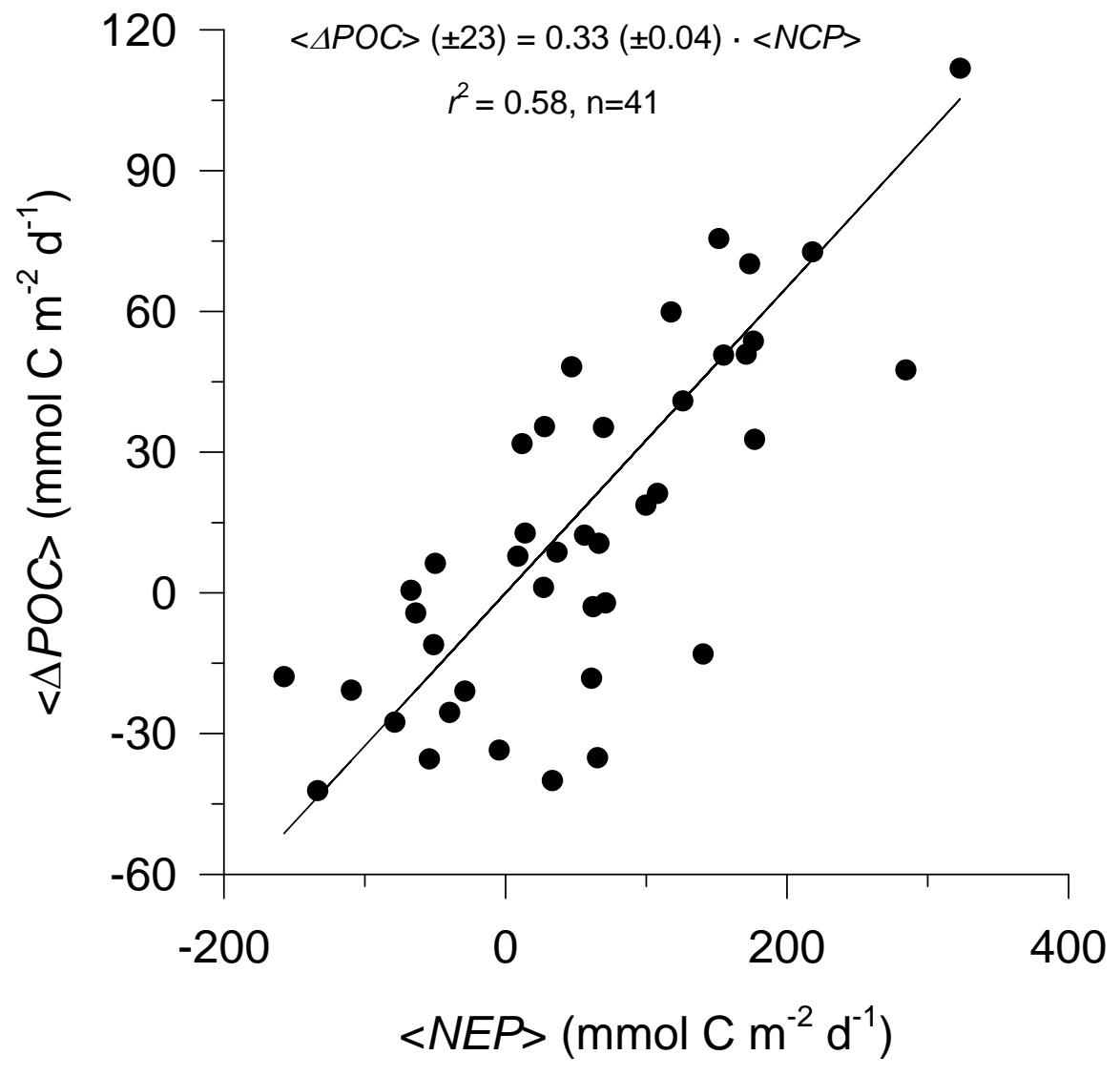




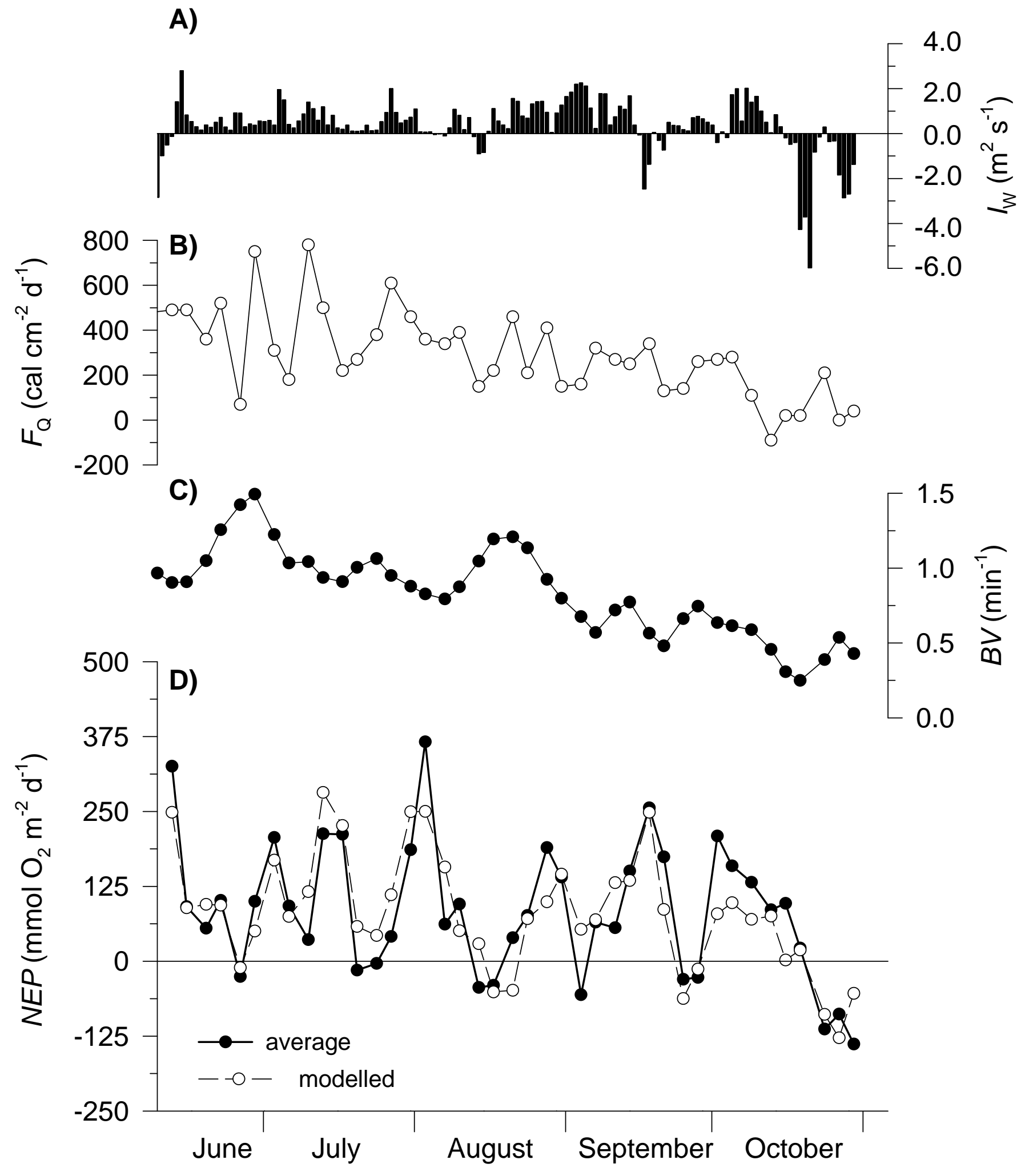



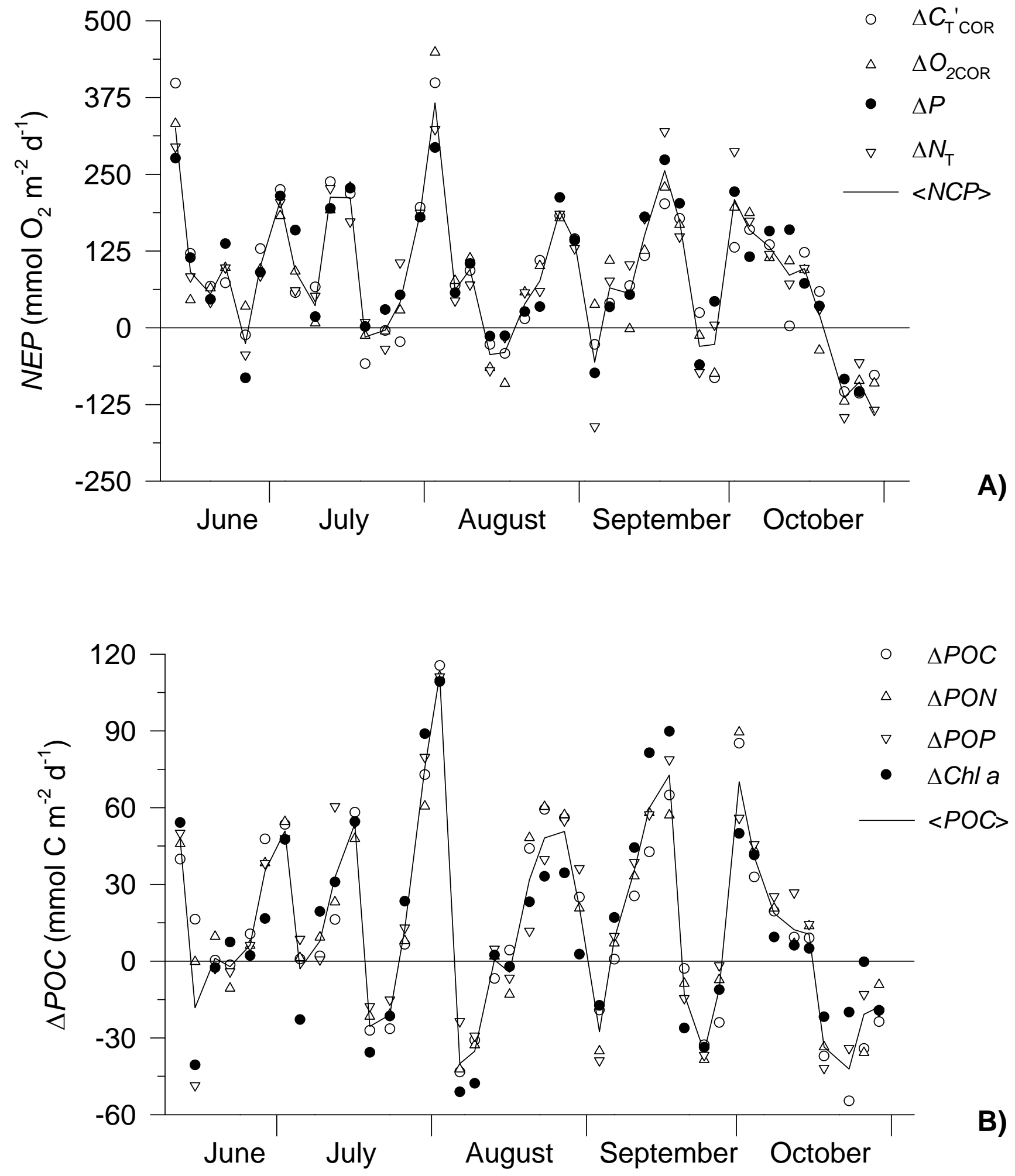


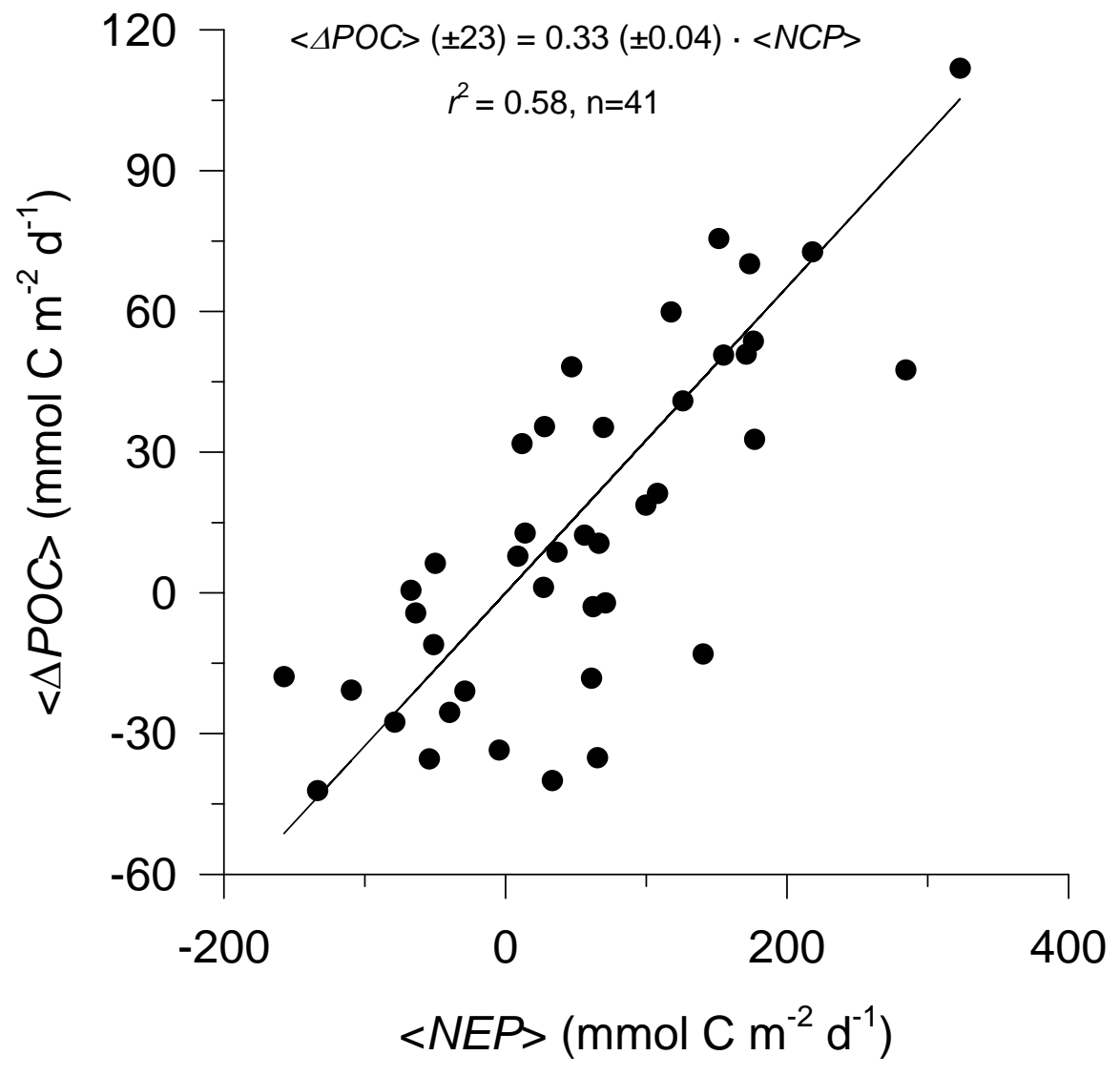




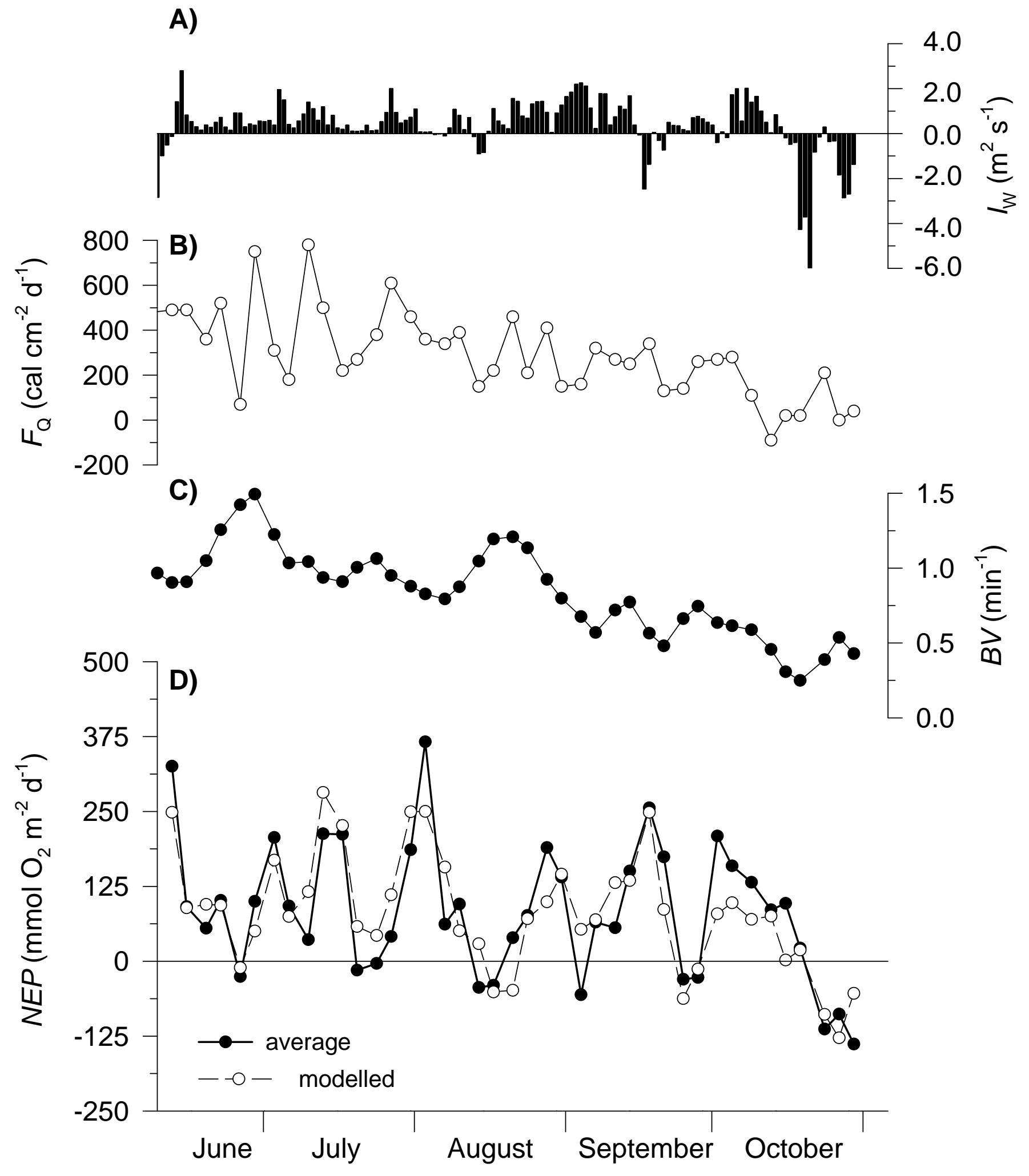

